\title{
Placas decoradas paleocristianas y visigodas de la colección Alhonoz (Ecija, Sevilla)
}

\author{
Raquel Castelo Ruano*
}

\section{INTRODUCCIÓN}

En este artículo presentamos por primera vez una historiografía dedicada a los ladrillos paleocristianos y visigodos, para después dar a conocer setenta y nueve ejemplares inéditos depositados en la Fundación Alhonoz (Ecija, Sevilla) '. Los ejemplares dados a conocer proceden de diversas provincias andaluzas (Sevilla, Córdoba y Huelva) y son producto de hallazgos casuales realizados como consecuencia de las faenas agrícolas realizadas en los numerosos cortijos de la zona. Con la publicación de estos ejemplares queremos contribuir a ampliar el corpus de estos elementos ornamentales que tanta difusión tuvieron en algunas zonas del sur peninsular. Así mismo queremos presentar algunas nuevas decoraciones que hasta el momento no se habían recogido en estudios precedentes como los realizados por Rada y Delgado, Fariña Couto o Palol, entre otros investigadores. Se alude a las iconografías representadas en las piezas para pasar a dar una interpretación funcional de las mismas.

\section{HISTORIOGRAFÍA ${ }^{2}$}

La historia de la investigación en España comienza en el año 1866 y el tema sufre vaivenes cronológicos como podremos comprobar a lo

\section{Universidad Autónoma de Madrid}

1 Queremos agradecer a D. Ricardo MARSALL, presidente de la Fundación las facilidades dadas para realizar este estudio y al Profesor U. STrLow su ayuda y consejos.

Somos conscientes de que este primer intento historiográfico puede completarse en un futuro con otras publicaciones locales de escasa difusión y a las que por el momento no hemos tenido acceso. 
largo de éstas líneas. Desde 1919 hasta 1939 no existe ninguna publicación y también transcurren nueve años desde que Schlunk en 1947 publica El arte visigodo en la serie Ars Hispaniae hasta que Palol inicia sus estudios en 1956 y los prosigue periodicamente hasta 1968, desde este año hasta 1981 existe un lapsus en el tema que se incrementa en las décadas siguientes.

En el año $1866 \mathrm{~J}$. Oliver Hurtado publica la obra Viaje Arqueológico. En ella se hace referencia a una expedición llevada a cabo por el propịo Oliver en el mes de mayo de 1864 por orden de la Real Academia de la Historia, para explorar el territorio en el que se habian producido los últimos sucesos de la guerra pompeyana. Realiza una relación sucinta de los objetos y datos obtenidos en el viaje. Entre estos objetos menciona dos ladrillos cristianos: uno procedente de Puente Genil y otro de Osuna. Con respecto al primero especifica que fue encontrado en el paraje denominado «Los Arroyos»; y lo describe en los siguientes términos: «tiene de relieve el monograma de Cristo en medio del alfa y el omega y la siguiente inscripción «Felix Asella», del que acompaño calco $n$. $^{\circ}$ » (1866, pp. 42-43). El segundo ejemplar lo encontró en el Gabinete de Antigüedades, propiedad del Sr. D. Domingo Silos Estrada «reputadísimo jurisconsulto de Osuna y persona de gran ilustración y aficiones arqueológicas». Realiza la siguiente descripción: "ladrillos con inscripción en sus cantos donde se lee «Chioni Vivas» y el monograma de Cristo vuelto también de derecha a izquierda precediendo, en tal sentido, a aquella fórmula invitatoria» (1866, pp. 57-58).

En 1869 A. Hübner publica Inscriptiones Hispaniae Latinae. Volumen Secundum. Bajo el epigrafe Instrumenti Domestici. Tegulae recoge los siguientes ejemplares: 4967.32 Piezas halladas en llipa (en el lugar conocido como Los Llanos); en Sevilla (en un sepulcro encontrado en el Huerto del Palacio de San Telmo); en Astigi y los conservados en la colección de Nathanem Wheterel y en el Museo Arqueológico Nacional procedentes, seguramente de yacimientos de la Bética. Se lee «Bracari vivas cum tuis». 4967.33 Ejemplar de la Huerta de Argamasilla, a menos de media legua de Adamuz (Córdoba), hacia el Carpio. Se lee "Camilla in deo decedit e vita». 4967.34 hallado también en Adamuz. Se lee "Cawlates in Deo. Crismón. Les hecce annus». 4967.35 ejemplar conservado en la colección de D. Domingo de Silos Estrada. Se ha realizado un crismón y la inscripción "Chioni vivas» escrita de derecha a izquierda. 4967.36 Procede del paraje denominado Los Arroyos (Puente Genil). Se lee la inscripción «Felix Asella» y un crismón con alfa y omega; ejemplar citado por Oliver y 
Hurtado en 1866. 4967.37 procede de la Huerta de los Aldabalones (Córdoba). 4967.38 Ladrillo conservado en el Museo Bernardo Gamez de Cabrera, posteriormente de Leonardo Cevallos. Se lee «Ex. off. Leonti» y en medio se ha representado un crismón. 4967.39 Dos ladrillos del Palacio de los Duques de Fernán Nuñez. Fueron encontrados en 1855 en la posesión conocida como Plantanar. En ellos se puede leer: 1.- «Ex. off. Leonti» y 2.- «Merc». 4967.40 Ladrillos encontrados en el Olivar de Pero Alonso de Castro, cerca de la Fuen Blanquilla (Bujalance, Córdoba). En ellos se puede leer: "Marciane vivas in Christo" y "Spes in Deo" (1869, p. 663).

Este autor dio a conocer, en 1892, Corpus Inscriptionum Hispaniae Latinorum. Supplementum. En el apéndice dedicado a Instrumenti Domestici.Tegulae. Recoge los siguientes ejemplares: 6253.1 Dos ejemplares del Cortijo de Carija, cerca de Bornos. Se lee «Aelia El[e]na cum filis gaudet Subu[le] sal(va) y crismón en el centro con alfa y omega encerrado en un círculo. 6253.2 Ladrillo conservado en la Colección Caballero Infante. Procede de Sevilla. Se lee «Diona cum filis W». 6253.3 Diversos ejemplares de Sevilla conservados en la colección Caballero Infante. 6253.4-10 ladrillos conservados en el Museo Arqueológico Nacional de Madrid. Presentan varias inscripciones. 6253.11 Pieza hallada en Acinipo (Ronda la Vieja) conservado en la Colección Caballero Infante. Se lee «Flav(i) Demetriani». 6253.12-14 piezas conservadas en el Museo de Córdoba. Presentan varias inscripciones (1892, pp. 1.007-1.008).

En 1876 Juan de Dios Rada y Delgado da a conocer en Museo Español de Antigüedades el artículo «Ladrillos sepulcrales cristianos que se conservan en el Museo Arqueológico Nacional. Publica tres ejemplares. El primero conservado en el Gabinete de la Real Academia de la Historia con un vaciado en el Museo Arqueológico Nacional. Fue adquirido por D. Tomás Muñoz y Romero, miembro de la Academia de la Historia y Catedrático de la Escuela de Diplomática, en el mercadillo del Rastro de Madrid; nunca pudo averiguar su procedencia. Halló paralelos en el Gabinete de Nathanem Wheterell, vecino de Sevilla y en el obispado de Málaga. El tipo iconográfico corresponde a fachada arquitectónica que cobija un crismón con Alfa y Omega e inscripción BRACARI VI/VAS CUM TUIS». Rada y Delgado considera que estas piezas pertenecerían a «diversas personas de una misma familia, cuyo patronímico sería BRACA$\mathrm{RIO}$, nombre que no aparece en inscripciones romanas del paganismo" 0 a algún otro personaje «tenido en concepto de santidad y al cual se pusiese en diferentes lugares tal dedicatoria». Sin embargo no encontró a 
ningún personaje célebre con este nombre ni en los primeros tiempos del cristianismo ni en época visigoda (1876, pp. 593-594); ladrillos con la misma inscripción fueron mencionados por Hübner en 1869. El segundo ladrillo citado por Rada procede de la Colección Caballero Infante y fue adquirido por el Museo Arqueológico Nacional; se conoce su lugar de procedencia: Espejo (Córdoba).

Las piezas citadas tendrían, según este investigador una cronología que abarcaría desde finales del siglo $v$ y principios del siglo vı. Con respecto a su funcionalidad cree que podrían haber servido como cubierta de los «loculi o sepulcros cristianos». Se basa en un texto de la obra Conversaciones Histórico-Malagueñas (1790). Descanso II En la villa de Benjoan, Vicaria de Ronda, se encontró, a media legua de ella en 1772 en el sitio que llama las Viñas del Concejo, un sepulcro cristiano, como lo indica su inscripción excavada en un ladrillo de dos cuartas de larga y una de ancho, cuya copia es como sigue y su lectura es: «Aquí está sepultado Bracario con los suyos. A seguida pone un grabado en madera copia del ladrillo: crismón en el centro Alfa y Omega, fajas verticales. Leyenda. Carece de columnas y el arco es angrelado adornado con hojas en curva y flores cuadrifolias en las enjutas» (1790, pp. 301-302).

En 1906 L. Siret en su obra monográfica Villaricos y Herrerias. Antigüedades púnicas, romanas, visigóticas y árabes. Memoria descriptiva e histórica, cita el hallazgo de un ladrillo en la casa $n .^{\circ} 4$ del Cerro de Montroy (Almería). La pieza estaba decorada con impresiones hechas con dedos junto a platos y fuentes de Terra Sigillata Hispánica Tardía. El Cerro de Montroy presenta en su cima construcciones domésticas fechadas en época árabe, el resto de la elevación presenta edificaciones de un período que abarca desde la caida del imperio romano hasta la invasión árabe. Para la cimentación de las casas se aprovechó la pizarra (característica de la zona) y para el alzado de los muros piedras y barro. Alguna vivienda tenía el suelo de hormigón y las paredes presentaban enlucido de yeso. El piso suele estar cubierto de escombros que proceden de la destrucción de las paredes y los techos; a veces éstos alcanzan los $3 \mathrm{~m}$. de espesor. El autor comenta que algunos ladrillos semejantes al hallado en la casa $n .^{\circ} 4$ se encuentran en las paredes de las sepulturas visigóticas (1906, p. 62).

En $1908 \mathrm{~F}$. Fita da a conocer el estudio «Inscripciones romanas y visigóticas de Tarifa, Ronda y Morón de la Frontera", Boletín de la Real Academia de la Historia. En la ciudad de Ronda aparece un ladrillo con la siguiente inscripción «BRACARI VIVAS CUM TUIS» que transcribe como 
«Bracario vivas con los tuyos". Identifica este nombre con el de dos o tres obispos de la Bética, considerándolo común a diferentes personas. Fita alude a una lápida sepulcral procedente de Mérida y recogida por Hübner en donde también aparece reflejado el nombre Bracario: «BRACARIUS FELIX VIXIT ANNOS LII; RECESSIT NONAS APRILES ERA CCCCXVIIII» (Bracario Felix vivió cincuenta y dos años, pasó de esta vida el cinco de abril de la era 419 (año 381). Considera que el vocablo Bracarius es un nombre común, puro romano y de origen céltico. En principio comprendía los oficios de sastre y zapatero para posteriormente ser nombre propio de persona $(1908,351)$. En la localidad de Morón de la Frontera cita otro ejemplar de ladrillo decorado descubierto en el año 1897 en el Cortijo de Barbuan. Reseña que la leyenda "SALVO EPISC(o)PO MARCIANO", está bastante bien conservada y la fecha en el siglo IV. Identifica a este personaje con un obispo de Sevilla de finales del siglo iv y comienzos del siglo $\checkmark(1908,353)$.

En 1909 M. Rodríguez Berlanga publica Catálogo del Museo Loringiano. En relación al período cristiano y en el apartado dedicado a Inscripciones; cita los siguientes ejemplos de placas decoradas: Córdoba.Ladrillo procedente de la Huerta de los Aldabones: "se descubrió uno con diferentes adornos en alto-relieve y en medio el Chrisma teniendo encima y debajo dos grupos de letras que lee el profesor Hübner GLAUCl y yo GILI/AUC (1909, pp. 126- 129). Ronda.- Cita dos ejemplares. Los describe de la manera siguiente: «en uno de cuyos lados mayores hay estampado un arco sostenido por dos columnas; en el centro Alfa y Omega primera y última letra del alfabeto griego a ambos lados del anagrama de Cristo representado por las tres consonantes: $\mathrm{X}, \mathrm{P}, \mathrm{T}$, con que se escribía en griego este nombre que significa Ungido. A la derecha y a la izquirda del mencionado arco aparece verticalmente escrita esta leyenda: Bracari vi/vas cum Tuis. Bracario ojalá vivas con los tuyos» (1909, p. 130). Casablanca (Málaga). «Fragmento de ladrillo encontrado en tierras del Cortijo de Casablanca a cuatro leguas de Málaga, al hacer la explanación del ferrocaril de Córdoba a dicha ciudad. En una de sus caras mayores aparece grabado dentro de una corona de pequeñas hojas el Chrisma, es decir el monograma de Cristo acompañado del Alfa y el Omega, pero tanto el dicho monograma de Cristo como las letras mencionadas grabadas de derecha a izquierda: Chrisma (en sentido inverso)» (1909, p. 130, lám. $X X X I X)$.

En el año 1911 E. Romero de Torres da a conocer en el Boletín de la Real Academia de la Historia, el estudio titulado "Montilla romana y visi- 
goda. Nuevos descubrimientos". A través del Sr. Algaba tuvo conocimiento de la aparición de una sepultura y dos ladrillos con «inscripciones y labores", en la finca conocida como Pozo Techado, situada al suroeste de Montilla y propiedad de D. Francisco Alvear, Conde de la Cortina. El hallazgo se produjo de forma casual al hacer una plantaciones de olivos. Hace la siguiente descripción: «Miden $0,33 \mathrm{~cm}$. de alto $\times 0,28$ de ancho. Son de barro cocido y completamente iguales. Sus inscripciones están compuestas de letras y siglas invertidas; en sus centros ostentan dentro de un filete circular el monograma de Cristo; en los ángulos respectivos tiene cuatro adornos resaltados de curva biselada cuyos extremos se enroscan a manera de volutas; dentro de éstos se ve un ciprés y a derecha e izquierda del crismón ofrece un exorno formado por pequeños botones que afectan la forma de piña o racimo a base paralela a ambos costados. El tipo de las letras y de los símbolos no es anterior al siglo $v$ ni posterior al vi. Aparece el nombre CILAUCl interpretado como (Fábrica) de Cilauco" (1911, p. 78). Señala como paralelos: el ejemplar hallado en la Huerta de los Aldabones, una pieza del Museo Arqueológico de Córdoba del que se desconoce su procedencia aunque se ha pensado que fuese encontrado junto a otras piezas en Puente Genil. El autor se plantea la posibilidad de que las inscripciones fueran marcas o nombres del fabricante cristiano. Señala que la finalidad de éstas piezas no está muy clara pero se inclina a pensar en un carácter funerario (1911, pp. 75-81).

Gcho años después, E. Romero de Torres da a conocer el artículo «Nuevos descubrimientos arqueológicos en la provincia de Córdoba» en el Boletín de la Real Academia de la Historia. Señala que a través de D. Manuel Baena, tuvo conocimiento del descubrimiento en un huerto de la aldea denominada El Hoyo, a ocho kilómetros al sur de Bélmez (Córdoba) de: «muchos ladrillos de barro cocido decorados con diferentes labores y letras en relieve». El estado de conservación era muy malo pero se pudieron distinguir dos tipos:

1. «Hombre a caballo con el torso inclinado hacia a trás y su escudero o criado a pie delante del corcel en actitud de sujetarlo del diestro. Toda la decoración se encierra en un rectángulo cuadrado sobre el que corre una inscripción en caracteres latinos que dice «EDIFICAT» (Edifica) y al final de la misma hay un adorno en forma de $X$ para rellenar el espacio comprendido entre la última letra y la línea del recuadro. Dimensiones: $0,27 \mathrm{~m}$. de alto y $0,33 \mathrm{~m}$. de ancho". Lo compara con cinturones de época visigoda fechados en los siglos $v$ y $v 1$ depositados en el Museo Arqueológico Nacional $(1919,135-136)$. 
2. "Dentro de un rectángulo cuadrado un círculo en cuyo centro se ven dos palomas enlazadas en forma de cruz, uniéndose a la línea de la circunferencia los vástagos de cuatro hojas de yedra o de corazón y el espacio que media entre cada una de ellas está ornamentado con pequeños adornos semejantes a una estrella o flor cuadrifolia". Tras realizar la descripción de la pieza pasa a interpretar la simbología de los elementos representados. Las palomas cruzadas representan al Amor Divino y Eterno; las hojas de yedra simbolizan el Amor Terrenal que nace de áquel y la unión de ambos amores trae como consecuencia el amor humano con el amor con Dios $(1919,138)$. Junto a los hallazgos de la aldea del Hoyo cita otro ejemplar hallado entre varios restos constructivos en el Cortijo conocido como Los Libros, en este caso a catorce kilómetros de Córdoba y en su término Municipal y a la izquierda de la carretera de Madrid a Cádiz. La propiedad pertenecía a D. Antonio Pineda de Las Infantas, ex-alcalde de esta población y Vicepresidente de la Comisión Provincial. El ladrillo se caracteriza por: «medir $28 \mathrm{~cm}$. ancho. Barro cocido duro y compacto. Composición en relieve sencillo y elegante dentro de una moldura cuadrángular se desarrolla un motivo decorativo en forma de cruz» (1919, 138). Con respecto a la funcionalidad propone dos posibilidades; no se inclina por ninguna de ellas: a) que sirvieran para cubrir las sepulturas y b) que fueran elementos ornamentales de recintos sagrados y estuvieran colocados en los muros (zócalos o frisos) o bien en los pavimentos (1919, 139-140).

En 1939 L. Fariña Couto publica en el Boletín del Seminario de Arte y Arqueología de Valladolid «Notas sobre los motivos ornamentales visigóticos. El ladrillo con relieves». Estableció dos grupos atendiendo a los motivos ornamentales que presentaban:

1. Empleo exclusivo de temas ornamentales geométricos. Incluye las baldosas de Burguillos (Badajoz); un ejemplar conservado en el Museo Arqueológico Nacional de procedencia desconocida; un ejemplar de la Facultad de Filosofía y Letras de Sevilla, también de procedencia desconocida y otro de la Colección Volckers del que igualmente se desconoce su procedencia.

2. Decoración figurada. Para este grupo distinguió tres categorias: 2a.- Ladrillos en lo que se introducen símbolos o representaciones cristianas de los primeros tiempos del cristianismo (palomas, delfines, etc...). Se conocen dos de procedencia andaluza, sin especificarse nada más y otro procedente de la Academia de la Historia. 2b.- Ladrillos con el monograma 
constantiniano. Cita diez ejemplares procedentes de varios yacimientos y colecciones: Huerta de los Aldabones (Córdoba); Museo Arqueológico de Córdoba (1940, 207, lám. VI); Laboratorio de Arte de la Facultad de Filosofía y Letras (1940, p. 207, lám. VIII); Morón de la Frontera (Sevilla) conservado en la Hispanic Society of New York (1940, 208, lám. IX); Gabinete Arqueológico de la Real Academia de la Historia (1940, 208, lám. X). 2c.- Ladrillos con temas del Antiguo y Nuevo Testamento, por ahora solo documentados en Túnez y depositados en el Museo del Bardo (Adán y Eva, p. 209, lám. XI; sacrificio de Isaac, p. 209, lám. XI.2; Jesús y la samaritana, lám. XII.1 y Virgen con niño, lám. XII.2). Con respecto a su funcionalidad considera que la industria cerámica tuvo una gran importancia como medio ornamental de las construcciones (1939-40, 205-210).

En 1940 E. Camps Cazorla publica en la Historia de España dirigida por Ramón Menéndez Pidal «El arte hispanovisigodo». En relación con el foco cordobés alude a ejemplares de ladrillos estampados con motivos ornamentales a bisel, ejemplares que fecha en el siglo $\vee$ d.C. y que considera pudieron tener alguna utilización de carácter sepulcral.

1. Ejemplar procedente de Acinipo (Ronda la Vieja). Conservado en el Museo Arqueológico Nacional. Decorado con un arco sobre columnillas que cobija un crismón y en sus lados lleva una inscripción con una exclamación de claro sentido funerario: BRACARI VI/VAS CUM TUIS;

2. Dos piezas procedentes del Museo Arqueológico Nacional que también tiene representado el crismón con las mismas decoraciones.

3. Pieza conservada en el Museo Arqueológico Nacional con decoración de círculos secantes dentro de otro mayor y una inscripción invertida con su correspondiente crismón en su parte alta.

4. Ejemplar decorado con un marco de hojas lanceoladas, en cuyo centro se inserta un lazo cuadruple de claro «estilo norteño».

5. Pieza del Museo de Córdoba con dos grandes rosetas dentro de marcos de triangulillos (1940, pp. 477-478).

En ese mismo año J. Ferrandis da a conocer en el mismo tomo de la Historia de España dirigida por Ramón Menéndez Pidal «Artes decorativas visigodas». Dentro de este apartadio incluye un epígrafe sobre la cerámica y en él cita los ladrillos a los que considera elementos funerarios que formaban parte de las sepulturas. Recoge algunos ejemplares:

1. Ladrillo procedente de Montroy (Almería), citado por Siret y decorado por dos series de líneas onduladas cruzadas en aspa. 
2. Ladrillos procedentes de Ronda y Cártama decorados con un gran crismón central y leyenda "Bracari vivas cum tuis».

3. Pieza procedente de Valencia con decoración estampada integrada por una cruz patada central con una serie de hojas estilizadas a su alrededor.

4. Ejemplares procedentes de Burguillos (Badajoz). En este último caso se emplearon dos series de ladrillos: unos de forma romboidal con motivos cruciformes y vegetales estilizados que arrancan de pequeños círculos o rombos centrales y otros de tiras estrechas y delgadas con follaje ondulante, que servían de separación a la serie principal (1940, p. 656).

En 1941 M. Esteve Guerrero publica en la serie Actas de la Sociedad de Antropología, Etnologia y Prehistoria. Atlantis "Contribución al conocimiento de Asta Regia». En este estudio cita un ladrillo como procedente de Asta Regia, al que él considera de carácter funerario, que durante un tiempo estuvo en posesión del pintor de Jerez J. Rodríguez Losada. El ejemplar, cuyo paradero desconoce, presentaba la leyenda BRACARI VIVAS CUM TUIS y un crismón central; era semejante a otros hallados en Ronda. En la nota $n .^{\circ} 30$ Esteve Guerrero hace la siguiente aclaración: «En Ronda, en el llamado Museo de los Baños Arabes de las tenerías existen varios de estos ladrillo, que según comunica el Profesor Martínez Santa-Olalla son falsos, como casi todo lo que allí se expone. Tales ladrillos muy abundantes, en el British Museum hay uno, llevan la "Chi" y la "Rho" en la forma constantiniana con al "Alfa" y el "Omega" franqueándoles» (1941, p. 41).

J. Vives en 1942 publica la obra Inscripciones cristianas de la España romana y visigoda, en el apartado dedicado a Inscripciones no sepulcrales. Tejas y ladrillos, recoge cuatro ejemplares:

1. «BRACARI VI / A X W VAS CUM TUIS». Señala que existen numerosos ejemplares conservados en varios lugares de la Bética. Cita Hübner, 193; Fita, Boletín 53, 1908, 325, foto; Diehl, 864 (1942, 138, n. $\left.{ }^{\circ} 406\right)$.

2. "SALVO EPIS (c.) A X W MARCIANO». Procede de Morón. Considera a Marciano obispo de Astigi (Ecija) al haber encontrado un personaje con este nombre para los años 629-638. Cita a Hübner 437, Fita Boletín 53 (1908), 353 foto, Diehl 915 (1942, p. 139, n. ${ }^{\circ}$ 409).

3. «LENTENTUR CELI ET/EXULTET TERRA OMN". Hallado en Villaviciosa de Córdoba (Córdoba). Especifica que es un ladrillo visigótico 
tosco con inscripción en grafito. Identifica la frase con "un texto de Paralipom 16, 31 y del Salmo 95,11 pero sin el omn(is). Con este texto comienza la Misa de Pascua de Resurreción en el Misal mozárabe. Cita a Romero de Torres, boletín 74 (1919), 375, 77, foto (1942, p. 110, n. $\left.{ }^{\circ} 415\right)$.

4. «EDIFICAT X(ps)/ Hombre a caballo y criado a pie. Procede de Bélmez (Córdoba). Especifica que las letras están al revés y son algo imprecisas. Señala que la restitución $X(p s)$ está realizada por él y la considera probable. Cita Romero de Torres, Boletín 74 (1919), 135. 140 foto (1942, p. 140, n. $\left.^{\circ} 416\right)$

H. Schlunk en 1944 publica «El arte decorativo visigodo" en el Boletín Bibliográfico considera a los ladrillos de barro cocido uno de los grupos más peculiares de monumentos del sur de España. Cree que debieron servir, principalmente, de exvotos, funcionalidad sugerida por primera vez. Cita la existencia de dos talleres: el primero localizado cerca de Ronda, hallazgo que conoció a través de D. Félix Hernández Jiménez (vecino de Córdoba) y que ya citó en una nota de su Tesis Doctoral ${ }^{3}$ presentada en Berlín en 1930 y publicada seis años más tarde y el segundo ladrillo situado en las cercanias de Granada, citado por el Sr. Gómez Moreno en su obra Monumentos arquitectónicos de España. Granada.

Schlunk cree que los motivos ornamentales geométricos que decoran estas piezas derivan de los dibujos representados en los mosaicos. Cita algunos ejemplares:

1. Ladrillo procedente de Mallorca decorado con una estrella de seis puntas. Señala como paralelo un ladrillo procedente de Sbeitla (Túnez), actualmente en el Rijksmuseum Van Oudheiden en Leyden. Plantea dos posibilidades que el ejemplar español haya sido fabricado en las Baleares con arreglo a un modelo semejante o bien que haya sido importado del Norte de África (hipótesis por la que acaba inclinándose).

2. Quince piezas procedentes del taller de Ronda.

3. Varios ejemplares con la representación de un crismón debajo de un arco o dosel procedentes también del taller de Ronda.

4. Ladrillo decorado con trenza de cuatro cintas enlazadas con gruesos nudos insertados en los puntos de enlace de las cintas. El marco está

3 Die Ornamentik in Spanien zur Zeit der Herrschaft des Westgoten, Berlín, p. 65. Nota 91. 
constituido por hojas en forma de lancetas según las tallas a bisel (1944, 17-19).

En 1947 publica «Arte visigodo. Arte bizantino» en Ars Hispaniae. Historia Universal del Arte Hispánico. Dedica un apartado a la escultura visigoda en donde se incluye una breve referencia a los ladrillos estampados con motivos decorativos en talla a bisel. Plantea dos funcionalidades: revestimiento de las sepulturas o exvotos. Considera que el origen de estos elementos ornamentales se encontrarían en el Norte de África, concretamente en la región tunecina y que posteriormente se fabricaron, en grandes cantidades, en Andalucia. Con respecto a la cronología propone que la mayoría de los ejemplares documentados podrían fecharse entre los siglos IV y $\vee$ y cree que es dificil fijar con exactitud hasta que época siguieron en uso, propone los siglos Vi y vII. En relación a la decoración se da cuenta que mientras en el Norte de África predominan los ejemplares ornamentados con animales, figuras humanas e incluso religiosas, en España prevalecen los derivados con dibujos geométricos y símbolos cristianos (crismones, palomas, cráteras, pavos reales, delfines, etc.) (1947, p. 235).

P. Palol en el coloquio Settimane di Studio del Centro Italiano di Studi sull'Alto Medioevo.III. I Goti in Occidente. Problemi, celebrado en 1956 publicó «Esencia del arte hispánico de época visigoda: romanismo y germanismo". Realizó una breve referencia sobre los ladrillos: considera a los ejemplares procedentes de hallazgos andaluces y baleáricos de corriente Africana. Cita el taller de Ronda y otro en los alrededores de Granada. Señala que los ejemplares aparecen especialmente en las provincias de Córdoba, Sevilla, Cádiz y Mérida (1956,87-88).

En 1958 Santos Gener publica en el Boletín de la Real Academia de Córdoba de Ciencias, Bellas Letras y Nobles Artes «Las artes en Córdoba durante la dominación de los pueblos Germánicos». Con respecto a las "baldosas decorativas» señala que la decoración cerámica aplicada a la arquitectura es frecuente desde tiempos muy antiguos y se remonta al mundo etrusco. Distingue la existencia de dos tipos de ladrillos según su funcionalidad: 1) para decorar los techos (conservarían los orificios para pasar los clavos que los sujetaban a las armaduras de madera de la techumbre o presentarían las líneas de encaje como tabicas de techo); 2) para ornamentar las paredes (presentarían los dorsos estriados para que la mezcla de cal u hormigón las adherieran firmemente al muro) (1958, 147-192). 
Un año despues, 1959, A. Recio y C. Fernández Chicarro publican en el Boletín del Instituto de Estudios Gienenses, el artículo "La colección de antigüedades arqueológicas del Padre Fr. Alejandro Recio". En el apartado « $\mathrm{C}$ » dedicado a las Antigüedades romanas y paleocristianas destaca, entre otros objetos un capitel de pilastra, fechado en los siglos II-III d.C., labrado en piedra arenisca fosilifera, elemento arquitectónico que había sido reutilizado como tapa de un sepulcro cristiano. Dicho sepulcro, al parecer, estaba formado con "ladrillos» que presentaban un crismón y el epígrafe «Chioni» repetido por triplicado en tres de sus costados (dicho epígrafe aparecía dos veces al revés y una al derecho). El enterramiento fue encontrado de forma casual en la finca de los señores de Elosúa, conocido como Torre del Corral (Martos) (Recio, A. y Fernández Chicarro, C. 1959, p. 153 y 158 , fig. 11).

En 1960 se publicaron los números 8-11 de Hispania Antiqua Epigraphica. En relación a Martos cita la inscripción $n .^{\circ} 1800$ : «Finca Torre del Corral. Sepulcro cristiano de ladrillos con la inscripción repetida por triplicado en tres de los costados: Chioni» (1957-1960. p. 42).

En 1961 P. Palol edita en Scritti d' Istoria dell Arte in onore Mario Salmi «Placas en cerámica decoradas paleocristianas y visigodas». Expone una serie de conclusiones interesantes:

1. Forman parte de un notable conjunto ornamental.

2. Se trata de un elemento de origen Africano, ya que han aparecido piezas procedentes de un taller del Norte de África (Cartago o Lamniana).

3. Piezas similares a las encontradas en Hispania se han documentado en Francia y en Bélgica.

4. Se utilizó como elemento ornamental sobre todo en la Bética desde los comienzos del cristianismo hasta el final de la época visigoda. Tanto en la Bética como en la Lusitania se observa una tendencia al empleo de las aplicaciones de ladrillos ornamentales, empleo que se desarrolla al mismo tiempo que la escultura monumental en mármol o piedra.

5. Es difícil establecer una secuencia cronológica. Por tanto no se puede establecer un cuadro evolutivo seguro debido a la falta de excavaciones sistemáticas con hallazgos de ladrillos in situ y a la falta de textos literarios que hagan referencia a ellos. La única manera de clasificación cronológica es acudir a comparaciones estilísticas. 
6. Existe una gran amplitud temática. Clasificó estas placas atendiendo a su decoración, al igual que lo hiciera Fariña Couto en 1940. Añadió nuevos motivos decorativos y otros ejemplares :

Temas geométricos:1a.- Plafones: Son Peretó (Manacor, Menorca); Casa de Maera (Era de las Llanas, Guillena, Sevilla); Villaricos y Herrerias (Almería). Paradero desconocido. Posiblemente conservado en el Museo Arqueológico Nacional.1b.- Círculos cruzados y estrellas o flores: Museo de Córdoba (varios ejemplares); Museo de Cervera; Cortijo Los Libros (Córdoba); Museo Arqueológico de Sevilla, Museo de Granada (procedente de Almuñecar; Museo Arqueológico Nacional. 1c.- Círculos y estrella o flores con crismón: Espejo (Córdoba). Colección Caballero Infantes. Depositado Museo Arqueológico Nacional; pieza depositada en el Museo de Madrid, citada por Rada y Delgado, pieza recogida por Fariña y ejemplar del Museo de Sevilla. Temas de Peltas: Subdivide el grupo en dos: Peltas sin símbolos cristianos y Peltas con símbolos cristianos. Temas animales. Temas vegetales. Crismones. Establece tres subgrupos: 1a.- Temas sencillos; 1b.- Crismones bajo arco. Grupo Marciano y Bracario; 1c.- Otras piezas con letrero. Tema de Cráteras y Temas figurados (1961, pp. 131-153).

En 1962 presenta al Congreso di Studi sull Arte dell Alto Medioevo Stucchi e mosaici Alto Medievali «A propósito de las placas de cerámica decoradas hispanorromanas». En este caso se trata de una síntesis del texto entregado en el Homenaje a Mario Salmi aunque en esta ocasión se añaden algunos ejemplares depositados en el Museo Arqueológico de Sevilla. Considera a estos objetos como elementos de ornamentación de edificios, descarta que se trataran de placas de función funeraria fijadas en los sarcófagos de madera a través de grandes clavos. Señala, una vez más, la dificultad de realizar un corpus completo ya que en la mayoría de los casos se trata de hallazgos casuales. El área de expansión de estos elementos cerámicos se limita a la Bética y a la Lusitania (en ésta última región hallados en menor número), regiones en las que según palabras del propio Palol «el arte del mármol se desarrolló de una forma pobre y popular», empleándose «placas cerámicas que por facilidad de la técnica permitieron mayor variedad de temas y más fantasía creadora, incluso, que entre las piezas de buena escultura» (1962,300-302).

A. Cabezón en el año 1964 publica el artículo titulado «Epigrafía Tuccitana», en la revista Archivo Español de Arqueología, entre los epígrafes que recoge cita dos ladrillos cristianos, que ya habían sido dados a conocer por Hübner y por Recio y Fernández Chicarro. El hallazgo se rea- 
lizó en 1955 en la finca conocida como "Torre del Corral" (Martos, Jaén). Formaban parte de un sepulcro cristiano y hoy se conservan en la colección arqueológica del Colegio de San Antonio. Cabezón los describe en los siguientes términos: "Su forma es de ortoedro, uno de ellos tiene una rotura en la parte derecha inferior, de $9 \mathrm{~cm}$. de ancho por 16 de alta, lo que hace que tenga la forma trapezoidal. Miden $30 \mathrm{~cm}$. de ancho por 18 de alto y 6 de grosor. El epígrafe se halla en tres costados: superior, izquierdo e inferior y las letras están en relieve. El crismón figura en los dos ladrillos pero al revés. En el costado izquierdo está en sentido inverso al de los otros dos. Las letras ocupan toda la medida del grosor, $6 \mathrm{~cm}$. excepto la "C» y la «O" que tienen $45 \mathrm{~mm}$. Como es natural el epígrafe del costado izquierdo es más pequeño que el de los otros costados y es como sigue: «(Crismón invertido) CIIONI/ INOIIIC. De Chion, en genitivo». Cree que se trataría de la marca de los ladrillos o del propietario de la fábrica en que se realizaron. Los considera ladrillos cristianos y los fecha entre el siglo IV y el $v$ d.C. Señala como paralelo, con el crismón invertido una «tegula» encontrada en Osuna pero con el término "vivas» (Cabezón, A. 1964, p. 119).

Manuel Gómez Moreno en 1966 dio a conocer "Primicias del arte cristiano Español» en Archivo Español de Arte. Dedica un pequeño apartado a los ladrillos. Considera que tienen un carácter funerario. Recoge algunos ejemplares decorados con crismón en lugar preferente enmarcado con diversus letreros: «Bracari vivas cum tuis», "Marciana vivas in (Christo)», "Spes in Deo», "Salvo epicospe Marciane»; "Salvo Ausintio», "Camilla in Deo decedit e vita», «Felix Asella», «Lupicus vivit», «Elia Elina cun filis gaudet subule salva». Señala que el ejemplar dedicado a Bracarius se descubrió en Alcalá del Rio (Sevilla), no se trataba de un único ejemplar si no de más de un centenar de ejemplares apilados. Con respecto al de Marcianus especifica que en Bujalance (Córdoba) había un edificio construído con este tipo de iadrillos. Identifica a Bracarius con un obispo que ocupó la silla episcopal de Mérida en el año 381 y a Marciano con un obispo de la diocesis de Hispalis hacia el año 420 (1966, p. 111).

En 1967 P. Palol publica la monografía Arqueología Cristiana de la España Romana, incluye un apartado titulado «La decoración escultórica en cerámica de época paleocristiana y visigoda". Se trata del mismo texto que publicó en el año 1961. Presenta un inventario amplio y describe un conjunto de placas o ladrillos decorados con diversos temas. Señala como la falta de restos arquitectónicos en la Bética cristiana está compensada por la riqueza y abundancia de elementos decorativos y de inscripciones 
tanto funerarias como las referentes a consagraciones de templos (1967, 255-272).

En el año 1968, este mismo autor, edita la obra Arte Hispánico de la época visigoda. Dedica un apartado a los ladrillos con ornamentación plástica en molde característicos del valle del Betis. Considera que: tienen un origen Africano, ocupan un espacio de tiempo muy amplio, su producción arranca del siglo IV y se prolonga hasta la primera década del siglo vili; en relación a su temática señala que hay elementos que tienen sus raíces en el arte romano, temas claramente paleocristianos (cráteras y crismones) y otros de talla a bisel (entrelazados, estrellas geometrizadas, etc), comparables a la ornamentación hispanovisigoda sobre mármol (1968, p. 82).

En el mismo año en su estudio «Herencia romana en el arte ornamental de tiempos visigodos» presentado en Los Coloquios celebrados en conmemoración de los XXV años de la fundación del Consejo Superior de Investigaciones Científicas. España en la crisis del arte europeo, considera que los ejemplares debieron servir para recubrir los muros de los edificios. Con respecto a la decoración vuelve a observar que los ejemplares más antiguos presentan motivos derivados de lo romano y de lo Africano y los más modernos permiten seguir la misma temática de la escultura ornamental hispanovisigoda de mármol (1968, 56-57)

En 1973 E. Serrano Ramos publica «Materiales de Manguarra y San José (Cártama) en la revista Jábega. En el artículo se recogen las piezas más interesantes aparecidas antes de los trabajos de excavación llevados acabo en 1972 en la finca denominada Manguarra y San José (Málaga). Junto a monedas romanas de época Bajo-Imperial, fragmentos de Terra Sigillata Clara A, C, D lisa y D estampada; cerámica común y piezas de metal menciona la presencia de ladrillos con decoración estampada: "Ladrillo tardorromano de $33 \times 25 \times 5 \mathrm{~cm}$. Semillón central en forma de roseta enmarcado con un rombo con decoración de clavos de cuyos vértices surgen cuatro pétalos mayores y entre estos unos capullos comprendidos por una pareja de finas hojas, cerrado todo él por un piso de clavos". El segundo tipo de ladrillo aparecido presenta la misma decoración que el anterior, cambia el motivo decorativo central: "Círculo de hojas que enmarcan una roseta de ocho pétalos» (1973, pp. 67-70).

En 1976 la autora citada anteriormente y A. Luque Moraño dan a conocer en el Noticiario Arqueológico Hispánico «Memoria de las excavaciones de Manguarra y San José (Cártama, Málaga). Se dan a conocer los resultados obtenidos durante la primera campaña de excavaciones en la 
finca Manguarra y San José, Dehesa Alta, propiedad de la familia Tembour y de la Muela. A continuación citamos las placas decoradas documentadas: Cuadrícula A-2. "Ladrillo estampado con motivo de roseta (Lám. XIV.2) y ladrillo estampado con motivo cruciforme (Lám. XIV.1)" (1976, p. 495); Cuadrícula A-3. «Ladrillo estampado con motivo crucifrme al igual que el de la lámina XIV.1 y ladrillo estampado con motivo de roseta igual que el de la lámina XIV.2» (1976, p. 497); Recinto I.- «Ladrillo estampado con motivo cruciforme. Igual al de la lámina XIV.1» (1976, p. 501); Recinto L-A.- «Medio ladrillo con motivo cruciforme igual que el de la lámina XIV.1» (1976, p. 505 y 511); Recinto IV.- «Un trozo de ladrillo estampado con motivo de roseta igual que el de la lámina XIV.2» (1976, p. 514).

En 1978 H. Schlunk y Th. Hauschild publican la obra monográfica Die Denkmäler des frühchistlichen und wesgotischen Zeit. En el apartado dedicado a los monumentos del siglo vi y comienzos del siglo vII abordan el tema de los ladrillos estampados. Realizan las siguientes apreciaciones:

1. Proceden de la Bética (especialmente de las provincias de Sevilla, Córdoba, Granada, Málaga y Cádiz).

2. Aparecen en territorios pequeños y limitados, donde ha de buscarse también el respectivo taller.

3. Ladrillos semejantes se conocen sobre todo en el África romana, especialmente en Túnez y en la parte oriental de Argelia. Entre los talleres Africanos e hispanos pudieron existir relaciones muy estrechas ya que algunos ladrillos españoles repiten casi literalmente los mismos motivos que los africanos.

4. Su fabricación comenzó en época romana.

5. Entre las representaciones iconográficas destacan temas ornamentales geométricos, por lo general dentro de un círculo, diferentes composiciones de peltas; temas cristianos (pájaros, delfines, cráteras, crismones, etc.); faltan por el momento representaciones bíblicas o de santos tan frecuentes en Túnez a excepción de las escenas representadas en el ladrillo procedente de Lebrija (Sevilla).

6. Cree que las placas estarían destinadas a ser empotradas, en fila, dentro de paredes tal y como demuestra un ejemplar de Sevilla que encontraría su complemento en el ladrillo siguiente. Otros ejemplares que presentan una ranura en ambos lados cortos, parecen haber servido de 
decoración de techos, cubriendo vigas paralelas. Techos construídos con la ayuda de ladrillos, en este caso pintados, pueden documentarse en la primera mitad del siglo III en Doura-Europos y más tarde en Egipto y Túnez.

7. Las formas y las dimensiones son muy variadas, se documentan ladrillos pequeños de $32-22 \mathrm{~cm}$. y placas grandes de $60-40 \mathrm{~cm}$.

Citan algunos ejemplares:

1. Pieza procedente de Osuna (Sevilla) con representación de palmera con un caballo atado a cada lado. Composición que se conoce en mosaicos pavimentales de Túnez como el procedente de Hadrumentum (Sousse) y conservado en el Museo Arqueológico de Sousse, $n .^{\circ}$ inventario: 52120 . Los autores creen que esta pieza pudo haber formado parte de la decoración parietal de una casa.

2. Varios ejemplares con la inscripción «Bracari vivas cum tuis», procedentes de la Bética (tal vez Ronda) conservados en el Museo Arqueológico Nacional de Madrid. Esta serie alcanzó gran difusión. Schlunk y Hauschild se ven sorprendidos porque composiciones semejantes se realizan en las cubiertas de libros bizantinos fechados en la segunda mitad del siglo vI con ligeras variaciones tal y como se puede comprobar en una tapadera de plata realizada para un libro procedente del monasterio de San Cion, cerca de Myra (Asia Menor) fechado entre el 567-575 d. C. y conservado en Washington en la Dumbarton Oaks Collection.

3. Ladrillo completo y fragmento de otro decorados con candelabro de siete brazos bajo arco, árbol e inscripción griega «Mixal», correspondiente al nombre hebreo «Michal». Proceden del Cortijo de la Vizcondesa, cerca de Ronda, lugar en el que se encontraron numerosos ladrillos con la inscripción de «Bracari».

4. Ejemplar incompleto procedente de Lebrija (Sevilla) conservado en una colección particular en el que se observa en el ángulo inferior derecho un hombre colgado de un palo. Este presenta tiras de paja colgando de la cabeza y de las manos. Se le acerca un soldado que lleva en la mano un recipiente con fuego. Falta la escena del lado inferior izquierdo donde tal vez se desarrollaría otra escena de martirio. En la parte superior de la pieza se ha representado la escena de Daniel en el foso de los leones, el primero de los mártires como lo llamó Cipriano. 
En ese mismo año J.M ${ }^{a}$ Blázquez presenta en las Actas del I Congreso de Historia de Andalucía. Fuentes y Metodologia. Andalucía en la Antigüedad «La Bética en el Bajo Imperio». En el apartado dedicado al cristianismo dedica un epígrafe a las placas decoradas. Expone, como ya hiciera en otros estudios: su origen, clasificación y algunos ejemplos (Blázquez, 1978, pp. 268-270).

En 1980 E. Serrano Ramos y A. Luque Moraño dan a conocer en el Noticiario Arqueológico Hispánico "Memoria de la segunda campaña de excavaciones en la villa romana de Manguarra y San José, Cártama, Málaga". Citan los siguientes ejemplares de placas decoradas: Recinto B2.- "Cuatro trozos de ladrillos estampados con motivo circular y dos cruciformes. . $^{\circ}$ de Inv. B2, 6/1; 6/2; 6/3 y 6/16» (1980, p. 271); Recinto B3."Un trozo de ladrillo estampado con motivo circular. N. ${ }^{\circ}$ de Inv. B3.5" (1980, p. 272 y 289); Cuadrícula B5.- «Un fragmento de ladrillo estampado. N. ${ }^{\circ}$ de Inv. B5.2» (1980, p. 306); Cuadrícula B4.- «Dos fragmentos de ladrillos estampados. N. ${ }^{\circ}$ de Inv. B.4 2 y 3 " (1980, p. 312 y 313); Recinto T.- «Un trozo de ladrillo estampado con motivo cruciforme. $\mathrm{N} .^{\circ}$ de Inv. T7» (1980, p. 319 y 321 ); Recinto Y.- «Un trozo de ladrillo estampado con motivo cruciforme. $\mathrm{N}^{\circ}$ de Inv Y.1» (1980, p. 326 y 331); Cuadrícula C.- «Un trozo de ladrillo estampado con motivo cruciforme. N. ${ }^{\circ}$ de Inv. C7» (1980, pp. 335 y 321$)$.

En 1981 E. Serrano Ramos y R. Atencia Pérez publican la monografía Inscripciones latinas del Museo de Málaga. Para Ronda citan: «Ladrillo rectangular de $0,30 \mathrm{~cm}$. de alto por $0,20 \mathrm{~cm}$. de ancho por 0,05 de grueso con decoración en relieve. Dos columnas sostienen un arco con parte de una venera y en el espacio central el anagrama de Cristo con el Alfa y el Omega a cada lado. Sobre los capiteles de las columnas aparecen flores liliformes de tres pétalos y enmarcándolo todo el siguiente letrero de izquierda a derecha «Bracari vi/vas cum tuis». Nuestra pieza procede de Ronda de donde pasó al Museo Loringiano y luego al de Málaga. El número de éstos ladrillos es muy elevado y citan los ejemplares aparecidos en Mérida; Morón de la Frontera (Sevilla); Hispalis (Sevilla); llipa (Los Llanos, Sevilla); Astigi (Ecija, Sevilla); Asta Regia (Jérez, Cádiz), ejemplares de procedencia desconocida en el Museo Arqueológico Nacional, en la Academia de la Historia de Madrid, en la antigua colección Natan Weterell de Sevilla y en la colección Bonsor de Mairena, entre otros» $(1981$, p. 48)

En ese mismo año A. Marcos Pous publica en la revista Corduba el artículo «Letreros de ladrillos cordobeses con la fórmula cristiana antigua 
Salvo Ausentio". Se trata de fragmentos de ladrillos que presentan en sus cantos o bordes verticales restos de letreros de contenido cristiano, con letras capitales en relieve; conservados en los Museos Arqueológico Nacional y de Córdoba. Cree que proceden de las excavaciones practicadas en 1865 por la Comisión del Cuerpo del Estado Mayor, en algún lugar del término municipal de Espejo (Córdoba) o de Ategua. El taller podría estar en ese territorio o en otro próximo, ya que el mercado de materiales de este tipo sería local o comarcal en una época de mercados activos en radios no muy extensos. Las piezas no presentan restos de mortero de cal por lo que cree que el yacimiento donde se encontraron pudo ser un almacén, un taller alfarero o en un edificio en construcción. Su lectura no la considera fácil. El texto siempre empieza por «SALVO AUSENTIO» y sigue con expresiones diversas: 1.- VIVAS FORTUNIO; 2.- ? ? .../... IN ALFA CRISMON y OMEGA»; 3.- ....(viva)S in Chrito; 4.- SENTIO ALFA CRISMON OMEGA. Fecha los ejemplares recopilados desde finales del siglo IV comienzos del siglo $\mathrm{V}$ a finales del siglo VI comienzos del siglo VII (1981, pp. 49-68).

En 1982 C. Martín Gómez publica en la revista Museos «Placas decoradas de época paleocristiana y visigoda, con inscripción del Museo Arqueológico de Sevilla». En él dio a conocer una interesante colección de ladrillos o placas de cerámica decorada que se conservan en el Museo Arqueológico Provincial de Sevilla. Distinguió tres grupos: a) placas o ladrillos con crismón y otros motivos decorativos; b) placas o ladrillos con crismón, inscripciones y otros motivos decorativos; c) placas o ladrillos con inscripción. Considera que el origen de estos elementos hay que buscarlo en el Norte de África y desde allí pasarían a la Bética y a otros lugares de la Península y Baleares. Para la zona de la Bética distingue varios talleres, entre los que destaca los de Ronda y Morón. Con respecto a su funcionalidad considera varias posibilidades: ornamentación de paredes y techumbres de edificios; cubrición de las paredes de las tumbas y cobertura de sepulturas (1982, p. 37).

M. A. Alonso Sánchez en ese mismo año publica en la /l Reunió d'Arqueologia Paleocristiana Hispánica (Montserrat) «Crismones con Omega-Alfa en España". En el artículo se recogen los testimonios paleocristianos, visigodos mozárabes y románicos que presentan como motivo decorativo el crismón acompañado de omega-alfa. Dentro del grupo de testimonios paleocristianos y visigodos hace mención de catorce ladrillos distribuidos en los siguientes museos: "tres en el Museo Arqueológico de Córdoba; tres en el Museo de Santa Cruz de Toledo; dos en el Museo 
Arqueológico de Huelva; dos en Valencia (uno en el Museo de Bellas Artes y otro en el Museo Nacional de Cerámica «González Martí»); uno en el Museo Arqueológico de Sevilla; uno en el Museo Arqueológico de Granada, uno en el Museo de Arte Sacro de la colegiata de Osuna, uno en el Museo Arqueológico de Valladolid». Considera que todos los ejemplares tuvieron un carácter funerario (1982, p. 229).

En 1983 R. Ramírez de Arellano en su obra Inventario Catálogo Histórico-Artístico de Córdoba. En el apartado dedicado a Córdoba capital y más concretamente en el destinado a la Arqueología Latino-Bizantina o Hispano-visigoda, menciona los siguientes ejemplares de ladrillos con decoración a molde «tres ladrillos prensados a molde con labores, en el Museo dos proceden de Almodovar. Tres ladrillos hallados en La Corredera de Córdoba y en Puente Genil» (1983, p. 21).

En 1987 A. Gómez Gómez en el Anuario Arqueológico de Andalucía da a conocer los trabajos de prospección realizados en el entorno de Córdoba «Prospección arqueológica superficial en los términos municipales de Baena, Castro del Rio, Espejo y Córdoba", entre los hallazgos realizados en el último trimestre de 1986 cita unos ladrillos con inscripciones en los bordes en los que se exalta a un tal "Amazonius", proceden de Vieco (1987, p. 114).

En el mismo año R. Puertas da a conocer en la revista Mainake "Los hallazgos arqueológicos de Torreblanca del Sol (Fuengirola). En el conjunto arqueológico formado por termas romanas, una factoría y una necrópolis se documentaron los siguientes ejemplos de placas decoradas: Cuadro A-4 (fig. VII-VIII).- «Placa de cerámica con decoración de temas vegetales. Arcilla marrón clara con abundantes desengrasantes de tipo basto. Grosor medio $45 \mathrm{~mm}$.» Cuadro A-5 (fig. VIII-IX).- «Placa de cerámica con decoración de temas vegetales. Arcilla marrón oscura con abundante desengrasante de tipo basto. Grosor medio 40 mm." (1986-1987, p: 160)

Ese mismo año P. Palol en el XXXIV Corso di Cultura sull' arte Ravennate e Bizantina. Seminario Internazionale di Studi su Archeologia e Arte nella apagna tardorromana, visigotica e mozarabica publicó «La escultura paleocristiana en Hispania». Se incluye un apartado titulado Escultura ornamental para la arquitectura y en él se cita el grupo de ladrillos con decoración en relieve y fabricación a molde localizados en el valle del Guadalquivir, en la Bética romana. Considera que estos elementos ornamentales llenan un amplio espacio de tiempo desde el siglo IV hasta fi- 
nales del siglo VII o principios del VIII. Especifica, una vez más que hay ejemplos con temática tardorromana vinculada a temas frecuentes en la decoración musivaria de las villae de los grandes «fundi» Bajo-Imperiales; piezas con temas claramente paleocristianos; para terminar la serie con piezas de estilización geométrica de clara inspiración tardorromana y adaptación genuina de la escultura de tiempos visigóticos en especial de los centros urbanos cordobés, emeritense y toledano (1987, pp. 302-303).

De la misma fecha es el estudio de P. Rodríguez Oliva titulado «Spes in Deo. A propósito de una marca impresa sobre un fragmento cerámico hallado en la necrópolis romana del Faro de Tordox (Málaga)", publicado en la revista Mainake. Presenta el hallazgo de un fragmento cerámico, tal vez de un «dolium» con la inscripción «Spes in Deo». Está realizada en un doble estampillado y enmarcada dentro de lo que parecen las siluetas de las suelas de una pareja de sandalias o zapatos puntiagudos. Se encontró sobre una cubrición de tumba tipo «mensae» cubierto con «opus signinum». Cita algunos objetos con inscripción semejante y entre éstos menciona «una serie de tégulae encontradas en el Olivar de Pero Alonso de Castro cerca de la Fuen Blanquilla, Bujalance, Córdoba" (Rodrígez Oliva, P. 1986-1987, pp. 215-224 y 1988, pp. 181-183).

En 1988 Palol y G. Ripoll en la Monografía Los godos en el occidente europeo, dedican un apartado a la ornamentación escultórica en la arquitectura visigoda; abordan el tema de los ladrillos, elementos típicos, como ya se ha indicado en varias ocasiones de la bética occidental y localizados concretamente en el valle del Guadalquivir. Se exponen algunas de las conclusiones ya referidas en otros estudios: gran variedad de motivos enlazándose los temas profanos tardorromanos (cacerías o jinetes) con los paleocristianos (crismones, vasos eucarísticos o inscripciones cristianas) y los esquemas a bisel de época visigoda; el origen de las piezas hay que buscarlos en la región de Cartago y perduran con otro espíritu en tiempos musulmanes, como una característica de esta región (1988, 205-207).

En ese mismo año X. Barral i Altet, dio a conocer en la III Reunió d'Arqueologia cristiana Hispánica «L'escultura arquitectonica i decorativa en els monuments religiosos de l'Antiguitat tardana Hispana». El autor considera que no solo los edificios religiosos sino también los civiles presentaron una decoración monumental asociada a los ladrillos de cerámica estampada hechos a molde. Según el autor este tipo de decoración se encontraba en tres lugares concretos de los edificios: pavimentos (constatado en los hallazgos de Burguillos), paramentos y techumbres (tanto 
en el exterior, como en el interior del edificio). Sitúa el área de dispersión de estas piezas en la zona meridional de la península y las otorga un amplio espacio cronológico que arrancaría desde el siglo IV $(1994,42)$.

C. González Román y J. Mangas Manjarrés publican en el año 1991 el Corpus de Inscripciones latinas de Andalucia. Volumen III. Jaén. Tomo II. Recogen los ladrillos hallados en la finca Torre del Corral (Martos) que ya habían sido publicados por A. Recio y Fernández Chicarro en 1959 y por A. Cabezón en 1964. Con respecto a ellos hacen ei siguiente comentario: "Dos ladrillos de los que uno se conserva completo y el otro presenta una fractura en la parte derecha inferior. La inscripción se encuentra por triplicado en tres lados y está precedida por un crismón. Medidas $18 \times 30 \times 6$; altura de las letras 6-4,5. Texto «CHIONI». Letras capitales cuadradas, de trazo regular y buena incisión. Puede proceder de los siglos IV-V d.C. (Gónzalez Román, C. Y Mangas manjerrés, J. 1991).

En el año $1992 M^{a}$.L. Loza Azuaga publica en la revista Mainake «Tipología y catálogo de las placas cerámicas decoradas a molde de época tardorromana y visigoda conservadas en el Museo de Málaga». Señala como «su utilidad, origen y cronología plantean numerosos interrogantes derivados de la abundancia y diversidad del material, ya que rara vez proceden de excavaciones sisteméticas que permitan encuadrarlas en un marco histórico concreto". Estas piezas han sido siempre designadas como «ladrillos decorados», la autora se inclina por utilizar el término de «placas decoradas". Tradicionalmente se han considerado como un elemento decorativo que tiene su origen en el Norte de África (Túnez) pero Loza Azuaga cita ejemplares fechados en el siglo III y hallados en diversas villas de la provincia de Málaga: Manguarra y San José (Cártama) y del Secretario (Fuengirola) que no permiten hablar de influencia norteafricana, en todo caso plantea la hipótesis de un desarrollo paralelo en ambas regiones. Aborda de forma somera los pasos de fabricación de éstas placas. Cree que su función fue la de formar parte de la decoración arquitectónica de los edificios (paredes, techos y suelos). Dio a conocer una serie de placas decoradas que forman parte del Museo Arqueológico Provincial de Málaga y que en su mayor parte proceden de yacimientos de esta provincia: villas de Manguarra y San José (Cártama), El Secretario (Fuengirola) y las donadas por Peregrin Pardo. En este mismo lote se encontraban una serie de placas procedentes de una villa al norte de Osuna (Sevilla); otras de las termas romanas de Torre Blanca (Fuengirola). A estos ejemplares hay que añadir las piezas de la antigua colección Loring. Establece cinco grupos en función de la decoración, sin tener en cuenta las diferencias cronológicas: 1.- Placas 
decoradas con tema vegetal; 2.- Placas decoradas con motivos geométricos; 3.- Placas decoradas con temas de peltas y 4.- Placas decoradas con crismones (Loza Azuaga, Mํ‥L. 1991-1992, pp. 252-265).

En 1993 R. Barroso Cabrera y J. Morín de Pablos publican la monografía El árbol de la vida. Un estudio de iconografía visigoda: San Pedro de la Nave y Quintanilla de las Viñas. En este trabajo realizan un estudio de aquellas piezas visigodas que presentan como elemento iconográfico el llamado "árbol de la vida». Dan una especial atención a los relieves ornamentales de las iglesias de San Pedro de la Nave y Quintanilla de las Viñas. En relación a este símbolo mencionan los ladrillos paleocristianos de la serie «Mixal» (Cortijo de la Vizcondesa, Ronda, Málaga). Estos ejemplares presentan composiciones semejantes a las documentadas en las series de Bracario y Marciano, todos ellos caracterizados por presentar un motivo central enmarcado por dos columnas y cobijado bajo venera. En la serie «Mixal» el elemento central es un candelabro de siete brazos y Mixal es el nombre del Arcángel San Miguel, santo protector del pueblo hebreo (Dan. X.21; XII.1-2 y Zac. II.8), pero también lo es del pueblo de Dios (Apoc. XII.7). Los autores consideran que la iconografía tendría un claro significado cristiano y un profundo contenido Apocalíptico: «Las siete lámparas que lucen delante del trono divino (los dones que derrama el Espíritu Santo sobre su Iglesia) y Dios como origen y fin último de todas las cosas (Apoc. IV.5; V.6; I.8 y XXII.13)» (1993, pp. 25-27, fig. 12).

En 1994 los autores antes citados dan a conocer en la revista Zephyrus «El nicho-placa de Salamanca del MAN y otros testimonios arqueológicos del culto a San Miguel en época visigoda". Se estudian una serie de testimonios que prueban la importancia que adquiere el culto de éste arcangel, en la peninsula ibérica, desde época visigoda. Entre éstos testimonios citan: el nicho procedente de Salamanca; los ladrillos de la serie «Mixal», una pizarra de Carrio (Asturias) y la inscripción de una fíbula de charnela procedente de la necrópolis de Alcalá de Henares. Todas las piezas ayudan a comprender la fuerte vinculación de la cultura alto-medieval hispana con la que se desarrolló en tiempos del reino visigodo de Toledo. Con respecto a los ladrillos con decoración estampada de la serie "Mixal» señalan que la aparición del candelabro no sirve como testimonio de la existencia de un culto judio ya que este elemento no es extraño al arte visigodo; entre otros ejemplos citan el que aparece figurado en el porche del brazo norte del crucero de San Pedro de la Nave (Zamora), junto a un racimo de vid. Creen que podría representar el pasaje del Apocalipsis de San Juan (I, 12-13; IV.5; EX XXVI.34 y ss.). El árbol que aparece figurado en el ángulo superior de- 
recho lo interpretan como símbolo de la divinidad parangonable al crismón y como tal su aparición en el arte paleocristiano y visigodo es omnipresente. Consideran que la inscripción alusiva a San Miguel no es extraña teniendo en cuenta que la decoración del ladrillo debe interpretarse como una imagen simbólica del templo, es decir del propio Cristo. Opinan que la forma griega del nombre podría indicar que su culto procediera de Oriente y que este llegara a la península a través de la costa africana (1994, pp. 284-287).

J. Serrano Carrillo publica en 1995 Guía del Museo Histórico Municipal de Cañete de las Torres (Córdoba) y concretamente en el apartado dedicado al mundo hispanovisigodo recoge dos ejemplares expuestos en esta institución: uno de los ejemplares procede del Cortijo de Vieco (Cañete de las Torres); presenta una inscripción a molde en el canto donde, según este investigador y suguiendo al profesor Stylow, se puede leer "Ama(zoni) vivas". J. Serrano cree que pueda tratarse de un obispo de Córdoba o Ecija que vivió durante el siglo VII. Con respecto a su funcionalidad piensa que estaría relacionado con la construcción de edificios religiosos y con las cubiertas a dos aguas de ciertas tumbas de la época. El segundo ejemplar presenta motivos decorativos geométricos en relieve, círculos, estrellas y flores simétricas; en este caso engloba el ejemplar dentro del grupo de «placas de terracota» que se emplearían en los edificios cristianos a partir del siglo vi (1995, p. 69 y fig. 117).

En el Corpus Inscriptionorum Latinorum. Conventus Cordubensis (CIL II 2/7) editado por U. Stylow; C. González Román y Géza Alföldy en el año 1995 se recogen los siguientes ejemplares de ladrillos:

1. Hallado en Bujalance, entre las ruinas de la Ermita de San Benito. Enviado a la Real Academia de la Historia de Madrid. Presenta inscripción [A] MAZONI VIVAS.

2. Encontrado en el Cortijo de Vieco a $5,5 \mathrm{~km}$. de distancia de Cañete de las Torres y a medio camino de la carretera que conduce a Baena. Fragmento: $5,5 \times 19 \times 17 \mathrm{~cm}$. Se conserva en el Museo Histórico de Cañete. Inscripción AMA[zoni] VIVAS.

3. Procede de la finca El Hornillo (Cañete de las Torres). Se conserva en Bujalance en casa del poeta Mario López, allí fue descrito y fotografiado. Completo. Inscripción AMAZONI VIVAS.

4. Dos ejemplares descubiertos en el Cortijo de Lorilla a $5 \mathrm{~km}$. de la ciudad de Bujalance en la carretera que conduce a Castro del Río. Conservado en el Museo Histórico de Cañete, allí fue descrito fotografiado 
en 1983. Se conserva un ejemplar completo y otro fragmentado: $5,5 \times 19 \times$ 16. Inscripción [Ama] ZON (i) (1995, p. 53. 7,194 a, b, c, y d).

5. Ejemplar procedente del Olivar propiedad de Pedro Alonso de Castro, situado cerca de Fuenteblanquilla, junto a la villa de Bujalance. Se hace mención a las circunstancias del hallazgo «... arrancando un par de aceitunas se descubrió un edificio antiguo con más de mil y quinientas piezas de barro cocido, como ladrillos de tamaño de media vara de largo y de grueso tres dedos, todas con estas dos diferentes letras». Depositados en el Museo Arqueológico Provincial de Córdoba ( $\mathrm{n} .^{\circ}$ inventatario 1284112852). Inscripción: MARCIANA «Chrismon» VIVAS IN (Christo) (1995, 7,195a) y SPES IN DEO «Chrismon» [Dos flores] $(1995,7,195 b)$.

6. Ejemplar hallado en Córdoba, en las laderas Bajas de San Jerónimo, junto a la pista de aterrizaje de avionetas que se encuentra enclavada en la carretera que lleva desde Medinat-Al-Zahra a Almodovar, junto al arroyo de las Huertas a $5,5 \mathrm{~km}$. de la ciudad de Córdoba. Inscripción VIVAS IN DEO $(1995,7,727 a)$.

\section{CATÁLOGO}

En este estudio presentamos setenta y nueve nuevos ladrillos, algunos de ellos, como ya dijimos en la introducción, presentan nuevas composiciones que no habían sido constatadas en los numerosos estudios que se han realizado sobre éstas piezas. Nuestros ejemplares proceden de Sevilla: Herriza del Ciervo (1), Pedro Cruzado (2), El Rubio (2), Viso del Alcor (6), Morón de la Frontera (4) y Cortijo de El Coronel (2); Córdoba: Cortijo La Estrella, Posadas (7) y Huelva. Torreón de Gerena (50). También se dan a conocer tres piezas de la Depuradora Campanario; una de procedencia desconocida y otra de la Colección Fajardo de Osuna (Sevilla) y cedida a la Colección Alhonoz. Todos estos ejemplares se suman a los documentados, por un gran número de autores, en otras localidades de éstas y otras provincias andaluzas: Sevilla: Lebrija, Osuna, Alcalá del Rio y Cortijo de Barbuan; Córdoba: Córdoba ciudad (laderas Bajas de San Jerónimo), Aldea del Hoyo (Bélmez), Cortijo de los Libros, Villaviciosa de Córdoba, Espejo, Ategua (?), Cañete de las Torres (Cortijo de Vieco y Finca el Hornillo) y Bujalance (Ermita de San Benito, Cortijo de Lorilla, Olivar de Pedro Alonso de Castro en Fuenteblanquilla); Málaga: Ronda (Cortijo de la Vizcondesa). Fuera de ámbito de la Bética se han documentado ejemplares aislados en las provincias de Badajoz (Burguillos), Valencia y Mallorca. 
Ladrillo n. ${ }^{\circ}$ 1. (Fig. 1a. Lám. 1a.).- Procede de Herriza del Ciervo (Sevilla) (plano 1). El hallazgo se realizó cerca del Cortijo El Ciervo y a 100 $\mathrm{m}$. del punto kilométrico de la carretera a Ecija: C3510-49 . La pieza está completa tan solo se encuentra fragmentada en la esquina. Sus dimensiones son: Longitud: $28,5 \mathrm{~cm}$; Ancho: $26 \mathrm{~cm}$; y Grosor: $2,5 \mathrm{~cm}$. En el anverso presenta como motivo central un cuadrado de lados cóncavos en alto relieve del que parten ocho líneas. Las que coinciden con los ángulos rematan en hojas lanceoladas formando un florón en cruz. Toda la decoración está enmarcada por un listel que corre a $3,5 \mathrm{~cm}$. del borde. Es la única pieza que en el reverso presenta las huellas de los dedos formando una cruz.

Ladrillo n. ${ }^{\circ}$ 2. (Fig. 1b. Lám. 1b).- Procede de Pedro Cruzado (Sevilla). Próximo a la carretera de Marinaleda a Estepa. A $1 \mathrm{~km}$. del Cortijo de Pedro Cruzado. Fragmento. Esquina. Dimensiones: Longitud: $19 \mathrm{~cm}$.; Ancho: $25 \mathrm{~cm}$., y Grosor; $4 \mathrm{~cm}$. La decoración vegetal formada por tallos con zarcillos opuestos desplazados y flores espigadas está rodeada por un listel que corre a $3,5 \mathrm{~cm}$. del borde.

Ladrillo n. ${ }^{\circ}$ 3. (Fig. 1c. Lám. 1c).- Procede de Pedro Cruzado (Sevilla). Ladrillo completo fragmentado en dos. Dimensiones totales: Longitud: 39 cm.; Ancho: $32 \mathrm{~cm}$;; Grosor: $4 \mathrm{~cm}$. El motivo decorativo central presenta un doble círculo de $17,5 \mathrm{~cm}$. de diámetro relleno con motivos radiadados que encierra un exapétalo. Los pétalos se unen mediante hojas lanceoladas dando lugar a un exágono cóncavo. Estos motivos decorativos centrales están enmarcados en ambos lados por un rebaje sin decoración de 13 $\mathrm{cm}$. de longitud y $4 \mathrm{~cm}$. de ancho y un espacio con decoración ajedrezada de $7,5 \mathrm{~cm}$. de longitud y $4 \mathrm{~cm}$. de ancho.

Ladrillo n. ${ }^{\circ}$ 4.- (Fig. 1d. Lám. 2a).- Procede de El Rubio, Sevilla (plano 3). El lugar del hallazgo se encuentra próximo al pueblo de Marinaleda. Entre las carreteras que van a Estepa, Ecija, Osuna y Aguaduice. Próximo a la central lechera Vega e Hijo se encuentra un cortijo y a $800 \mathrm{~m}$. de este se halla un pequeño otero en donde pudieron documentarse los restos de un edificio. A través del croquis que nos proporcionó D. Ricardo Marsall, podemos observar que este estaba construído con paramentos de piedras irregulares que alternaban con otros realizados en ladrillo. Junto a los ladrillos decorados que generalmente aparecieron boca abajo y con una capa de cal de $8 \mathrm{~cm}$. de espesor, se documentaron otros elementos constructivos: una basa de columna, dos capiteles (no se especifica el orden arquitectónico) y un fuste de columna (plano 4). Ladrillo completo. 


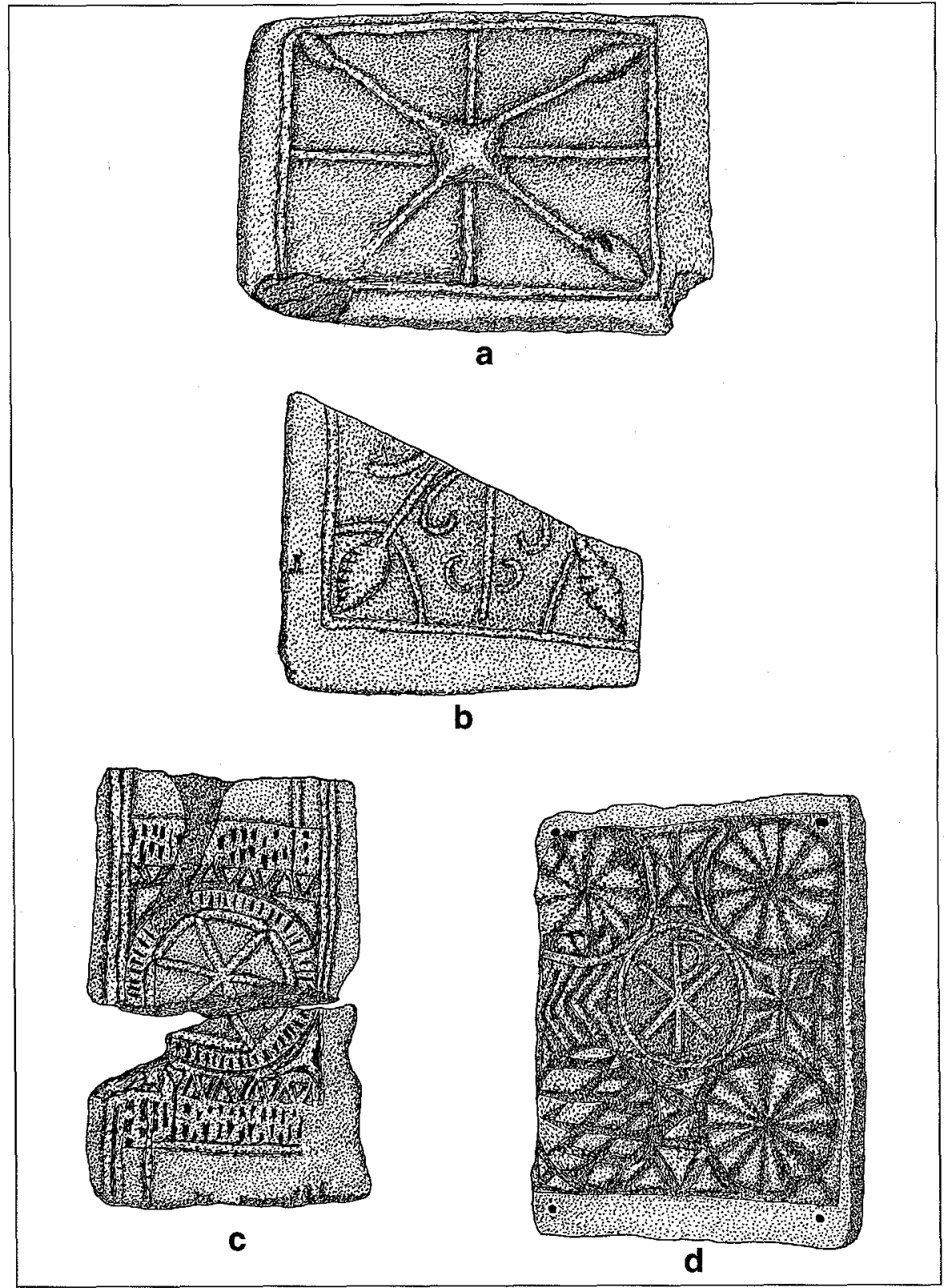

Figura 1. Ladrillos de la Colección Alhonoz: a) Ladrillo n. 1 Herriza del Ciervo; b) Ladrillo n. 2 Pedro Cruzado; c) Ladrillo n. ${ }^{\circ} 3$ Pedro Cruzado; d.) Ladrillo n. ${ }^{\circ} 4$ El Rubio (Sevilla). (Dibujos J. Mellado). 


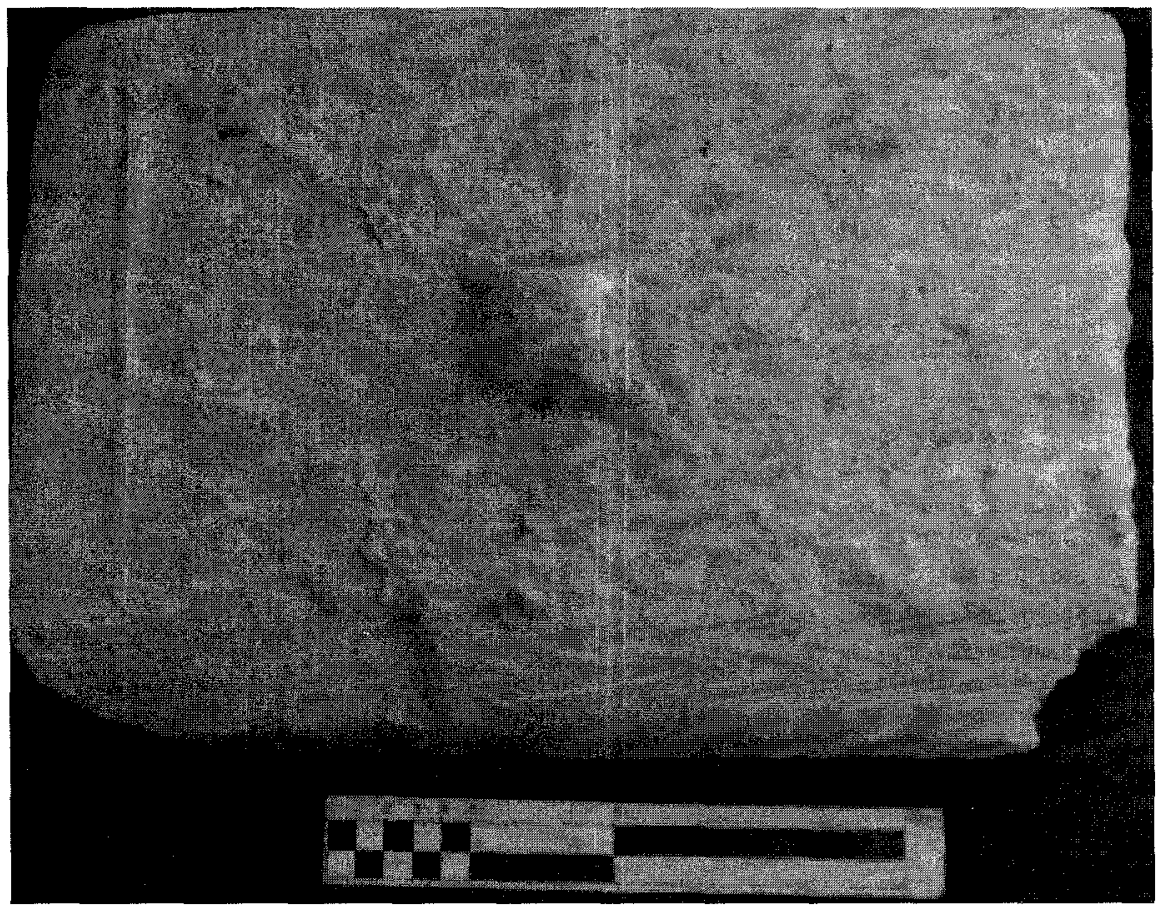

a

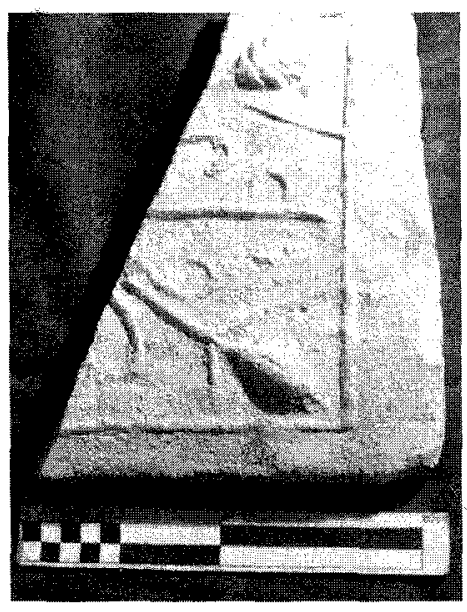

b

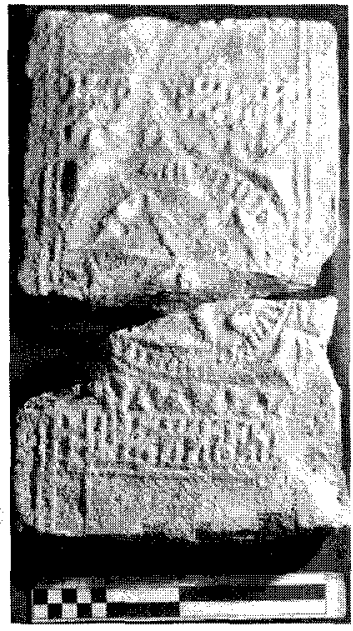

C

Lámina 1. Ladrillos de la Colección Alhonoz: a) Ladrillo n. 1 Herriza del Ciervo; b) Ladrillo $n .^{\circ} 2$ Pedro Cruzado; c) Ladrillo $n .^{\circ} 3$ Pedro Cruzado. 


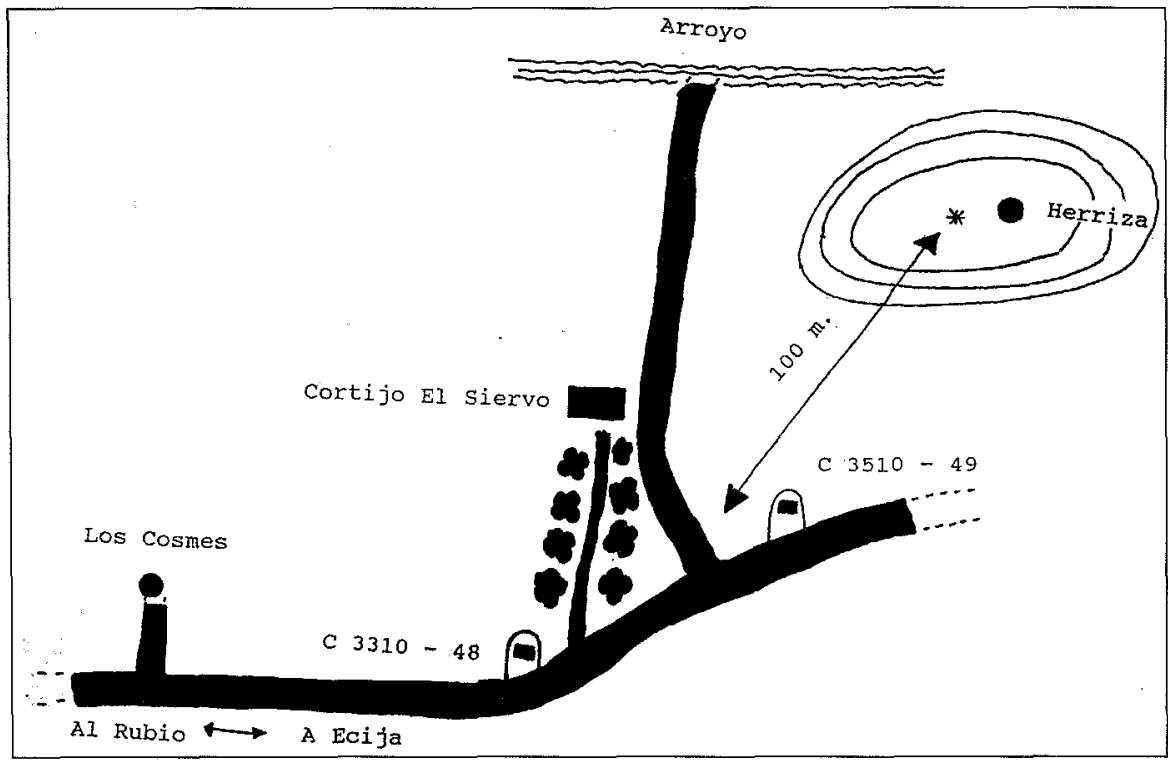

Plano 1. Ubicación del hallazgo realizado en Herriza del Ciervo (Sevilla).

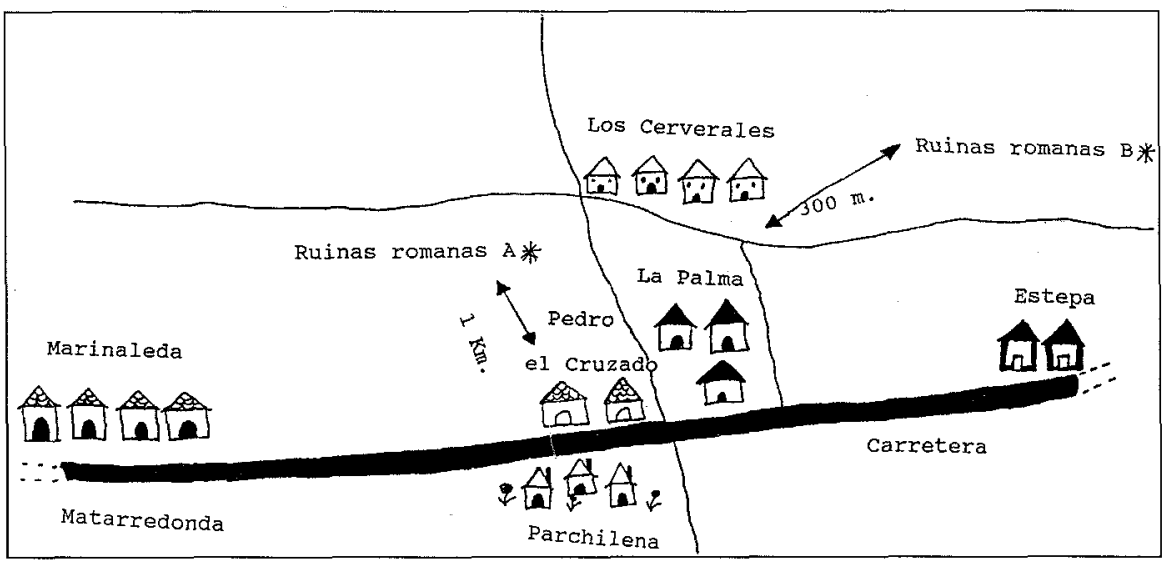

Plano 2. Ubicación de los hallazgos realizados en Pedro Cruzado (Sevilla).

Dimensiones: Longitud: $41 \mathrm{~cm}$; Ancho: $33 \mathrm{~cm}$; Grosor: $3 \mathrm{~cm}$. Presenta un orificio en cada una de las esquinas. La decoración está enmarcada por un recuadro que corre a $1 \mathrm{~cm}$. por los lados más largos y a $3 \mathrm{~cm}$. por los lados más cortos. Tres de las esquinas del ladrillo están ocupadas por un círculo que enmarca un motivo aspado, las aspas varían en número y sue- 


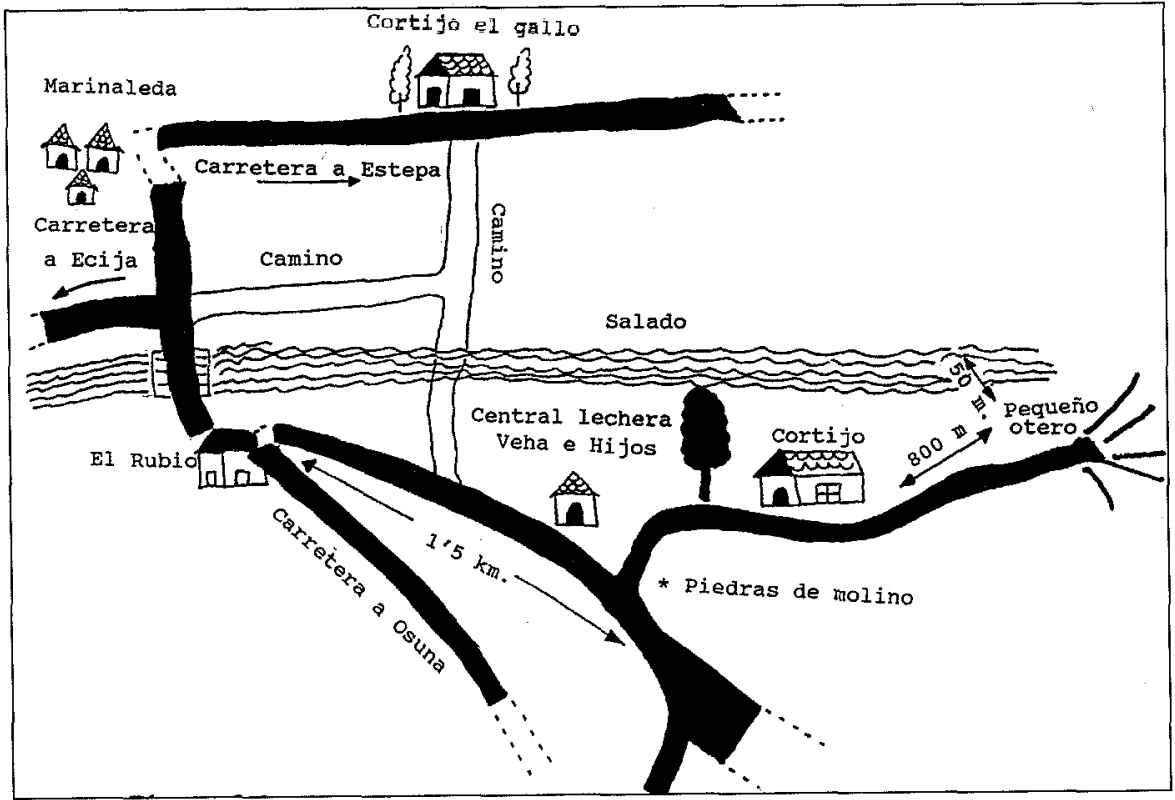

Plano 3. Ubicación de los hallazgos realizados en el Rubio (Sevilla).

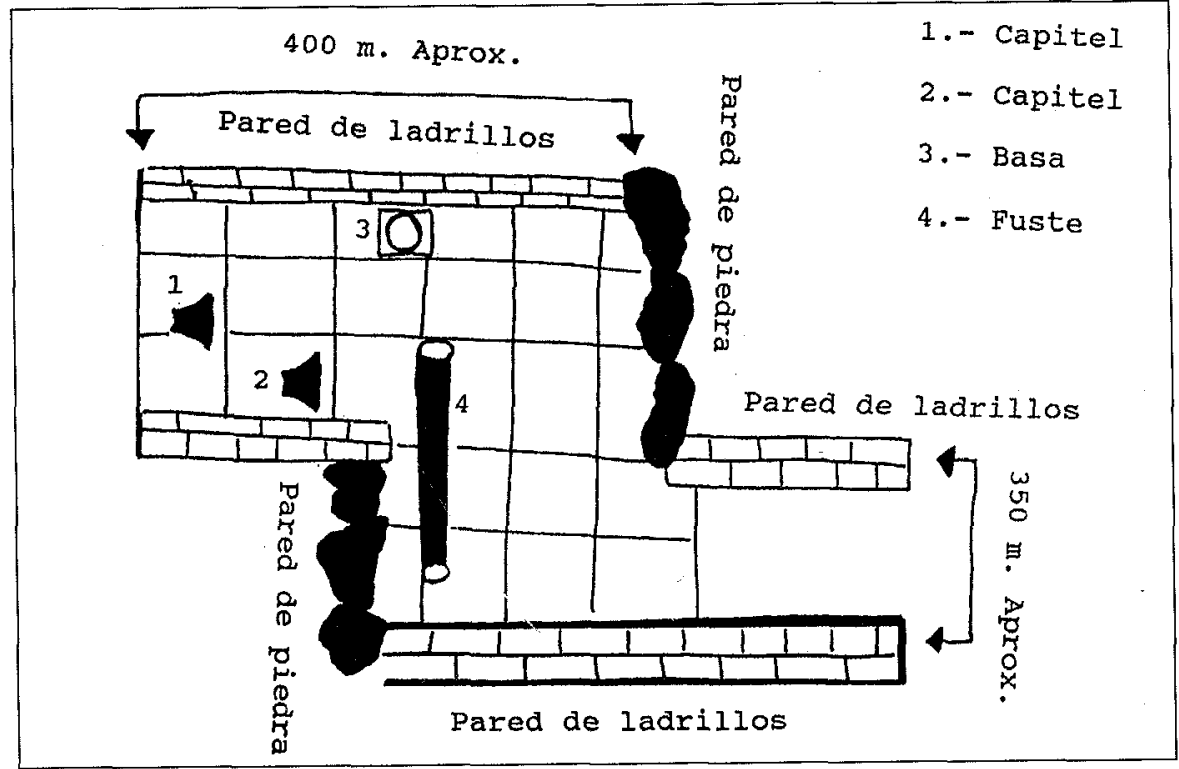

Plano 4. Croquis del edificio donde se localizan los ladrillos de El Rubio (Sevilla). 
len formar una roseta de 12, 10 y 12 pétalos; la cuarta está ocupada por rombos también encerrados en un círculo. En el centro presenta como motivo decorativo un crismón formado por las letras « $X » y$ « $P »$, encerrado en una circunferencia de $13,5 \mathrm{~cm}$. de diámetro. Entre los círculos de las esquinas y el central se desarrollan dibujos diferentes: espigas, temas diagonales que se cruzan en el centro y líneas en zig-zag que separan triángulos abultados.

Ladrillo n. ${ }^{\circ}$ 5. (Lám 2b). Procede de El Rubio (Sevilla). Ladrillo completo. No presenta los orificios de las esquinas documentados en el ejemplar $n .^{\circ} 4$. Dimensiones: Longitud: $40,5 \mathrm{~cm}$.; Ancho: $31 \mathrm{~cm}$.; Grosor: $3 \mathrm{~cm}$. La decoración es exactamente igual a la que presenta el ladrillo $n .^{\circ} 4$. Los dos ejemplares $\left(n .^{\circ} 4\right.$ y $n .^{\circ}$ ) presenta la misma decoración que un ejemplar recogido por L. Fariña Couto: "ladrillo de procedencia desconocida con crismón en el centro. Foto del Laboratorio de Arte de la Facultad de Filosofía y Letras de la Universidad de Sevilla. Crismón en el centro de un círculo. Faltan el «Alfa» y la «Omega». En cada esquina presenta un florón dentro de un círculo a excepción del círculo inferior izquierdo que en lugar de roseta presenta un escamado. Entre estos círculos hay dibujos diferentes; entre los laterales izquierdos lineas quebradas. Entre los derechos diagonales que se cruzan en el centro, igual a éste es el que ocupa el espacio superior siendo el del inferior una línea en zig-zag que separa triángulos abultados" (19339-1940, p. 207. Lám. VIII).

Palol cita dos piezas idénticas conservadas en el Museo Arqueológico Nacional de Madrid, proceden de la Colección Caballero Infantes y fueron publicados por primera vez (1876) por Rada y Delgado: «Proceden de Espejo o Córdoba. Profusamente decorados con un sentido claro de horror vacui. Tiene cuatro círculos iguales colocados en los ángulos y otro igual, también en el centro. Los de los ángulos decorados con temas geométricos centrales, ya sea en forma de fiores geometrizadas o rueda o pastillas romboidales. El círculo del centro contiene crismón con la letra «Rho» cerrada y sin letras «Alfa» y "Omega». Los cuatro espacios que quedan entre los círculos laterales están decorados enteramente con temas en relieve ya sea de espina de pescado o en temas diagonales, de tal forma que constituyen, unidos y precindiendo de los círculos laterales, una cruz de brazos curvos iguales, con el crismón en el centro. Es una verdadera filigrana, compleja y bárbara, pero que se traduce en un arte preciosista. Los temas, la decoración de claro-oscuro sin talla a bisel nos sugieren temas del siglo $v$ o quizá del vi pero no creemos que sean más tardíos" (1967, p. 261). 


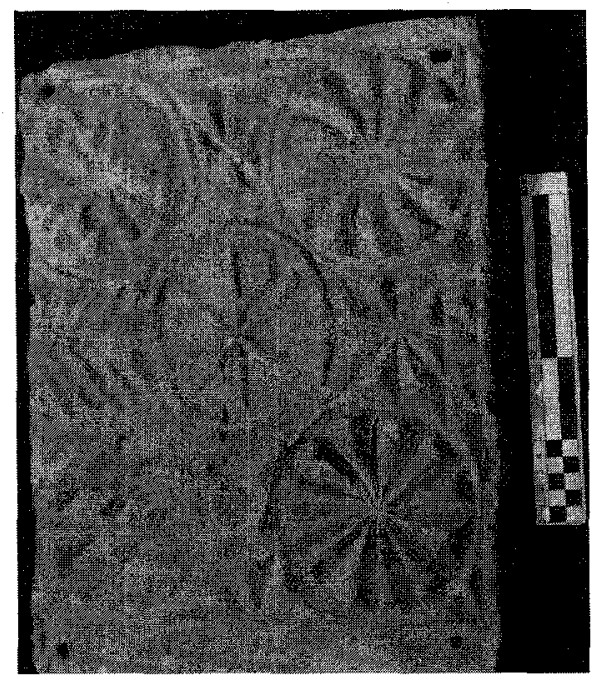

a

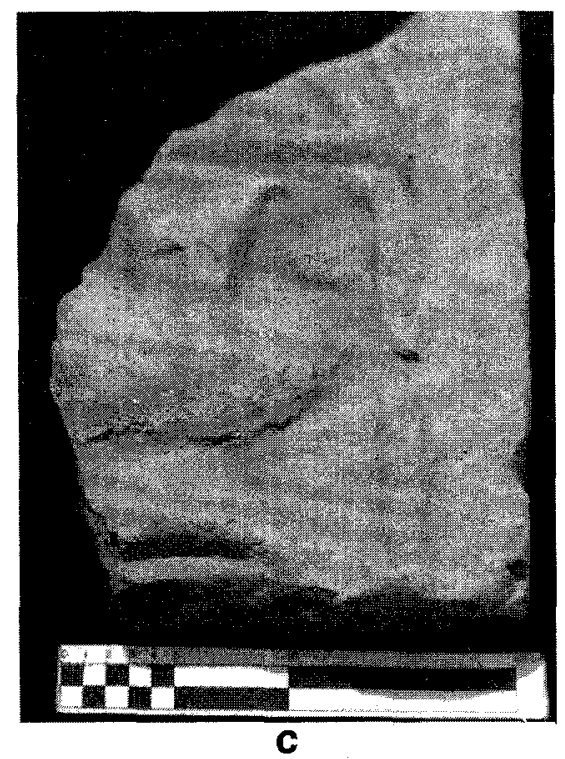

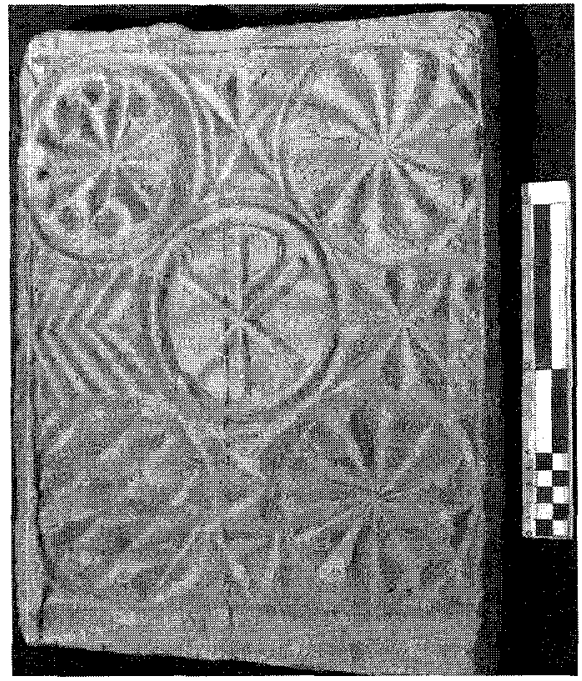

b

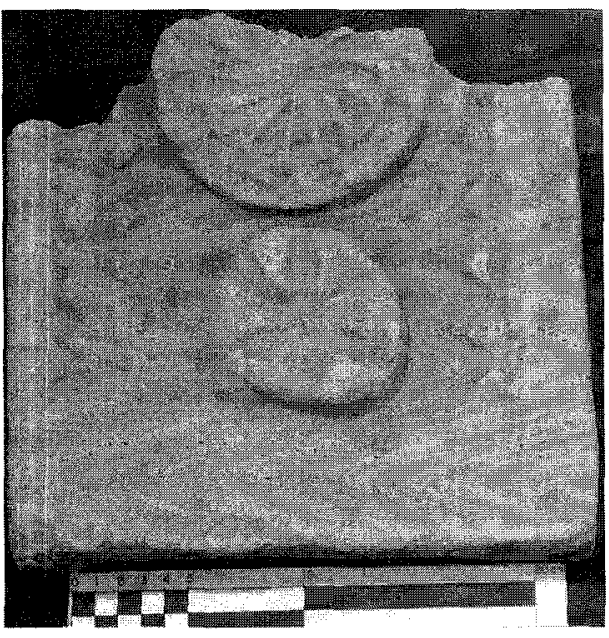

d

Lámina 2. Ladrillos de la Colección Alhonoz: a) Ladrillo n. 4 El Rubio (Sevilla); b) Ladrillo n. ${ }^{\circ} 5$ El Rubio (Sevilla); c) Ladrillo n. 6 Cortijo La Estrella (Posadas, Córdoba) y d) Ladrillo $n .^{\circ} 7$ Cortijo La Estrella (Posadas, Córdoba). 
Rodríguez Berlanga en el Catálogo del Museo Loringiano da a conocer un ejemplar indéntico. Aparece representado en la lámina $n .^{\circ} \mathrm{XXX|X}$ pero no hemos encontrado su descripción en el texto (1909, pp. 126-130).

Ladrillo n. ${ }^{\circ}$ 6. (Fig. 2a y Lám. 2c).- Cortijo de la Estrella, Posadas (Córdoba). Fragmentado. Dimensiones: Longitud: $34 \mathrm{~cm}$; Ancho: $18 \mathrm{~cm}$; Grosor: $5 \mathrm{~cm}$. Presenta una gran crátera agallonada con asas en forma de "S». Está formada por un cuello de $5,5 \mathrm{~cm}$. de alto, cuerpo agallonado de $13 \mathrm{~cm}$. de ancho y $7 \mathrm{~cm}$. de alto. El pie es triangular con base curva de 8 $\mathrm{cm}$. de ancho y $8 \mathrm{~cm}$. de alto. El pie y el cuerpo están incompletos solo se conserva el asa derecha. Este vaso se encuentra colocado debajo de un pórtico. Se conserva la columna formada por una basa muy erosionada, fuste roto en algún tramo y parte del capitel. La altura es de $21,5 \mathrm{~cm}$. Sobre el capitel se apoya un frontón del que solo se conserva la esquina. Palol cita tres ejemplares con decoración semejante. Se conservan en diversas instituciones: en el Museo de Sevilla se conserva un ejemplar completo; en el de Granada un fragmento donde se observa una gran crátera agallonada con asas en "S", colocada debajo de un pórtico semejante al figurado en el grupo de ladrillos de «Bracarius»; el tercer ejemplar procede del Museo de Córdoba (Palol, 1967, pp. 268-269). El autor cree que el tipo de crátera, por su forma agallonada, participa de elementos muy clásicos representados en la serie de mosaicos sepulcrales de origen africano que se han documentado en el sureste español así como en los recipientes figurados en los mosaicos de las basílcas baleáricas. Por todo ello establece una cronología no muy alejada del siglo $\vee$ d.C. (1967, p. 271).

Ladrillo n. ${ }^{\circ}$ 7.- Cortijo La Estrella. Posadas, Córdoba. Fragmento. solo se conserva una esquina. Dimensiones: Longitud: $22 \mathrm{~cm}$.; Ancho: $24 \mathrm{~cm}$; Grosor: $3 \mathrm{~cm}$. Se conserva la esquina de un recuadro formado por dos listeles con motivos cuadrangulares rehundidos tanto en la zona inferior como en el lateral. Junto al listel inferior se han representado triángulos que alternan la posición de los vértices. El motivo central está formado por varios elementos: segmento de circunferencia en su interior presenta dos brazos de una roseta unidos por una hoja lanceolada; pudo tratarse de una roseta exápetala y la hoja lanceolada pudo integrar un exágono que dejaría espacios triangulares. Entre el recuadro de enmarque y el círculo con roseta hay un motivo triangular.

Ladrillo n. ${ }^{\circ}$ 8.- (Fig. 2b y Lám. 2d).- Cortijo La Estrella, Posadas (Córdoba). Fragmento. Dimensiones: Longitud: $20 \mathrm{~cm}$.; Ancho: $25 \mathrm{~cm}$.; grosor: $5 \mathrm{~cm}$. La decoración está enmarcada en sus lados más largos por 
dos filetes. El derecho es liso de $16 \mathrm{~cm}$. de longitud y $1,5 \mathrm{~cm}$. de ancho. Hacia el interior y con la base pegada al filete se conservan cinco triángulos. El filete izquierdo es dentado hacia el exterior; mide $12,5 \mathrm{~cm}$. de longitud y $1 \mathrm{~cm}$. de ancho. Hacia el interior se observan cuatro triángulos. Los motivos centrales consisten en una roseta de 12 pétalos unidos por líneas dando lugar a un círculo. Tanto la roseta como el círculo se encuentran enmarcados por otro motivo circular de $12 \mathrm{~cm}$. de diámetro que presenta en su entorno dientes de lobo. El motivo sobresale $2 \mathrm{~cm}$. con respecto al fondo. El segundo motivo que se conserva una roseta de seis pétalos inscrita en un círculo que sobresale $2,5 \mathrm{~cm}$. con respecto al fondo. Tiene $8 \mathrm{~cm}$. de diámetro.

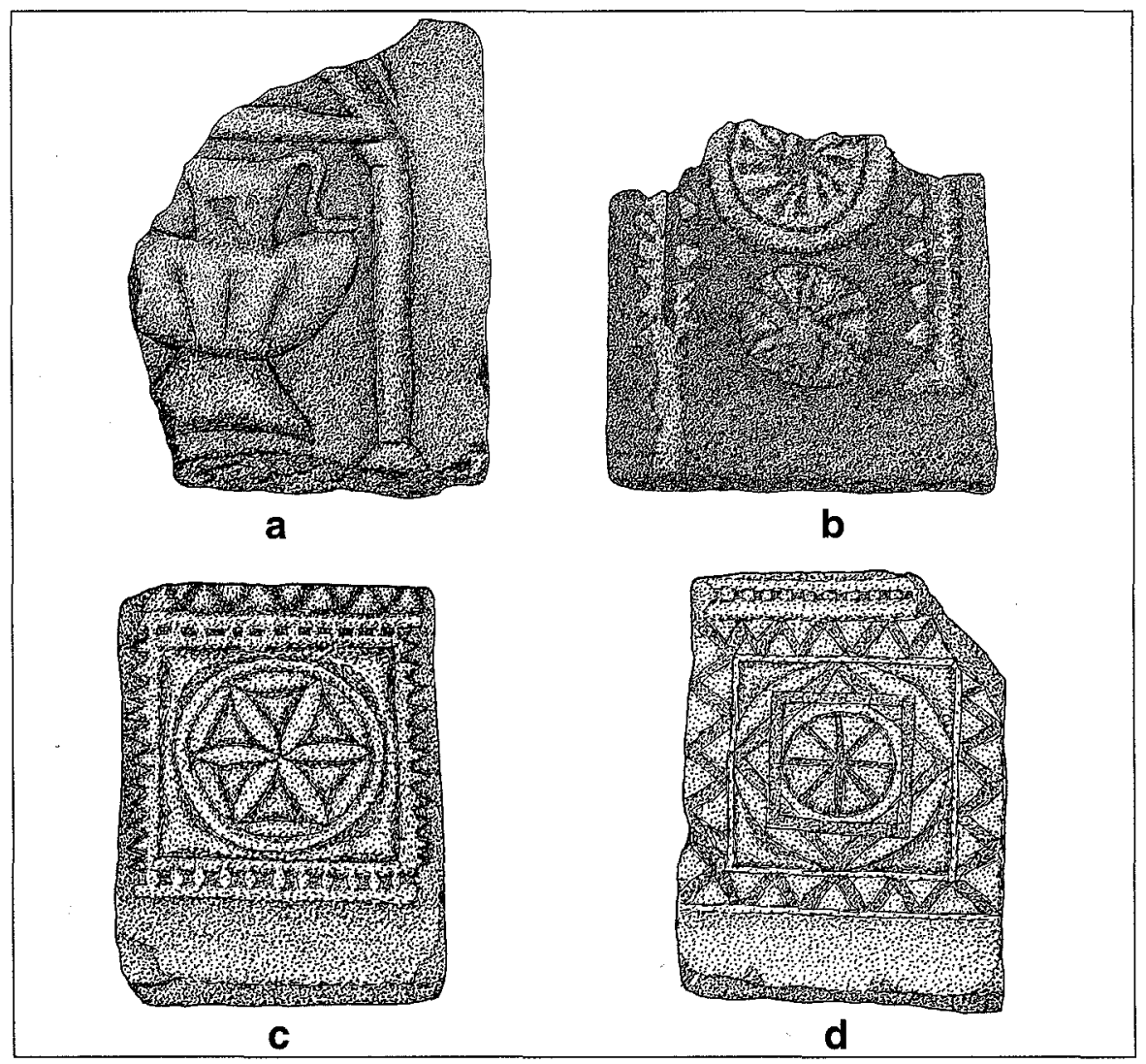

Figura 2. Ladrillos de la Colección Alhonoz: a) Ladrillo n. ${ }^{\circ} 6$ Cortijo La Estrella (Posadas, Córdoba) b) Ladrillo n. ${ }^{\circ} 8$ Cortijo La Estrella (Posadas, Córdoba); c) Ladrillos n. ${ }^{\circ}$ 9-10 Cortijo La Estrella (Posadas) y d) Ladrillos $n .^{\circ} 11-12$ Cortijo La Estrella (Posadas, Córdoba). (Dibujos J. Mellado). 
Ladrillo n. ${ }^{\circ}$ 9.- (Fig. 2c y Lám. 3a).- Cortijo La Estrella, Posadas (Córdoba). Completo. Dimensiones: Longitud: $23 \mathrm{~cm}$. Ancho: $17 \mathrm{~cm}$. Grosor: $4 \mathrm{~cm}$. Presenta una línea de enmarque que corre a $4,5 \mathrm{~cm}$. del borde inferior y a $1,5 \mathrm{~cm}$. del borde superior donde la línea de enmarque remata con dientes de sierra. El espacio que queda entre los dos filetes que forman el recuadro está decorado con líneas paralelas verticales dando lugar a pequeños rectángulos. El espacio cuadrangular central mide $12 \times 13 \mathrm{~cm}$. Los ángulos del cuadrado están ocupados por triángulos en relieve con la base curva. En el interior se ha representado un círculo de $11 \mathrm{~cm}$. de diámetro que encierra en su interior una roseta exapétala. Los pétalos están unidos por hojas lanceoladas que dan lugar a un exágono. El espacio que queda entre las hojas de la roseta está ocupado por un motivo triangular en relieve.

Ladrillo n. ${ }^{\circ}$ 10.- Cortijo La Estrella, Posadas (Córdoba). Fragmento. Dimensiones: Longitud: $16 \mathrm{~cm}$; Ancho: $17,5 \mathrm{~cm}$.; Grosor: $4 \mathrm{~cm}$. Presenta la misma decoración que el ladrillo $n .^{\circ} 9$. Ambos ejemplares son iguales a las piezas recogidas por L. Fariña Cauto y P. Palol. El primer autor dio a conocer un ejemplar de procedencia desconocida con fotografía del Laboratorio de Arte de la facultad de Filosofía y Letras de Sevilla. Lo incluyó en el grupo «Ladrillos con ornamentación geométrica» (1939-40, p. 206. Lám. III). Por su parte Palol cita (junto a la pieza dada a conocer por Fariña) otros ejemplares de diversas instituciones: dos ladrillos completos y el fragmento de un tercero conservados en el Museo Arqueológico de Córdoba; dos piezas procedentes del Museo de Cervera «Rosácea de seis pétalos y las puntas de ellas unidas entre entre si por trazos curvos, formando un exágono regular; todo ello inscrito entre triangulos o dientes de lobo en relieve»; ejemplar del Museo Monográfico de la necrópolis de Carmona (Sevilla) de procedencia desconocida y por último una pieza conservada en el Museo Arqueológico de Sevilla (1967, p. 258).

Ladrillo n. ${ }^{\circ}$ 11. (Fig. 2d y Lám. 3b). Cortijo La Estrella, Posadas (Córdoba). Completo. Falta la esquina. Dimensiones: Longitud: $23 \mathrm{~cm}$.; Ancho: $17 \mathrm{~cm}$.; Grosor: $4 \mathrm{~cm}$. Los motivos centrales están enmarcados por dientes de sierra. La zona superior del ladrillo está rematado por dos filetes cuyo espacio central está decorado por líneas verticales paralelas que forman pequeños rectángulos. El recuadro central mide $13,5 \times 12 \mathrm{~cm}$. Los ángulos del cuadrado están ocupados por triángulos en relieve con la base curva. En el centro se ha representado un círculo y en el interior de éste dos cuadrados cruzados formando una estrella de ocho puntas. El 


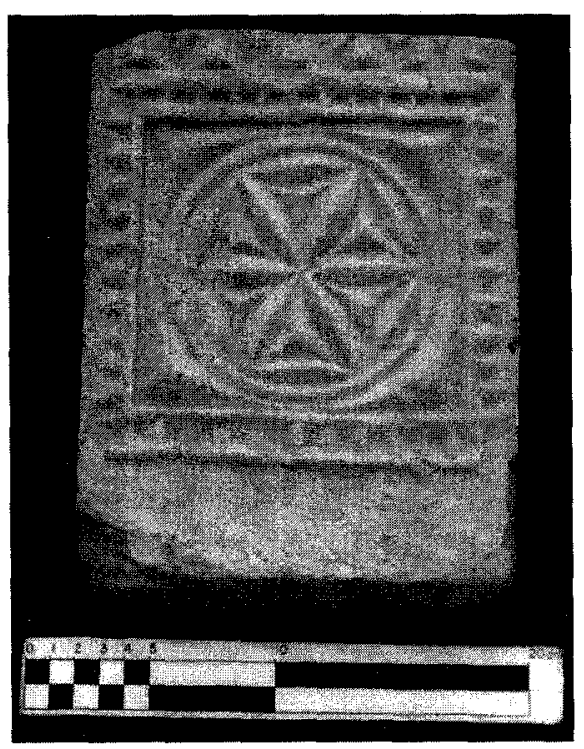

a

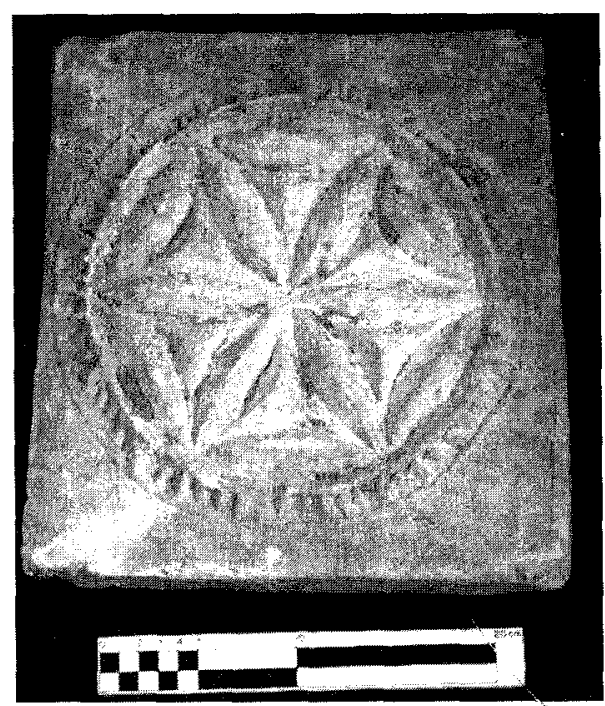

C

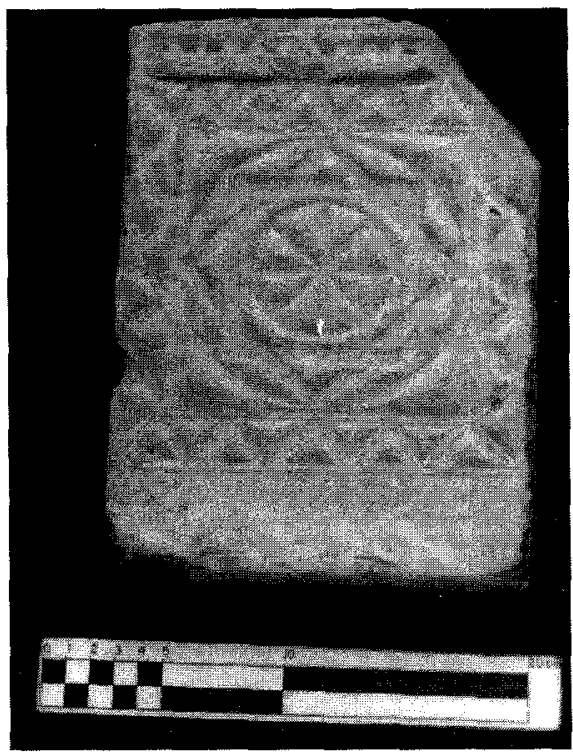

b

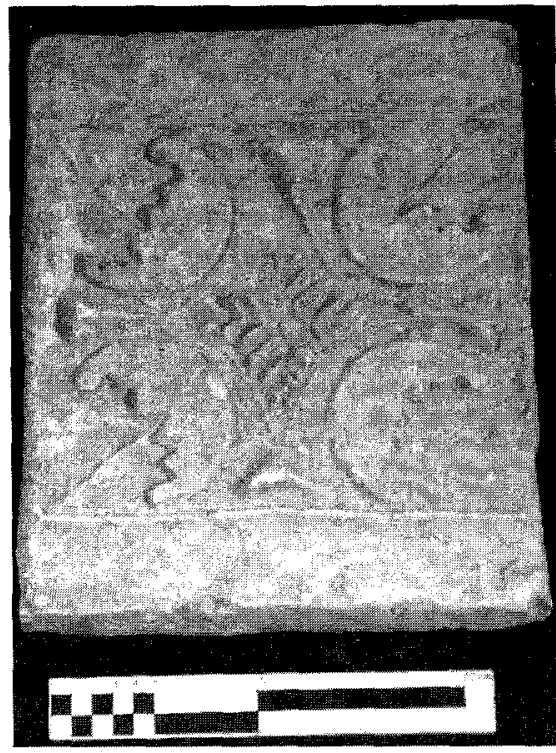

d

Lámina 3. Ladrillos de la Colección Alhonoz: a) Ladrillo n. 9 Cortijo la Estrella (Posadas, Córdoba); b) Ladrillo n. ${ }^{\circ} 11$ Cortijo la Estrella (Posadas, Córdoba); c) Ladrillo n. 13 Torreón de Gerena (Huelva); d) Ladrillo n. ${ }^{\circ} 30$ (Torrón de Gerena, Huelva). 
espacio central se completa con un círculo y una roseta formada por ocho pétalos de forma triángular en relieve.

Ladrillo n. ${ }^{\circ}$ 12.- Cortijo La Estrella, Posadas (Córdoba). Fragmento. Dimensiones: Longitud: $14,5 \mathrm{~cm}$. Ancho: $11,5 \mathrm{~cm}$. Grosor: 3,5 cm. Presenta la misma decoración que el ladrillo $n .^{\circ} 11$. Los ladrillos $n .^{\circ} 11$ y $n . .^{\circ} 12$ son iguales a las piezas recogidas por L. Fariña Couto y $P$. Palol. Fariña lo presenta como un ladrillo de procedencia desconocida con fotografía del Laboratorio de Arte de la Facultad de Filosofía y Letras de Sevilla. Incluído en el grupo de «ladrillos con ornamentación geométrica» (1939-1940, p. 206, Lám. III). Palol lo incluye en el grupo "Círculos cruzados y estrellas o flores». Lo describe en los siguientes términos: «dos cuadros y forma una pequeña flor de ocho pétalos dentro de un círculo en el centro de una estrella que dibujan dos cuadrados entrecruzados alternantes. Todo dentro de un círculo en relieve» $(1967$, p. 258). El autor cree que las estrellas de ocho puntas, algunas veces denominadas como «estrella ibérica» se representa igual en los mosaicos sepulcrales hispano-africanos como por ejemplo en el dedicado a Severina (Denia, Valencia); por esta razón atribuye al ladrillo una cronología del siglo $\vee$ d.C. (1967, p. 271).

Ladrillo n. ${ }^{\circ}$ 13.- (Fig. 3a y Lám. 3c). Torreón de Gerena, Huelva. (plano 5). El Torreón está situado a $5 \mathrm{Km}$. de Gerena y a $23 \mathrm{~km}$. de Olivares. El lugar del hallazgo se encuentra a $500 \mathrm{~m}$. del Torreón. Completo. Dimensiones: Longitud: $31 \mathrm{~cm}$; Ancho: $28 \mathrm{~cm}$.; Grosor: $2 \mathrm{~cm}$. Presenta como motivos decorativos dos círculos concéntricos; el exterior de $25 \mathrm{~cm}$. de diámetro y el interior de $22 \mathrm{~cm}$. El espacio que queda entre los dos círculos concéntricos está ocupado por dientes de lobo. El motivo central consiste en una roseta exapétala de hojas lanceoladas unidas entre sí por hojas lanceoladas que forman un exágono. El espacio que se origina entre pétalo y pétalo está ocupado por un motivo triangular en relieve.

Ladrillo n. ${ }^{\circ}$ 14.- Torreón de Gerena (Huelva). Completo. Dimensiones: Longitud: $32 \mathrm{~cm}$.; Ancho: $28 \mathrm{~cm}$. y Grosor; $2 \mathrm{~cm}$. Misma decoración que el ladrillo $n .^{\circ} 13$.

Ladrillo n. ${ }^{\circ}$ 15.- Torreón de Gerena (Huelva). Completo. Dimensiones: Longitud: $31 \mathrm{~cm}$.; Ancho: $28 \mathrm{~cm}$. y Grosor; $3 \mathrm{~cm}$. Misma decoración que el ladrillo $\mathrm{n} .^{\circ} 13$.

Ladrillo n. ${ }^{\circ}$ 16.- Torreón de Gerena (Huelva). Completo. Dimensiones: Longitud: $31 \mathrm{~cm}$.; Ancho: $28 \mathrm{~cm}$. y Grosor; $3 \mathrm{~cm}$. Misma decoración que el ladrillo $n .^{\circ} 13$. 


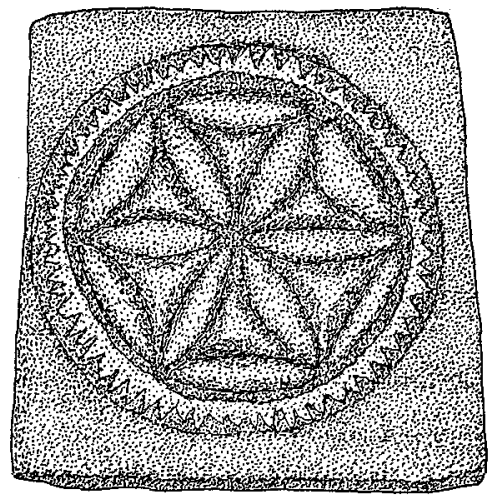

a

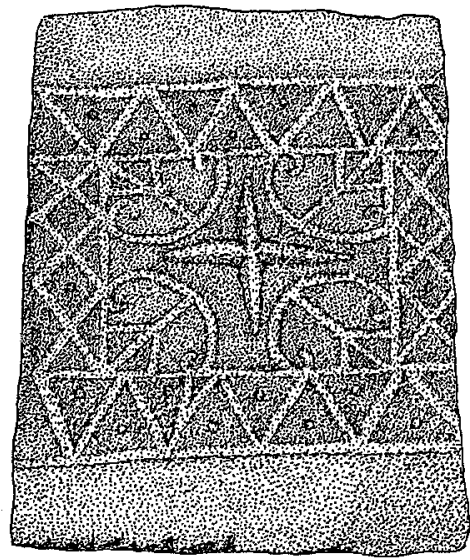

C

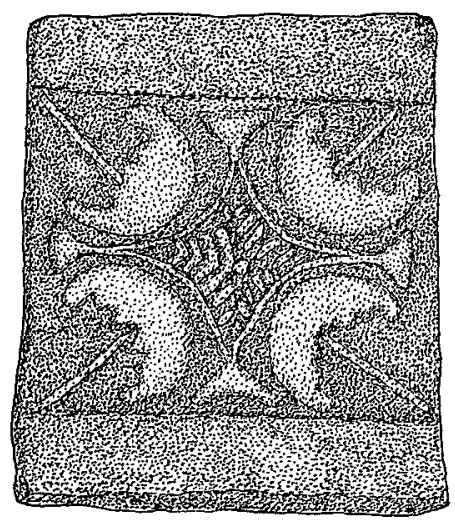

b

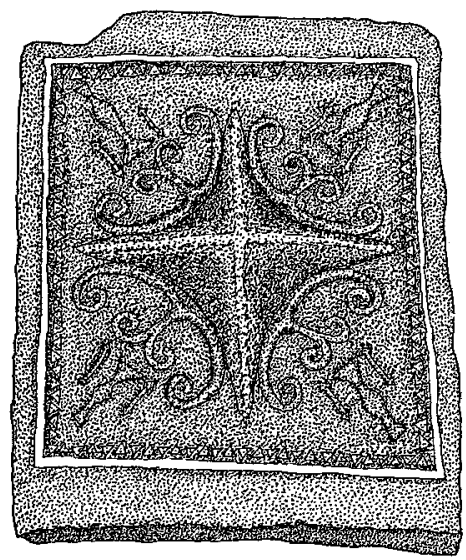

d

Figura 3. Ladrillos de la Colección Alhonoz: a) Ladrillos n. ${ }^{\circ}$ 13-29 Torreón de Gerena (Huelva); b) Ladrillos n. ${ }^{\circ}$ 30-62 Torreón de Gerena (Huelva); c) Ladrillos $n .^{\circ}$ 63-65 Depuradora Campanario; d) Ladrillo n. ${ }^{\circ} 66$ Viso del Marqués. (Dibujo J. Mellado).

Ladrillo n. ${ }^{\circ}$ 17.- Torreón de Gerena (Huelva). Completo. Dimensiones: Longitud: $32 \mathrm{~cm}$.; Ancho: $26 \mathrm{~cm}$. y Grosor; $3 \mathrm{~cm}$. Misma decoración que el ladrillo $n .^{\circ} 13$.

Ladrillo n. ${ }^{\circ}$ 18.- Torreón de Gerena (Huelva). Completo. Dimensiones: Longitud: $33 \mathrm{~cm}$.; Ancho: $27 \mathrm{~cm}$. y Grosor; $3 \mathrm{~cm}$. Misma decoración que el ladrillo $\mathrm{n} .^{\circ} 13$. 


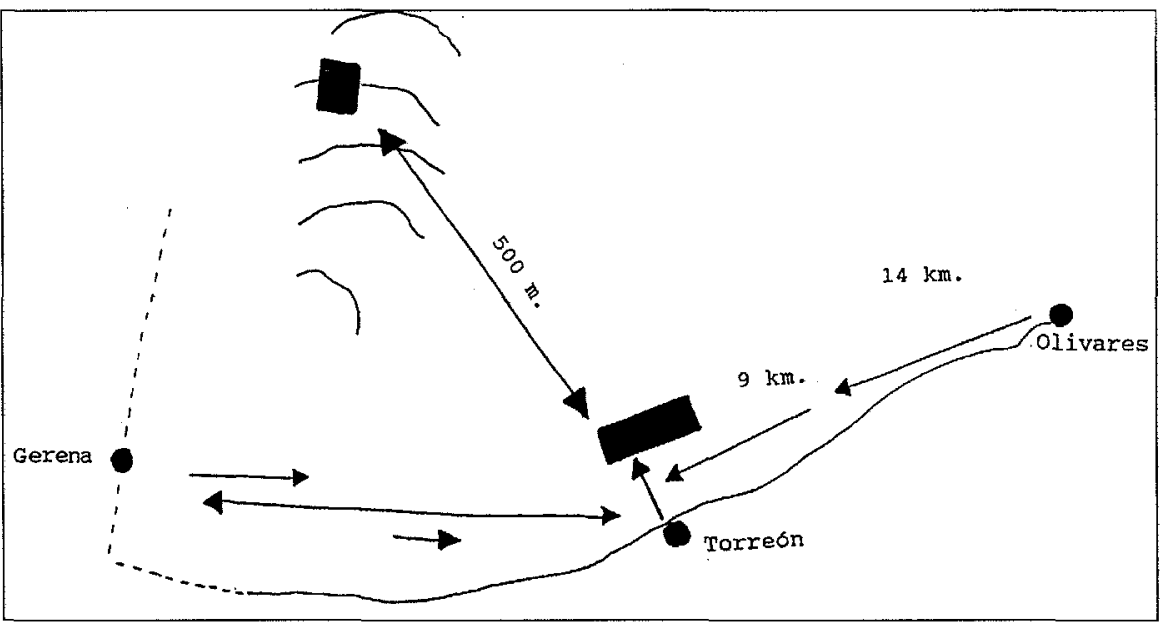

Plano 5. Ubicación de los hallazgos realizados en el Torreón de Gerena (Sevilla).

Ladrillo $n .{ }^{\circ}$ 19.- Torreón de Gerena (Huelva). Completo. Dimensiones: Longitud: $31 \mathrm{~cm}$.; Ancho: $26,5 \mathrm{~cm}$. y Grosor; $3 \mathrm{~cm}$. Misma decoración que el ladrillo $n .^{\circ} 13$.

Ladrillo $n .^{\circ}$ 20.- Torreón de Gerena (Huelva). Completo. Dimensiones: Longitud: 29,5 cm.; Ancho: $27 \mathrm{~cm}$. y Grosor; $3 \mathrm{~cm}$. Misma decoración que el ladrillo $n .^{\circ} 13$.

Ladrillo n. ${ }^{\circ}$ 21.- Torreón de Gerena (Huelva). Completo. Dimensiones: Longitud: 29,5 cm.; Ancho: $17 \mathrm{~cm}$. y Grosor; $3 \mathrm{~cm}$. Misma decoración que el ladrillo $n .^{\circ} 13$.

Ladrillo $n{ }^{\circ}$ 22.- Torreón de Gerena (Huelva). Completo. Dimensiones: Longitud: $32 \mathrm{~cm}$.; Ancho: $14 \mathrm{~cm}$. y Grosor; $3 \mathrm{~cm}$. Misma decoración que el ladrillo $\mathrm{n} .^{\circ} 13$.

Ladrillo $n .^{\circ}$ 23.- Torreón de Gerena (Huelva). Completo. Dimensiones: Longitud: $27 \mathrm{~cm}$.; Ancho: $18 \mathrm{~cm}$. y Grosor; $3 \mathrm{~cm}$. Misma decoración que el ladrillo $\mathrm{n} .^{\circ} 13$.

Ladrillo n. ${ }^{\circ}$ 24.- Torreón de Gerena (Huelva). Completo. Dimensiones: Longitud: 23,5 cm.; Ancho: $19 \mathrm{~cm}$. y Grosor; $3 \mathrm{~cm}$. Misma decoración que el ladrillo $n .^{\circ} 13$.

Ladrillo n. ${ }^{\circ}$ 25.- Torreón de Gerena (Huelva). Completo. Dimensiones: Longitud: $26 \mathrm{~cm}$; Ancho: $15 \mathrm{~cm}$. y Grosor; $3 \mathrm{~cm}$. Misma decoración que el ladrillo $\mathrm{n}^{\circ} 13$. 
Ladrillo n. ${ }^{\circ}$ 26.- Torreón de Gerena (Huelva). Completo. Dimensiones: Longitud: $28 \mathrm{~cm}$.; Ancho: $22 \mathrm{~cm}$. y Grosor; $3 \mathrm{~cm}$. Misma decoración que el ladrillo $\mathrm{n} .{ }^{\circ} 13$.

Ladrillo n. ${ }^{\circ}$ 27.- Torreón de Gerena (Huelva). Completo. Dimensiones: Longitud: $33 \mathrm{~cm}$.; Ancho: $27 \mathrm{~cm}$. y Grosor; $3 \mathrm{~cm}$. Misma decoración que el ladrillo $n .^{\circ} 13$.

Ladrillo n. ${ }^{\circ}$ 28.- Torreón de Gerena (Huelva). Completo. Dimensiones: Longitud: $31 \mathrm{~cm}$.; Ancho: $26 \mathrm{~cm}$. y Grosor; $3 \mathrm{~cm}$. Misma decoración que el ladrillo $\mathrm{n}{ }^{\circ} 13$.

Ladrillo $n .^{\circ}$ 29.- Torreón de Gerena (Huelva). Completo. Dimensiones: Longitud: $32 \mathrm{~cm}$.; Ancho: $29 \mathrm{~cm}$. y Grosor; $3 \mathrm{~cm}$. Misma decoración que el ladrillo $n .^{\circ} 13$.

Ladrillo n. ${ }^{\circ}$ 30.- (Fig. 3b y Lám. 3d).- Torreón de Gerena (Huelva). Completo. Dimensiones: Longitud: $31 \mathrm{~cm}$.; Ancho: $26 \mathrm{~cm}$.; Grosor: $4 \mathrm{~cm}$. Presenta como decoración dos filetes que corren a 4,5 y $5 \mathrm{~cm}$. del borde y delimitan el espacio que va a decorarse. En cada una de las esquinas se sitúa una pelta con borde dentado; de la parte central de la pelta parte una línea que termina en punta de flecha. En cada uno de los cuatro lados se dispone un triángulo, quizá motivo floral geometrizado, del que parten dos tallos divergentes dando lugar a un recuadro de lados cóncavos. Cada uno de los tallos presenta hacia el interior una decoración de líneas oblicuas paralelas dando lugar a una decoración de espigas. El centro está ocupado por una perla o botón.

Ladrillo $n .^{\circ} 31 .-$ Torreón de Gerena (Huelva). Completo. Dimensiones: Longitud: $32 \mathrm{~cm}$.; Ancho: $25 \mathrm{~cm}$.; Grosor: $4 \mathrm{~cm}$. Misma decoración que la pieza $n .^{\circ} 30$.

Ladrillo n. ${ }^{\circ}$ 32.- Torreón de Gerena (Huelva). Completo. Muy erosionado. Dimensiones: Longitud: $31 \mathrm{~cm}$.; Ancho: $26 \mathrm{~cm}$.; Grosor: $4 \mathrm{~cm}$. Misma decoración que la pieza $\mathrm{n} .^{\circ} 30$.

Ladrillo n. ${ }^{\circ}$ 33.- Torreón de Gerena (Huelva). Completo. Muy erosionado. Dimensiones: Longitud: $31 \mathrm{~cm}$; Ancho: $26 \mathrm{~cm}$; Groso: $4 \mathrm{~cm}$. Misma decoración que la pieza $n .^{\circ} 30$. Presenta como anécdota la huella de una pisada de ovicáprido.

Ladrillo n. ${ }^{\circ}$ 34.- Torreón de Gerena (Huelva). Completo. Muy erosionado. Dimensiones: Longitud: $36,5 \mathrm{~cm}$; Ancho: $23,5 \mathrm{~cm}$.; Grosor: $4 \mathrm{~cm}$. Misma decoración que la pieza $n .^{\circ} 30$. 
Ladrillo n. ${ }^{\circ}$ 35.- Torreón de Gerena (Huelva). Completo. Muy erosionado. Dimensiones: Longitud: $31,5 \mathrm{~cm}$.; Ancho: $22,5 \mathrm{~cm}$.; Grosor: $4 \mathrm{~cm}$. Misma decoración que la pieza $\mathrm{n}^{\circ} 30$.

Ladrillo n. ${ }^{\circ}$ 36.- Torreón de Gerena (Huelva). Completo. Muy erosionado. Dimensiones: Longitud: $31 \mathrm{~cm}$.; Ancho: $25 \mathrm{~cm}$.; Grosor: $4 \mathrm{~cm}$. Misma decoración que la pieza $n .^{\circ} 30$. Presenta como anécdota las huellas de los clavos de una sandalia.

Ladrillo n. ${ }^{\circ}$ 37.- Torreón de Gerena (Huelva). Completo. Muy erosionado. Dimensiones: Longitud: $32 \mathrm{~cm}$.; Ancho: 25,5 cm.; Grosor: $4 \mathrm{~cm}$. Misma decoración que la pieza $\mathrm{n} .^{\circ} 30$.

Ladrillo n. ${ }^{\circ}$ 38.- Torreón de Gerena (Huelva). Completo. Muy erosionado. Dimensiones: Longitud: $34 \mathrm{~cm}$.; Ancho: $27 \mathrm{~cm}$.; Grosor: $4 \mathrm{~cm}$. Misma decoración que la pieza $n .^{\circ} 30$.

Ladrillo n. ${ }^{\circ}$ 39.- Torreón de Gerena (Huelva). Completo. Muy erosionado. Dimensiones: Longitud: $33 \mathrm{~cm}$.; Ancho: 26,5 cm.; Grosor: $4 \mathrm{~cm}$. Misma decoración que la pieza $n .^{\circ} 30$.

Ladrillo n. ${ }^{\circ} 40 .-$ Torreón de Gerena (Huelva). Completo. Muy erosionado. Dimensiones: Longitud: $32,5 \mathrm{~cm}$.; Ancho: $26 \mathrm{~cm}$.; Grosor: $4 \mathrm{~cm}$. Misma decoración que la pieza $n .{ }^{\circ} 30$.

Ladrillo n. ${ }^{\circ} 41 .-$ Torreón de Gerena (Huelva). Completo. Muy erosionado. Dimensiones: Longitud: $30 \mathrm{~cm}$.; Ancho: $27 \mathrm{~cm}$.; Grosor: 2,5 cm. Misma decoración que la pieza $n .{ }^{\circ} 30$.

Ladrillo n. ${ }^{\circ}$ 42.- Torreón de Gerena (Huelva). Completo. Muy erosionado. Dimensiones: Longitud: $33 \mathrm{~cm}$.; Ancho: $26 \mathrm{~cm}$.; Grosor: 2,5 cm. Misma decoración que la pieza $n .^{\circ} 30$.

Ladrillo n. ${ }^{\circ}$ 43.- Torreón de Gerena (Huelva). Completo. Muy erosionado. Dimensiones: Longitud: $32 \mathrm{~cm}$.; Ancho: $26 \mathrm{~cm}$.; Grosor: 2,5 cm. Misma decoración que la pieza $\mathrm{n} .^{\circ} 30$.

Ladrillo n. ${ }^{\circ}$ 44.- Torreón de Gerena (Huelva). Completo. Muy erosionado. Dimensiones: Longitud: $33 \mathrm{~cm}$; Ancho: $26 \mathrm{~cm}$.; Grosor: $3 \mathrm{~cm}$. Misma decoración que la pieza $n .^{\circ} 30$. Roto en la esquina superior derecha.

Ladrillo n. ${ }^{\circ} 45 .-$ Torreón de Gerena (Huelva). Completo. Muy erosionado. Dimensiones: Longitud: $33 \mathrm{~cm}$.; Ancho: $26 \mathrm{~cm}$.; Grosor: $4 \mathrm{~cm}$. Misma decoración que la pieza $n .^{\circ} 30$. 
Ladrillo n. ${ }^{\circ} 46 .-$ Torreón de Gerena (Huelva). Completo. Muy erosionado. Dimensiones: Longitud: $33 \mathrm{~cm}$; Ancho: $26 \mathrm{~cm}$; Grosor: $4 \mathrm{~cm}$. Misma decoración que la pieza $n .^{\circ} 30$.

Ladrillo n. ${ }^{\circ}$ 47.- Torreón de Gerena (Huelva). Completo. Muy erosionado. Dimensiones: Longitud: $30 \mathrm{~cm}$.; Ancho: 25,5 cm.; Grosor: $4 \mathrm{~cm}$. Misma decoración que la pieza $n .^{\circ} 30$.

Ladrillo n. ${ }^{\circ}$ 48.- Torreón de Gerena (Huelva). Completo. Muy erosionado. Dimensiones: Longitud: $32 \mathrm{~cm}$.; Ancho: $26 \mathrm{~cm}$.; Grosor: $4 \mathrm{~cm}$. Misma decoración que la pieza $n^{\circ} 30$. Presenta como anécdota las huellas de los clavos de una sandalia. Las huellas de sandalias documentadas tanto en este ejemplar como en el $n .^{\circ} 36$ del catálogo se encuentran representadas en algunos ladrillos procedentes de la necrópolis de San Miguel de Arroyo, estudiada y publicada por P. de Palol: 1.- «Tégulas planas, sin reborde de perfil o sección triangular colocadas a doble vertiente como cubierta del enterramiento $n .^{\circ} 28$ que contenía un esqueleto infantil sin ajuar». Según el citado autor: «las baldosas de cerámica llevan como marca de alfarero, las improntas de dos zapatos, claveteados formando una línea de planta de pie seguida en su perfil, y dos curvas de clavos en la zona de la planta del pie y del talón respectivamente» (Palol, 1969 , p. 132, lám. VI.3); 2.- «Losetas de cerámica rectangulares que miden $46 \times 30 \times 3,5 \mathrm{~cm}$. colocadas en posición vertical, tres de lado y una en cabecera y otra en los pies. No se hallan las de cubierta. Formaban parte del enterramiento $n .^{\circ} 29$, sepultura infantil». La descripción de estas piezas es la siguiente: «baldosas. Se hallan marcadas con la misma planta de pie que las de la tumba anterior, es decir, con todo el perímetro, una línea longitudinal de dedos a talón, y un conjunto de tres clavos simétricamente colocados en ambos lados de ésta línea, en la zona de la planta» (Palol, 1969, p. 132, lám. X).

Ladrillo $n .^{\circ} 49 .-$ Torreón de Gerena (Huelva). Completo. Muy erosionado. Dimensiones: Longitud: $33 \mathrm{~cm}$.; Ancho: $26 \mathrm{~cm}$.; Grosor: $4 \mathrm{~cm}$. Misma decoración que la pieza $n .^{\circ} 30$.

Ladrillo n. ${ }^{\circ}$ 50.- Torreón de Gerena (Huelva). Completo. Muy erosionado. Dimensiones: Longitud: $33 \mathrm{~cm}$.; Ancho: $25 \mathrm{~cm}$.; Grosor: $4 \mathrm{~cm}$. Misma decoración que la pieza $n .^{\circ} 30$.

Ladrillo n. ${ }^{\circ}$ 51.- Torreón de Gerena (Huelva). Mitad de una pieza. Dimensiones: Longitud: 16,5, Ancho: $26 \mathrm{~cm}$., Grosor: $4 \mathrm{~cm}$. Misma decoración que la pieza $n .^{\circ} 30$. 
Ladrillo n. ${ }^{\circ}$ 52.- Torreón de Gerena (Huelva). Mitad de una pieza. Dimensiones: Longitud: $27 \mathrm{~cm}$., Ancho: $20 \mathrm{~cm}$.; Grosor: $4 \mathrm{~cm}$. Misma decoración qué la pieza $n .^{\circ} 30$.

Ladrillo n. ${ }^{\circ}$ 53.- Torreón de Gerena (Huelva). Mitad de una pieza. Dimensiones: Longitud: $27 \mathrm{~cm}$., Ancho: $20 \mathrm{~cm}$., Grosor: $4 \mathrm{~cm}$. Misma decoración que la pieza $n .^{\circ} 30$.

Ladrillo n. ${ }^{\circ}$ 54.- Torreón de Gerena (Huelva). Mitad de una pieza. Dimensiones: Longitud: $25 \mathrm{~cm}$., Ancho: $19 \mathrm{~cm}$., Grosor: $4 \mathrm{~cm}$. Misma decoración que la pieza n. ${ }^{\circ} 30$.

Ladrillo n. ${ }^{\circ}$ 55.- Torreón de Gerena (Huelva). Mitad de una pieza. Dimensiones: Longitud: $26 \mathrm{~cm}$., Ancho: $17 \mathrm{~cm}$., Grosor: $4 \mathrm{~cm}$. Misma decoración que la pieza $n .^{\circ} 30$.

Ladrillo n. ${ }^{\circ}$ 56.- Torreón de Gerena (Huelva). Mitad de una pieza. Dimensiones: Longitud: $18 \mathrm{~cm}$., Ancho: $17 \mathrm{~cm}$., Grosor: $4 \mathrm{~cm}$. Misma decoración que la pieza $n .^{\circ} 30$.

Ladrillo n. ${ }^{\circ}$ 57.- Torreón de Gerena (Huelva). Mitad de una pieza. Dimensiones: Longitud: $27 \mathrm{~cm}$., Ancho: $17 \mathrm{~cm}$., Grosor: $4 \mathrm{~cm}$. Misma decoración que la pieza $n .^{\circ} 30$.

Ladrillo n. ${ }^{\circ}$ 58.- Torreón de Gerena (Huelva). Mitad de una pieza. Dimensiones: Longitud: $29 \mathrm{~cm}$., Ancho: $24 \mathrm{~cm}$., Grosor: $4 \mathrm{~cm}$. Misma decoración que la pieza $n .^{\circ} 30$.

Ladrillo n. ${ }^{\circ}$ 59.- Torreón de Genera (Huelva). Mitad de una pieza. Dimensiones: Longitud: $28 \mathrm{~cm}$., Ancho: $25 \mathrm{~cm}$., Grosor: $4 \mathrm{~cm}$. Misma decoración que la pieza $n .^{\circ} 30$.

Ladrillo $n .^{\circ} 60,61,62 .-$ Torreón de Genera (Huelva). Fragmentos muy pequeños. Misma decoración que la pieza $n{ }^{\circ} 30$.

Ladrillo n. ${ }^{\circ}$ 63. (Fig. 3c. Lám. 4a).- Hallado en la Depuradora Campanario. Fragmentado en la esquina superior derecha. Dimensiones: Longitud: $39 \mathrm{~cm}$; Ancho:30 cm. y Grosor: $3,5 \mathrm{~cm}$. Decoración erosionada. La decoración central está enmarcada en los lados menores por dientes de sierra formados por triángulos equiláteros decorados con un punto central. En los lados mayores, la decoración consiste en línea de cuadrados sobre la punta tangentes formando relojes de arena. Los cuadradros centrales presentan un punto central. El recuadro central presenta $20 \mathrm{~cm}$. de ancho. En las cuatro esquinas se sitúan arcos con volutas opuestas. De su parte central parte una línea que al llegar a la esquina se divide en 


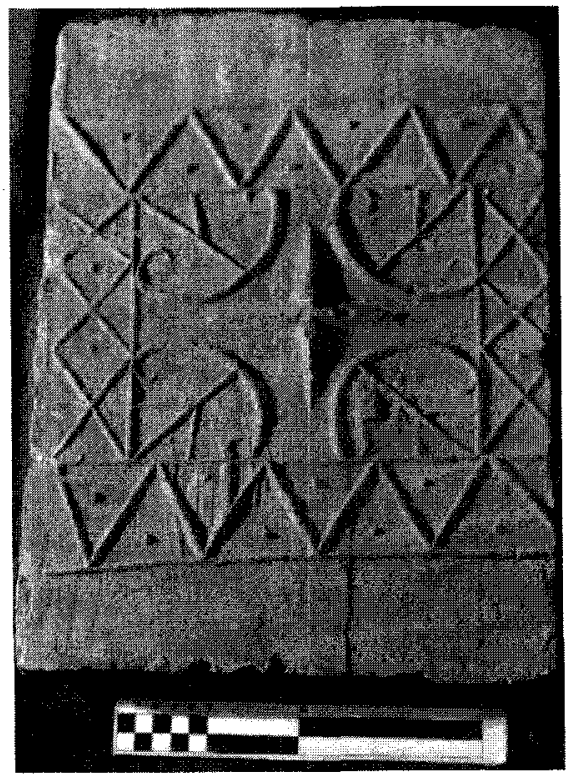

a

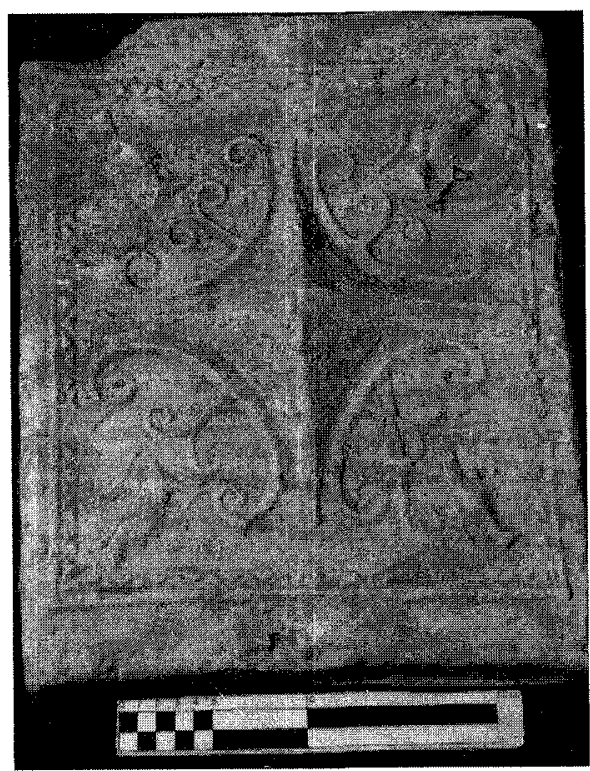

b

Lámina 4. Ladrillos de la Colección de Alhonoz: a) Ladrillo $n .{ }^{\circ} 63$ Depuradora Campanario; b) Ladrillo n. ${ }^{\circ} 66$ Viso del Alcor (Sevilla). 
dos. El espacio que queda en el centro se decora con una estrella de cuatro puntas.

Ladrillo $\mathrm{n} .^{\circ}$ 64.- Hallado en la Depuradora Campanario. Completo. Dimensiones: Longitud: $39 \mathrm{~cm}$.; Ancho: $30 \mathrm{~cm}$.; Grosor: $3 \mathrm{~cm}$. Misma decoración que la pieza $n .{ }^{\circ} 63$. Los motivos decorativos están desviados del centro.

Ladrillo n. ${ }^{\circ}$ 65.- Hallado en la Depuradora Campanario. Completo. Dimensiones: Longitud: $40 \mathrm{~cm}$.; Ancho: $29 \mathrm{~cm}$.; Grosor: $3 \mathrm{~cm}$. Misma decoración que la pieza $n .^{\circ} 63$ del catálogo.

Ladrillo n. ${ }^{\circ}$ 66. (Fig. 3d y Lám. 4b).- Encontrado en Viso del Alcor (Sevilla). Completo. Le falta la esquina izquierda. Dimensiones: Longitud: $39,5 \mathrm{~cm}$.; Ancho: $30 \mathrm{~cm}$.; Grosor: $4 \mathrm{~cm}$. La decoración está enmarcada por un recuadro de $31 \times 27 \mathrm{~cm}$. que corre a $3,5 \mathrm{~cm}$. del borde (en los lados más cortos). Los filetes que forman el recuadro están recorridos en todo su perímetro por pequeños triangulos de bases con sentido contrapuesto. El centro está ocupado por un cuadrado de lados cóncavos. Cada uno de los lados del cuadrado cobija arcos con volutas. Del centro de los arcos parte un capitel eólico y sobre éste se ha representado una crátera de boca triangular, estrecho cuello, panza, pie triangular y dos asas rectas. La parte inferior y superior del asa acaba en motivos triangulares.

Ladrillo n. ${ }^{\circ}$ 67. (Fig. 4a y Lám. 5a).- Viso del Alcor (Sevilla). Fragmentado. Dimensiones: Longitud: $33,5 \mathrm{~cm}$.; Ancho: 34,5 y Grosor: 4 $\mathrm{cm}$. La decoración central está enmarcada en los lados más largos por triángulos de bases contrapuestas y en los más cortos por filetes lisos. A cada lado de los listeles y hacia el borde del ladrillo se ha realizado un motivo de lacerias. El superior se conserva completo mientras que el inferior está fragmentado. El espacio central de $23 \times 25 \mathrm{~cm}$. está ocupado por un cuadrado cóncavo que sobresale mucho en relieve; cada lado curvo está ocupado por arcos con volutas y de su centro parten capiteles eólicos.

Ladrillo n. ${ }^{\circ}$ 68.- Viso del Alcor (Sevilla). Fragmentado. Dimensiones: Longitud: $34,5 \mathrm{~cm}$.; Aricho: $34,5 \mathrm{~cm}$.; Grosor: $3 \mathrm{~cm}$. Presenta la misma decoración que la pieza $n .^{\circ} 67$.

Ladrillo n. ${ }^{\circ}$ 69. (Fig. 4b y Lám. 5b).- Viso del Alcor (Sevilla). Completo. Dimensiones: Longitud: $41 \mathrm{~cm}$.; Ancho: $37,5 \mathrm{~cm}$.; Grosor: $4 \mathrm{~cm}$. La decoración está enmarcada por una doble moldura cuyo espacio central presenta dientes de sierra. El espacio central de $30,5 \times 33 \mathrm{~cm}$. está ocupado por un cuadrado cóncavo de gran relieve con respecto al fondo del ladrillo. 


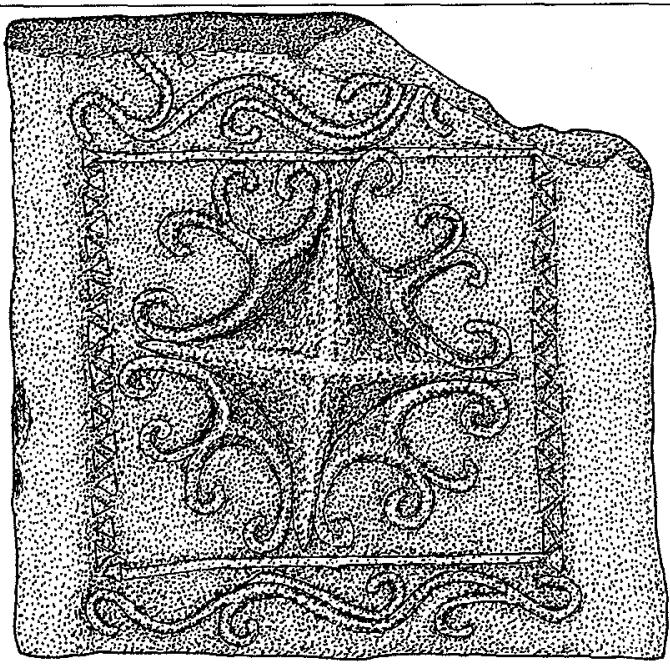

a

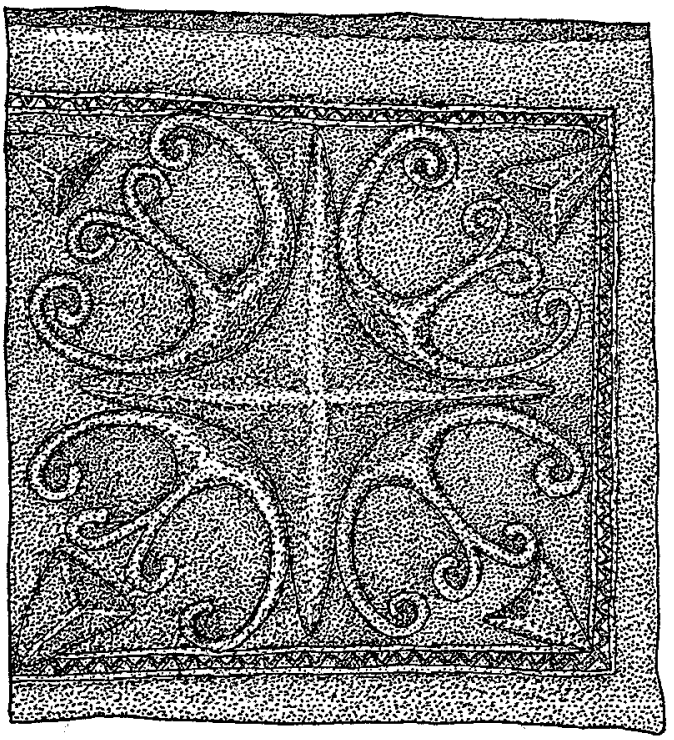

b

Figura 4. Ladrillos de la Colección Alhonoz: a) Ladrillos n. ${ }^{\circ} 67-68$ y b) Ladrillos $n .^{\circ} 69$ 70 Viso del Alcor (Sevilla). (J. Mellado). 


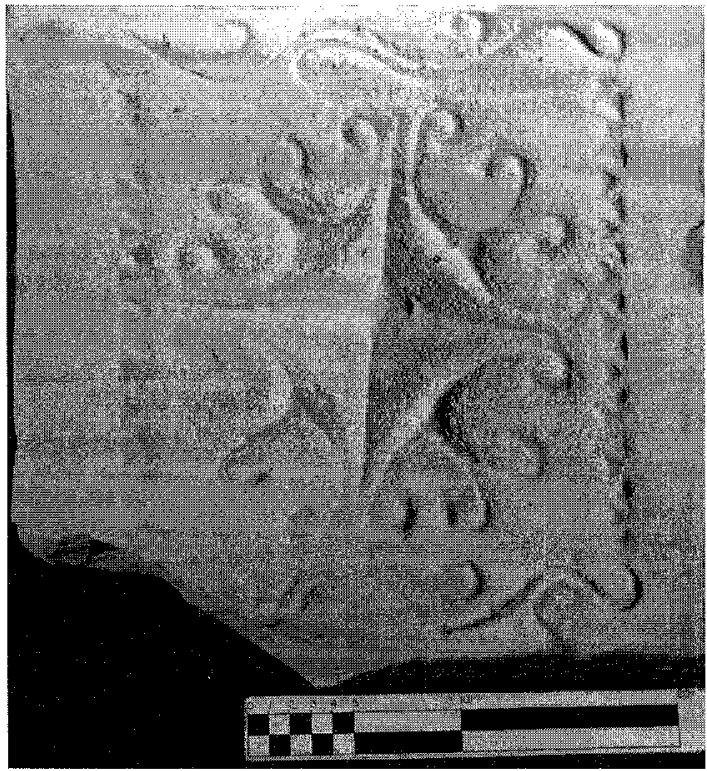

a

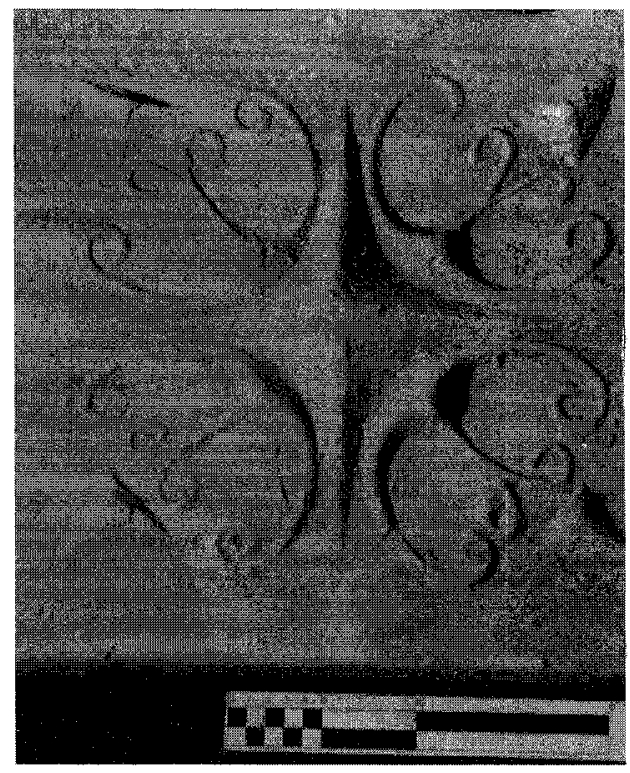

b

Lámina 5. Ladrillos de la Colección Alhonoz: a) Ladrillo n. ${ }^{\circ} 67$ Viso del Alcor (Sevilla); b) Ladrillo.$^{\circ} 69$ Viso del Alcor (Sevilla). 
Cada lado del cuadrado está ocupado por arcos con volutas, de éstos parten capiteles eólicos, sobre ellos se han representado triangulos que coinciden con la esquina del ladrillo.

Ladrillo n. ${ }^{\circ}$ 70.- Viso del Alcor (Sevilla). Completo. Dimensiones: Longitud: $41 \mathrm{~cm}$.; Ancho: $37,5 \mathrm{~cm}$.; Grosor: $4 \mathrm{~cm}$. Misma decoración que la pieza n. ${ }^{\circ} 69$.

Ladrillo n. ${ }^{\circ}$ 71. (Fig. 5a. Lám. 6a).- Viso del Alcor (Sevilla). Completo. Dimensiones: Longitud: $33 \mathrm{~cm}$.; Ancho: $24,5 \mathrm{~cm}$.; Grosor: $3 \mathrm{~cm}$. Presenta como decoración una fachada arquitectónica formada por dos columnas integradas por basa trapezoidal y pequeña moldura; fuste liso y capitel también trapezoidal. De los capiteles parte un arco de medio punto decorado con venera. Sobre los capiteles se han representado dos delfines. Entre las columnas se aprecia la parte superior de un crismón y las letras Alfa y Omega. En esta ocasión la omega se ha representado con letra mayúscula y no en minúscula como es habitual. En el lado izquierdo, al exterior de la columna se puede leer: «SALVO EPIS", mientras que en el lado derecho no se aprecia ninguna inscripción, tal vez perdida por estar, esta zona muy erosionada.

Ladrillo n. ${ }^{\circ}$ 72. (Fig. 5b y Lám. 6b).- Morón de la Frontera (Sevilla).Completo. Dimensiones: Longitud: $39 \mathrm{~cm}$.; Ancho: $24,5 \mathrm{~cm}$.; Grosor: $3 \mathrm{~cm}$. La decoración consiste en una fachada arquitectónica formada por basa trapezoidal y pequeña moldura, fuste liso y capitel corintio de forma trapezoidal. De los capiteles parte un arco de medio punto decorado con venera. El espacio situado entre las columnas está ocupado por un crismón y las letras alfa y omega, en este caso en miníscula. En la zona inferior y entre las aspas de la letras "X" se han representado dos rosetas de siete pétalos triangulares. Sobre los capiteles y enmarcando el arco se han figurado dos delfines, su cola acaba en forma de tridente, detalle que se aprecia en la representación de la izquierda. En el lado izquierdo y al exterior de la columna se lee «SALVO EPIS» y en el derecho "MARCIANO». Esta inscripción puede restituirse de la siguiente manera "SALVO EPIS(copo)/MARCIANO».

Ladrillo n. ${ }^{\circ}$ 73.- Morón de la Frontera (Sevilla). Completo. Dimensiones: Longitud: $40 \mathrm{~cm}$.; Ancho: $24 \mathrm{~cm}$.; Grosor: $3 \mathrm{~cm}$. Presenta la misma decoración que la pieza $n .^{\circ} 72$.

Ladrillo n. ${ }^{\circ}$ 74.- Morón de la Frontera (Sevilla). Completo. Dimensiones: Longitud: $40 \mathrm{~cm}$.; Ancho: $24,5 \mathrm{~cm}$.; Grosor: $3 \mathrm{~cm}$. Presenta la misma deco- 


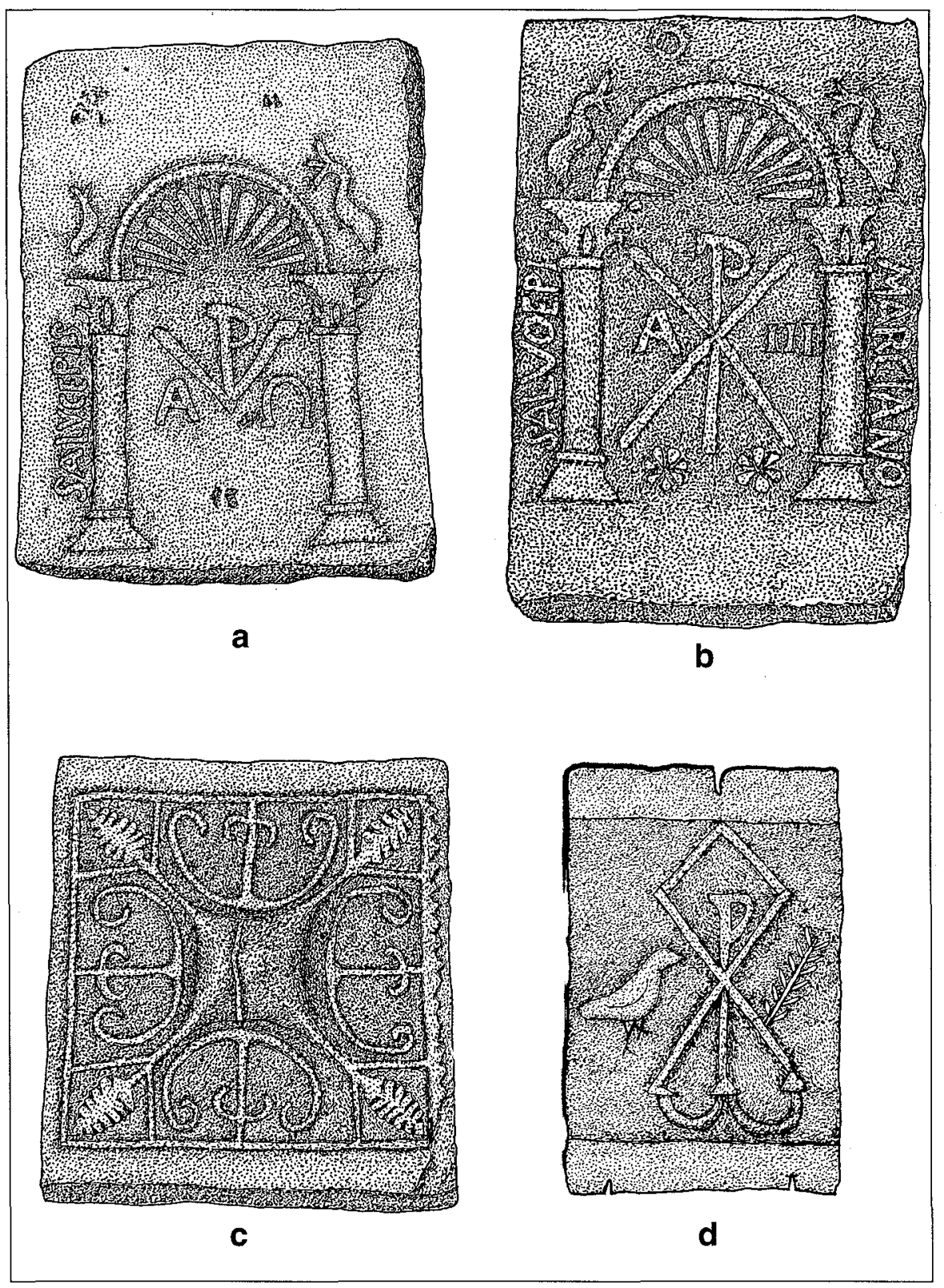

Figura 5. Ladrillos de la Colección Alhonoz: a) Ladrillo n. ${ }^{\circ} 71$ Viso del Alcor (Sevilla); b) Ladrillos n. ${ }^{\circ} 72-74$ Morón (Sevilla); c) Ladrillo $n{ }^{\circ} 75$ Morón (Sevilla); d) Ladrillo n. ${ }^{\circ}$ 79 Colección Fajardo (Osuna, Sevilla). (J. Mellado). 
ración que la pieza $\mathrm{n} .^{\circ} 72$. Piezas idénticas a las número 72,73 y 74 fueron recogidas por F. Fita en 1908; por L. Fariña Couto en 1939-1940 y por Palol (1967). El primer autor cita un ejemplar procedente de Morón de la Frontera (Sevilla) descubierto en el año 1897 en el Cortijo Barbuan, bastante bien conservado. Le otorga una cronología de finales del siglo IV comienzos del siglo v, al identificar a Marciano con un obispo de Sevilla (1908, p. 353). Fariña cita una pieza conservada en la Hispanic Society of New York. Procede de Morón de la Frontera. Se engloba dentro del grupo «Ladrillos en cuyos motivos ornamentales se introducen símbolos o representaciones cristianas". Lo describe en los siguientes términos "dos columnas sostienen un arco semicircular ocupado su tímpano por gallones. El conjunto tiene el aspecto de edícula. El interior está ocupado por crismón con alfa y omega debajo del cual se ven dos rosetas. En las enjutas hay dos delfines. En la parte exterior de las columnas inscripción MARCIANO (derecho) y PIS (izquierdo), interpretada como MARCIANO (hispalensis) (E) Pis(copus) (1939-1940, p. 208). Palol clasifica a estas piezas dentro del grupo «Crismones bajo arco. Grupo Marciano y Bracario». Cree que constituyen el conjunto más numeroso y más bello de las placas de cerámica en relieve de la Bética:” Fueron los primeros que se publicaron. El esquema decorativo es siempre el mismo. Crismón con la letra "Rho" cerrada flanqueada por el alfa y el omega bajo arco de medio punto sostenido por dos columnas con sus correspondientes bases, capiteles y veneras en el arco. En los lados de las columnas se ha colocado la inscripción alusiva. Los recuadros que quedan entre el arco y la línea externa por encima de los capiteles se decoran con una flor de tres pétalos o bien con otros temas distíntos como los delfines. Estos animales parecen proceder de modelos de orfebrería, toreútica o pintura. Son interesantes los capiteles corintios con dos hiladas de hojas muy estilizadas y los basamentos puramente geométricos, con un listel antes de la columna. El grupo de ladrillos de esta forma es muy importante y numeroso. Encontrados siempre en la Bética, el lugar del hallazgo es diverso y a veces distante entre sí». Para Palol la inscripción no tendría un carácter funerario, por lo que el ladrillo no se modelaría para colocarse sobre la tumba del personaje cuyo nombre constaría en la placa. (1967, p. 265). C. Martín Gómez cita un ejemplar similar a los tres ejemplares del catálogo $(72,73$ y 74$)$; se encuentra depositado en el Museo Arqueológicó Provincial de Sevilla. Su procedencia es desconocida. Ingresó en 1970 y fue registrado con el n. 13198 en el Libro Registro de Objeto en Propiedad (1982, pp. 38-39).

Ladrillo n. ${ }^{\circ}$ 75.- (Fig. 5c y Lám. 6c).- Morón de la Frontera (Sevilla). Completo. Dimensiones: Longitud: $30 \mathrm{~cm}$.; Ancho: $30 \mathrm{~cm}$., Grosor: $4,5 \mathrm{~cm}$. 


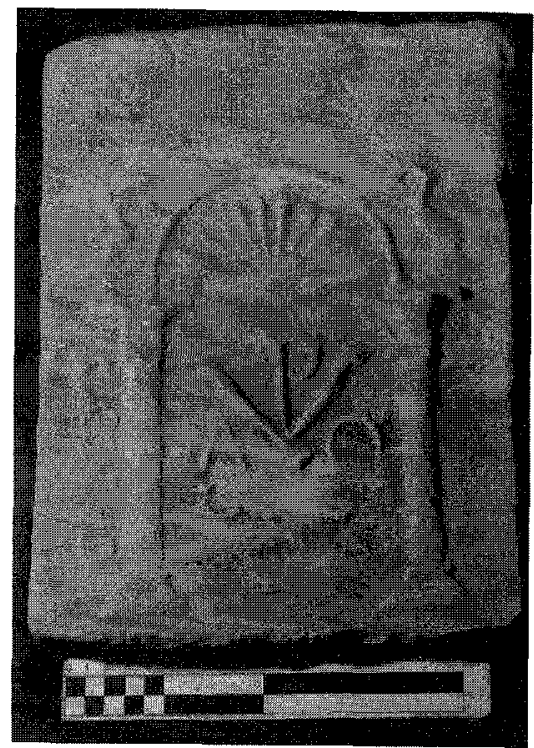

a

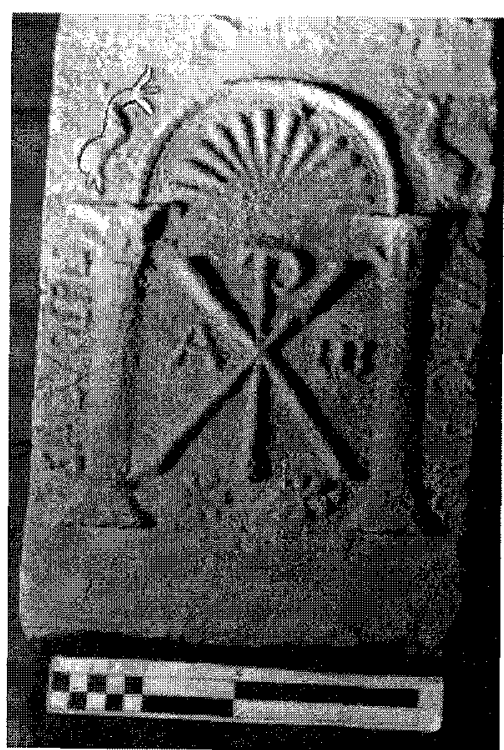

b

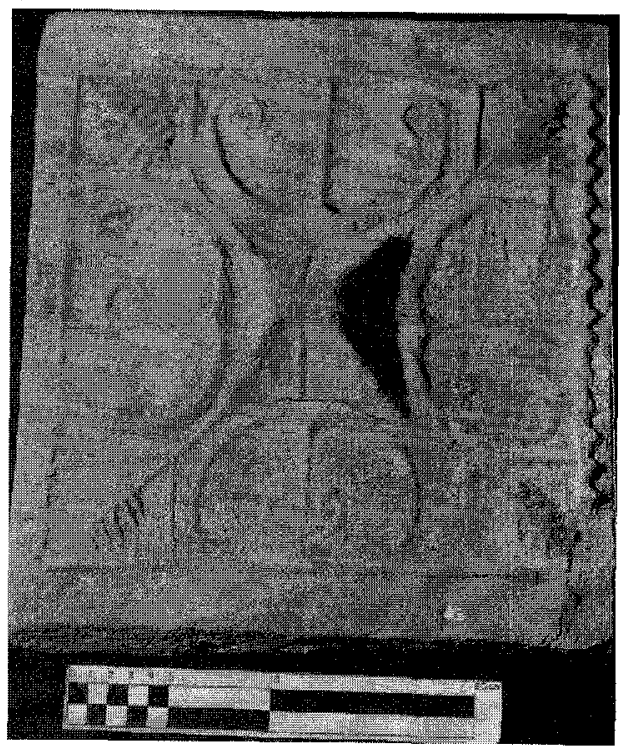

C

Lámina 6. Ladrillo de la Colección Alhonoz: a) Ladrillo n. 74 Viso del Alcor (Sevilla); b) Ladrillo n. 72 Morón (Sevilla); c) Ladrillo n. 75 Morón (Sevilla). 
La decoración central está enmarcada por un recuadro formado por finos filetes, solo dos de los cuatro conserva como motivos decorativos dientes de sierra. El centro presenta un cuadrado de lados curvos. En los lados del cuadrado se han figurado arcos con volutas; de su centro parte un motivo vegetal muy estilizado. De cada una de las esquinas sale un tallo rematado por hojas nervadas.

Ladrillo n. ${ }^{\circ}$ 76.- Procedencia desconocida. Fragmento. Dimensiones: Longitud: 26,5 cm.; Ancho: $20 \mathrm{~cm}$.; Grosor: 2,5 cm. La decoración está muy erosionada. Se adivinan una serie de triangulos que enmarcan una roseta con los triangulos de lados curvos en disposición radial.

Ladrillo n. $^{\circ} 77$.- Cortijo del Coronel (entre Lora del Río y Ecija, Sevilla). Fragmento informe. Dimensiones: $14 \times 12 \times 5 \mathrm{~cm}$. La decoración es difícil de precisar, parece consistir en una circunferencia decorada con dientes de sierra que podría encerrar una roseta.

Ladrillo n. ${ }^{\circ}$ 78.- Cortijo del Coronel (entre Lora del Río y Ecija, Sevilla). Fragmento informe. Dimensiones: $14 \times 13,5 \times 5 \mathrm{~cm}$. Debido al deterioro de la pieza no se puede determinar la decoración.

Ladrillo n. ${ }^{\circ}$ 79. (Fig. 5d) Procede de la Colección Fajardo (Osuna, Sevilla). Completo. Dimensiones: Longitud: $30 \mathrm{~cm}$; Ancho: $21 \mathrm{~cm}$.; Grosor: $4 \mathrm{~cm}$. Presenta como decoración un crismón con las letras alfa y omega superpuestas. Este motivo central está enmarcado por una paloma y una ramita de palma. $M^{a}$.L. Loza Azuaga cita un ejemplar de las mismas características. La autora lo incluye dentro del tipo IV: Placas decoradas con crismones (1991-1992, p. 257. Lám. II.2)

\section{SIMBOLOGÍA DE LOS ELEMENTOS ORNAMENTALES REPRESENTADOS EN LOS LADRILLOS DE LA COLECCIÓN DE ALHONOZ ${ }^{4}$}

1. Alfa y Omega. El mundo cristiano primitivo, al igual que muchas de las culturas antiguas, dieron un valor místico a determinadas letras de su alfabeto. Fue la Dra. Guarducci quien en sus publicaciones sobre los grafitos realizados en el «Muro G» de la Tumba de San Pedro desarrolló de manera sistemática y científica toda una teoría sobre el alcance de la sim-

4 Hemos ordenado los elementos representados en los ladrillos por orden alfabético. 
bología alfabética en el mundo cristiano (Alonso Sánchez, 1982, p. 197). Símbolo cristológico. La primera y última letra del alfabeto griego. Fueron empleadas en la definición que Dios dio de sí mismo en el Apocalipsis de San Juan:» Yo soy el Alfa y el Omega, dice el Señor, el que es, que era y va a venir» $(1,8)$. Cristo repite estas palabras hacia el final de la visión apocalíptica «Yo soy el Alfa y el Omega, el primero y el último, el principio y el fin» $(22,13)$. La primera y última letra del alfabeto griego fueron usadas como expresión de la divinidad de Cristo desde la segunda mitad del siglo II aunque su uso se hizo más común a partir del siglo Iv al acompañar las diversas formas del monograma de Cristo (Kirschbaum et alii, 1954, p. 287). Para Cirlot la letra «alfa» se relaciona con el compás, representación emblemática del acto de la creación y por tanto atributo del dios creador, mientras que la omega se asemeja a una lámpara, al fuego de la destrucción. En el siglo XII en la portada de un manuscrito de Pablo Orosio las dos letras se asocian a animales: pájaro y pez, como abismo superior e inferior (Cirlot, 1985, p. 63).

2. Circunferencia. Para Cirlot el acto de incluir seres, objetos o figuras en el interior de circunferencias tiene un doble sentido: desde dentro implica una limitación y determinación; desde fuera constituye la defensa de los contenidos, así se protegen de los peligros que amenazan desde el exterior que es asimilado al caos y' a los peligros. En virtud de su movimiento, tanto como de su forma, el giro circular tiene además fuerzas establecidas a lo largo del proceso (1985, p. 131)

3. Columna.Pilar. En muchas tradiciones la columna o el pilar pertenecen al grupo cósmico del eje del mundo (árbol, escala, mástil y cruz). Ambos elementos unen y separan simultáneamente el cielo y la tierra. Cuando los israelitas salieron de Egipto para dirigirse a la tierra prometida «... el Señor iba delante de ellos de día en columna de humo para guiarles el camino y de noche en columna de fuego para alumbrarles, de manera que pudieran viajar de dia y de noche» (Exodo 13:21-22); "... Salomón levantó dos columnas de bronce en la entrada al vestíbulo del templo» (I Reyes 7:15-22). Dos columnas o pilares delimitando la entrada o acceso al santuario representan un estado de dualidad que se resuelve con el camino entre ambas que conduce a una nueva idea (Baldock, 1992, 139). En los monumentos cristianos se emplea ordinariamente la columna aislada como símbolo de la Iglesia. Para Cirlot en las alegorias y símbolos gráficos casi nunca aparece una columna sola, sino que son dos. Cuando están colocadas a los lados de un escudo equivalen a los tenentes (fuerzas contrarias en equilibrio tenso). Lo mismo si sostienen un dintel. Los dos pilares 
o columnas simbolizan cosmicamente la eterna estabilidad, su hueco, la entrada a la eternidad. Aluden tambien al templo de Salomón (imagen de la construcción absoluta y esencial). Recoge la idea expresada por Saunier y considera que las dos columnas que se alzan a la entrada de los templos expresan las ideas de evolución e involución, el bien y el mal. En algunas ocasiones esta dualidad se marcaba fisicamente con la distínta naturaleza del material; según las leyendas, en el templo de Hercules en Tiro una de las columnas era de oro y la otra de piedra semipreciosa. En la tradición hebrea las dos columnas se denominan de la Misericordia y del Rigor (1985, p. 141). Para R. Barroso y J. Morín de Pablos la representación de la columna está ligada al crismón y a la cruz. Especifican que el tema de la "columna universal» gozó de cierta fama dentro del mundo visigodo. A través de ella se puede observar el proceso de progresiva esquematización del árbol de la vida y su tranformación en pilar. El paso del árbol a la columna ha de interpretarse como un paso de lo concreto a lo abstracto (1995, p. 9).

4. Conchas o veneras. Símbolo referente a la vida eterna y felicidad celestial, símbolo de la resurreción. La concha es la tumba, una morada momentánea que el hombre debe abandonar un día. La membrana con la que el molusco cierra su entrada en el invierno y que no rompe hasta la primavera representa la tapa del ataúd que debe ser levantada el día de la resurreción. En los sepulcros cristianos se observa con frecuencia la presencia de conchas marinas enteras o rotas fijadas en el exterior de los loculi, quizá como medio de reconocimiento y en el sarcófago de Jonás, conservado en los Museos Vaticanos, hay una escena de pesca en la que también se han fijado diversos tipos de moluscos.

5. Cratera o vaso. Puede ser interpretada de muy diversas formas: 1.- Símbolo de profesión; 2.- Atributo de cargo eclesiastico; 3.- Símbolo del refrigerio del alma cuando va acompañada por pájaros que beben en ella. También puede considerarse como recipiente del agua bautismal y los animales que se acercan a beber en ella simbolizarian a los neófitos que se acercan a la vida de la gracia. Esta representación iconográfica es muy frecuente en la plástica y toreútica visigoda (Barroso Cabrera y Morín de Pablos, 1995, p. 48); 4.- Cuando la crátera va acompañada por palomas, el vaso vacio simboliza el cuepo encerrado en la tumba y las palomas el alma que se escapan de él; 5.- Las delicias del paraiso cuando los vasos están colocados en un bosque florido; 6 .- Símbolo del banquete funerario celebrado en honor al difunto; 7.- Premio otorgado por la victoria obtenida por el hombre viejo; 8.- Alusión al banquete celestial, nada era, en efecto 
más capaz de atenuar la tristeza de la tumba que los símbolos que recordaban a los vivos la dicha celeste en la que creían con toda confianza que eran admitidos los difuntos; 9.- Símbolo del cuerpo humano. San Pablo desarrolla esta teoría en su epístola a los romanos (9: 12 y ss.) y la misma idea la recoge en la carta que dirige a los cristianos de Tesalónica: "....que cada uno de vosotros sepa conservar su vaso en la santificación" (1 Thess. IV,4). Los escritores eclesiásticos, como Tertuliano o Lactancio, emplean frecuentemente esta figura: «el cuerpo es como un vaso que el alma celestial usa como pasajera morada»; 10.- También pudieron tener una significación eucarística (Martigny, 1894, 824-825).

6. Crismón. Signo cristológico. Representa a un mismo tiempo el nombre de Jesucristo y la figura de su cruz. Conocido como Monograma Constantiniano o «Signum Christi». Su forma primitiva lo constituyen dos letras "Chi» $y$ "Rho", las dos primeras letras de la palabra "XPIÇTOÇ», participio del verbo "XPIO» que significa «ungir» por lo que Cristo significa «El ungido». Exiten autores que remontan el origen de este signo hasta tiempos apostólicos y creen que debió nacer en oriente, cuando por primera vez los fieles adoptaron el nombre de cristiańos. Este origen explicaría por qué se compuso por letras griegas y no latinas (Martigny, 1894, 505). Sin duda fue el distíntivo de la Edad Constantiniana ya que tras la visión del emperador Constantino, este se fijó en el armamento defensivo del ejercito y se divulgó en el sistema monetario; su uso se introdujo en todas partes en una infinidad de formas que comprenden: el monograma aislado, colocado en el interior de círculos, coronas o palmas (victoria conseguida por el nombre de Cristo sobre todos sus enemigos), con una o dos palomas, con las letras «Alfa» y "Omega». En Oriente la letra "chi», fue sustituída por una simple línea transversal y este tipo parece que fue el único conocido en Egipto. En un determinado momento aparece cambiado el orden de las letras. Este hecho fue interpretado, en un primer momento, como un error del lapicida hasta que la Dra. Guarducci elaboró la teoria según la cual el nuevo orden de las letras tendría un caracter funerario. Esta idea es compartida por la Dra. Alonso Sánchez, sería el augurio de que el difunto pasaba, por Cristo, desde el fin al principio de la vida eterna (1982, p. 298). Este doble camino de Alfa a Omega y de Omega a Alfa, o lo que es lo mismo, de principio a fin y de fin a principio aparece repetidamente en el pensamiento de algunos padres de la iglesia (Clemente de Alejandría, Tertuliano y Paulino de Nola). En la Edad Media la letra «Rho" fue interpretada como la letra «Pi», por lo que el crismón se interpretó como el símbolo del Padre y Cristo. Se añadió la letra «S» de Espíritu 
dando lugar al crismón trinitario. Cuando el monograma aparece enmarcado en una corona de laurel sobre una cruz hablaríamos de «Anástasis» y simbolizaría la resurreción del Señor. A ambos lados de la cruz suelen figurarse dos soldados, los encargados de custodiar el sepulcro para evitar que los seguidores de Cristo robaran su cuerpo y anunciaran la resurreción de su maestro.

7. Cuadrado. Cirlot considera a este elemento como la expresión geométrica de la combinación y ordenación regular de cuatro elementos (1985, p. 156).

8. Damero. Toda superficie con recuadros, losanges o rectángulos alternantes simbolizan con la dualidad de elementos que presentan una extensión (tiempo) y por ello una relación con el destino (Cirlot, 1985, p. 163).

9. Delfín. Antes de hablar del simbolismo del delfín tenemos que tratar la figura del pez. Cirlot cree que el pez, en términos generales, es un ser psíquico, un movimento penetrante dotado de poder ascensional en lo inferior, es decir, lo inconsciente. Por la asimilación del mar y la Magna Mater algunos le consideraron sagrado. En los ritos asiáticos se adoraba a los peces y a los sacerdotes se les prohibía comer pescado. Al hijo de la diosa Atargatis, similar a Astarté se le daba el nombre de Ictis. Para algunos autores no solo tendría un simbolismo espiritual si no también fálico y de fecundidad (1985, p. 360). Este símbolo para ser comprendido requería una profunda iniciación cristiana. Fue el primero y más importante de los acrósticos cristianos. La iglesia primitiva lo adoptó como expresión del nombre de Cristo en sus dos naturalezas, de su procedencia divina y de su cualidad de salvador. En los primeros siglos se prefería, tal vez, por piedad, escribir en acróstico el nombre de Cristo. La antigua constumbre de las representaciones de animales simbólicos en los cementerios subterráneos, pasó a las iglesias y se conservó en ellas hasta el siglo xVI (Martigny, 1894, p. 62) Se origina de la denominación griega IXOYÇ cuyas letras son las iniciales de IOOOUS (Jesus) XPIOTOÇ (Cristo) ØEOV (de Dios) VIOÇ (Hijo) WT P (Salvador). Según los autores Kirschbaum, Junyent y Vives este acróstico se aprecia en las inscripciones de los últimos años del siglo II solo o comibinado con palomas, áncoras, panes, etc y desaparece en el siglo IV. Se reprodujo en infinidad de pequeños objetos: piedras talladas, anillos, sellos, vidrios de fondo dorado y pintura (Kirschbaum et alii, 1954, p. 282). El pez pudo simbolizar al propio cristiano cuando se le representa junto a otros peces y también pasó a ser símbolo eucarístico cuando aparece con figuras alusivas a este sacramento. 
En una inscripción de finales del siglo \| el obispo Abercio de Hierápolis (Frigia) afirmaba que «en todas partes la fe le condujo y le presentó por alimento un pez muy puro, salido de la única fuente, llevado por una virgen santa que ella daba de comer con sus amigos y que poseía el vino delicioso que lo administraba con el pan". Este significado se puede observar en la llamada cripta de Lucina en el cementerio subterráneo de San Calixto donde se ha figurado un pez al lado de una cesta llena de panes alusivos al milagro de la multiplicación (Kirschbaum, 1954, pp. 283-284). Entre las diferentes especies de peces que la antigüedad cristiana empleó figura con frecuencia el delfin. Fue considerado por los antiguos como emblema de la velocidad. Esta idea de celeridad ha podido inducir a los primeros cristianos a adoptarlo como emblema de la diligencia con tanta frecuencia repetida en las Sagradas Escrituras, para cumplir las obras de caridad y apresurarse a conseguir la prometida recompensa. También ha sido considerado como símbolo del amor y de la fidelidad conyugal. El delfin es uno de los símbolos más antiguos empleados en las sepulturas cristianas. El delfin puede aparecer figurado de varias maneras: 1.- Solo; 2.- Combinado con palomas, panes, etc; 3.- Enroscado a un tridente o bien situados en sentido vertical $u$ horizontal con respecto a este o a un ancla. En ambos casos se ha querido ver el signo de Cristo crucificado y la esperanza en Cristo; algunos autores ven en el tridente o en el ancla la representación de Cristo y en el delfín al cristiano (Martigny, 1894,258-259) y Cirlot cree que cuando el delfín aparece enroscado a un ancla significaría detención de la velocidad, es decir la prudencia (1985, p. 164).

10. Edículos, arcos y veneras. Se trata de temas de la iconografía arquitectónica que fueron transmitidos desde la antigüedad al mundo cristiano de la época visigoda. En el momento en que la jerarquía eclesiastica se hace potente y se erige en un poder paralelo al del emperador pasa a asumir los símbolos jerárquicos del Imperio romano (Cruz Villalón y Cerrillo, 1988, pp. 187-188). Se trata de signos visibles de un lenguaje establecido y asumido, despues que en una transmisión de siglos fueran utilizados por las más diversas culturas para expresar la idea de la superioridad del cosmos divino y de la autoridad del poder, conceptos equiparables en su categoria de sagrados (Cruz Villalón y Cerrillo, 1988, p. 202). El tema del edículo presenta una larga tradición, arranca desde el período helenístico y llega a alcanzar una amplia expansión durante el imperio romano (reflejado a través de los relieves de los sarcófagos). El tema tiene una continuidad clara en la escultura bizantina del siglo vı (Cruz Villalón, 1985, 273). El edículo dentro del campo de representación supo- 
ne la creación de un ambiente diferenciado en el palacio, en la vivienda privada, la basílica, templos u otros edificios de destino religioso. Se empleó para acoger personas de alto rango, escenas o símbolos. El edículo con bóveda proliferó en el arte romano sobre todo desde el Bajo Imperio en pinturas, relieves y artes menores con gran aceptación por parte del arte cristiano y bizantino. En un primer momento se empleó, por tanto, acogiendo las imágenes de dioses, sacerdotes, emperadores, cónsules, altos dignatarios o magistrados y dueños de la casa. En el mundo cristiano acogió las imágenes de Cristo, los apóstoles o elementos simbólicos como: crismón o crátera; guarda por tanto el carácter distintivo y especialmente sagrado. Adquiere propiedades simbólicas. En él se desarrollan las funciones esenciales del culto asociadas al principal elemento del mobiliario litúrgico: el altar. En él se entroniza al obispo, que asume en el orden religioso prerrogativas de la alta jerarquía política. En definitiva tanto arcos como edículos destacan la preeminencia de los temas que bajo ellos se acogen (Cruz Villalón, 1985, 284-285). Los autores antiguos denominan a esta zona «apsis», "exedra» o "conchula bematis». Estas palabras expresan una estructura arqueada o esférica, que imita a la bóveda celeste. San Jerónimo utiliza el término «ábside» siempre que se ocupa de esta parte de la iglesia. Otros autores como Procorpio, Pablo el Silenciario y San Paulino la llaman «conca», palabra derivada de la palabra griega KoYxr (concha) por su semejanza con la concha de ciertos moluscos (Martigny, 1894, 10). La concha ha sido elemento ligado al ritual de culto desde la Prehistoria. Fue un elemento simbólico y sagrado ligado al nacimiento de Afrodita o Venus. La concha aparece asociada a la cubierta del abside de la arquitectura romana, a veces con carácter ornamental, pero hay que tener en cuenta que en los origenes de su aplicación, la venera se encuentra en las grutas del culto a las diosas o encarnaciones femeninas y se inserta en la arquitectura del culto a Afrodita desde el helenismo. El nicho o arco con venera se convertirá en símbolo que cobija a personas venerables y en el cristianismo a Cristo, la virgen, los santos apoótoles o símbolos cristianos (Cruz Villálón y Cerrillo, 1988, 190-194). El arco de medio punto suele presentar un particular sistema de asiento sobre las dos columnas, éstas se desvían lateralmente cogiendo solo la mitad de la base del arco, quizá sea producto de la trasposición aislada de un solo arco desde una composición mayor de arquerias continuas donde dos arcos descansan sobre un mismo capitel o tal vez la imitación del tipo de arco que continua en dintel también conocido como «Dintel Arcuado». Este tipo de arco fue muy empleado en Roma y su uso pervivió durante el período visigodo. Se trata de un arco que se alza entre dos peristilos, fórmula 
de remoto origen oriental. Su presencia servía para denotar el carécter sagrado, bien de la persona que se representaba bajo él, privilegio que en Roma se reservaba al emperador entronizado o bien del lugar determinado de una arquitectura que quedaba diferenciada por esta representación. Así fue introducido en la arquitectura cristiana y bizantina, en arcos de entrada al "sanctuarium» y del mismo modo hace su aparición en la arquitectura visigoda en el arco de entrada al ábside de numerosas iglesias, donde la prolongación horizontal de las impostas sobre las que éste descansa, crea un efecto semejante al dintel arcuado (Cruz Villalón, 1985, 282-283).

11. Entrelazados. Con este nombre o con el de lacerias se entiende todo un amplio sector de ornamentalismo. Expresa sentido de ligazón indestructible de todo lo real y de imposibilidad de salir de ello. El entrelazado, por la vitalidad de la linea expresa el movimiento de la existencia en busca de espacios donde desarrollarse, formando laberintos y bosques inextricables aunque, en el arte, con frecuencia muy ordenados y geométricos (Cirlot, 1985, p. 184).

12. Espiga. Símbolo de la fecundidad y atributo solar. Simboliza la idea de germinación y crecimiento de desarrollo de cualquier posibilidad de vida. El haz de espigas ratifica este simbolismo (Cirlot, 1985, p. 195)

13. Estrella. Se obtiene por la intersección de dos cuadrados y suele aparecer inscrita en un círculo y adornada con roseta en el centro, combinación que debió constituir una fórmula repetida en la iconografia geométrica cristiana desde época muy antigua. Se comprueba su aparición en el siglo IV y pervive a lo largo del V, VI y VII. Este signo debió llevar implícito un simbolismo semejante al de Cristo o el Crismón. Según $M^{a}$ Cruz Villalón llegaría a España a través del norte de África. Una representación semejante la encontramos en la lauda sepulcral dedicada a Severina (Denia, Alicante). La difusión de este tema en la escultura visigoda fue muy escasa (Cruz Villalón, 1985, 322). Las estrellas pueden ser símbolos de la divinidad, de la eternidad del Salvador; indican al soberano dominio que su padre le ha dado en los cielos, así como también el reino eterno que ha conquistado él mismo por su pasión sobre el género humano (Martigny, 1894, 300). Para Cirlot como fulgor en la oscuridad, es símbolo del espíritu. Siguiendo a Bayley la estrella tiene muy pocas veces sentido singular y aparece casi siempre bajo el aspecto de multiplicidad. Simboliza entonces el ejercito espiritual luchando contra las tinieblas. Cree que su significado dependerá de su forma, número de puntas, disposición y color (1985, p. 199). 
14. Flecha. Arma de Apolo y Diana, significa la luz del supremo poder. Simboliza el rayo solar. Por su forma, tiene un sentido fálico innegable, en especial cuando aparece en emblemas contrapuesta a un símbolo del centro (Cirlot, 1985, p. 205).

15. Huellas de Sandalias. El símbolismo cristiano de las representaciones de pies es una adaptación más que hizo el cristianimo primitivo de temas paganos ${ }^{5}$. Rodríguez Oliva (1986-1987 y 1988) señala que las representaciones de pies calzados o desnudos se documentan en el mundo griego desde el siglo vi y en época helenística, pero sobre todo tuvieron gran desarollo en época romana. Se trata de placas con la representación de una pareja de pies o un par de parejas colocadas en sentido contrario; no se excluyen los pies escultóricos. En la península ibérica destaca la serie dedicada a Dea Caelestis y Némesis procedentes de Itálica y del templo de Isis en Baelo Claudia ${ }^{6}$. El autor, antes citado, nos habla de otros pies simbólicos, los relacionados con el culto a Serapis. En este caso suelen ser pies más o menos monumentales, sobremontados por una cabeza del dios. Recuerdan la historia contada por Herodoto $(I I, 91)$ según la cúal el dios egipcio local "Chemis" se manifestaba, a veces, por una sandalia de tamaño colosal presagio de un año de abundancia y buen agüero. Los pies escultóricos, las plantas de los pies y otras representaciones análogas eran la manera de hacer presente a los fieles la realidad de una teofanía; eran las huellas del dios y la más clara prueba de su presencia ${ }^{7}$. Para M. Guarducci la imagen simbólica del pie "expresa todo lo que un alma cristiana puede sentir delante de una tumba, tanto para el difunto, cuanto para los vivos. La planta pedis significaría la vida recorrida tras los pasos de Cristo en la virtud del sufrimiento por la justicia y el símbolo, así mismo, de aquel camino que el alma debe recorrer para salir del confinamiento del cuerpo y volver al señor» (Guarducci, M. 1944, pp. 305 y ss.).

5 Entre los temas paganos a los que se les otorga un simbolismo cristiano podemos mencionar: estaciones del año, pavo real, ave Fénix, Ulises, Orfeo, Eros y Psiché, etc.

6 En este sentido consultar los estudios de C. Fernández Chicarro, 1950 "Lápidas con huellas de pies y exvotos reproduciendo parejas de pies en el Museo Arqueológico de Sevilla", Revista de Archivos, Bibliotecas y Museos, 56, pp. 617-635; GarciA Y BeLlido, A. 1957: «El culto a la Dea Caelestis en la Península lbérica", Boletín de la Real Academia de la Historia, 140, pp. 451 y ss.; Idem, 1960: "Némesis y su culto en España", Boletín de la Real Academia de la Historia, 147, pp. 119 y ss.; CANTO DE GREGoRIO, A. 1984: «Les plaques votves avec plantae pedum d'Itálica: Un essai d'interpretation», Zeitschift für papyrologie und epigraphik, pp. 184-194, Bonn y 1985 La epigrafía romana en Itálica.

7 En este sentido podríamos interpretar las huellas de los pies de Cristo conservadas en la Iglesia de Quo Vadis (Roma). 
En el Bajo Imperio tuvo cierto uso la «Planta pedis» tal y como demuestra el hallazgo del fragmento cerámico en la necrópolis tardorromana de Tordox (Málaga), una pieza marmórea procedente de Málaga, en paradero actual desconocido. Al parecer presentaba una triple inscripción SEVER(u)S en pequeñas cartelas rectángulares y contenidas e lo que Fita consideró como la silueta de una sandalia; un sello de alfarero realizado en bronce de procedencia desconocida y conservado en la Biblioteca Nacional de Paris y las marcas de suelas claveteadas sobre ladrillos y tégulas documentadas en los ladrillos $\mathrm{n} .^{\circ} 36$ y 48 procedentes del Torreón de Gerena con paralelos en tegulas o ladrillos documentadas en las tumbas de San Miguel de Arroyo (Valladolid), dadas a conocer por el Profesor Palol y en las halladas en la necropólis de Sorde-L'Abaye. Los ejemplares de tégulas y ladrillos con huellas de sandalias son muy numerosos. EI Dr. Angel Fuentes cree que estas huellas pueden ser las marcas dejadas por los capataces encargados de supervisar la producción. Pertenecerían a un «status» social elevado, reflejado en el número de clavos que remachan la sandalia, cuanto mayor es el número de clavos mejor calidad y mayor precio tendría el calzado.

16. Marciano. Se han realizado diversas interpretaciones. Fita identifica a Marciano con un obispo de Sevilla que ocupó su sede episcopal entre finales del siglo iv comienzos del siglo $\vee(1908, p .353)$. Vives le considera obispo de Astigi (Ecija) entre los años 629-638 (1942, p. 139). El Padre Flórez en su obra España Sagrada señala que no hubo durante el período visigodo ningún Marciano que ocupara la silla episcopal de esta ciudad. Palol cree que ni la forma epigráfica de las letras ni el crismón que las acompaña participaian de los elementos artísticos frecuentes y normales del siglo VII (1967, pp. 265-267). Gómez Moreno, al igual que Fita, cree que fue obispo de la diocesis de Hispalis. Precisa la cronología en el año 420 (1966, p. 111). Especifica que en la localidad de Bujalance (Córdoba) existía un edificio construído con este tipo de ladrillo. Las ideas expuestas por Fita y Gómez Moreno estarían confirmadas por el Códice Emilianense (962) en él se especifica que en Sevilla existió un Marciano que ocupó la silla episcopal entre el 418-440 d.C.

17. Motivos vegetales. La flor es al mismo tiempo causa y efecto, la culminación y el comienzo, lo engendrado de la planta y el engendrador de la semilla de la que crece la planta. Su forma, el cáliz, la vincula física y etimologicamente con el caliz de la liturgia. La flor con frecuencia es el símbolo de la Vingen María (Baldock, 1992, 124). 
18. Octógono. Los ornamentos, construcciones arquitectónicas, composiciones diversas basadas en el octógono (en forma o en planta si se trata de edificio o de estructura como baptisterio, fuente, etc...); simbolizan la regeneración espiritual por ir el ocho unido a esta idea como interediario entre el cuadrado y el circulo. Así no es de extrañar que la mayoría de los baptisterios tengan forma octogonal. Con todo esto el doce es empleado en ocasiones en las pilas bautismales por ser símbolo de totalidad.

19. Palma. Este motivo geométrico se documenta, sobre todo, en el sur de la península. Es posible que este motivo proceda del norte de África (Villalón, 1985, p. 342). Símbolo de victoria. La primitiva iglesia la adoptó para expresar el triunfo del cristiano sobre la muerte por la resurreción. Suele aparecer acompañada del monograma constantiniano, en este caso significa que toda victoria del cristiano sobre sus enemigos se debe a este nombre y a este signo. Llegó a ser un adorno muy empleado hasta el punto que se hicieron moldes en barro cocido, empleados para estampar el grabado de una palma en la cal todavía fresca de los loculi. A partir de la Edad Media la palma se empleó como símbolo de martirio (Martigny, 1894, 614-615). Para Cirlot es también emblema de la victoria (1985, p. 353).

20. Paloma. Símbolo muy reproducido por los primeros cristianos. Imagen representada en toda clase de monumentos: pinturas, mosaicos, tumbas, lámparas, anillos, vasos de fondo dorado, etc. La paloma fue elegida por Dios para intervenir en todos los grandes misterios de su misericordia: diluvio, tres jóvenes en el horno de Babilonia, etc. Puede aparecer figurada en una infinidad de formas: 1.- Picoteando un racimo de uvas; 2.- Apoyada sobre el borde de un vaso apagando su sed (alusión al refrigerio eterno); 3.- Descansando sobre una cesta llena de racimos de uvas; 4.- Llevando en el pico una rama de olivo, de laurel, una palma o una corona. Puede ser interpretada de varias maneras: 1.- Imagen del alma viviente en la Paz Eterna; 2.- Mensajera de la paz. Interpretación que recoge Tertuliano «mensajera de la paz divina»; 3.- Símbolo del Espíritu Santo; 4.- Signo de la sencillez del cristiano: «Mirad, yo os envio como ovejas en medio de lobos; así que sed prudentes como las serpientes y sencillos como las palomas" (Mateo X,16); 5.- La iglesia la convirtió en símbolo del pudor, la inocencia, la humildad, la mansedumbre, de la caridad, de la contemplación y de la prudencia contra las asechanzas del enemigo. San Cipriano recoge en un pasaje la idea de mansedumbre «El Espiritu Santo ha venido bajo la forma de la paloma, animal sencillo y alegre sin amargura en la hiel»; 6.- Símbolo de Cristo a través de un texto de Prudencio 
en su obre Cathemerinon. Himno III. Ver. 116 «Tu eres para mí, oh Cristo, esta paloma poderosa a la cual abandona el pájaro repreto de sangre, es decir, el aguila que simboliza al demonio»; 9.- Fue empleada para designar a los apóstoles, como símbolo de sus virtudes; 10.- Designa a veces a los fieles recordando las virtudes que deben tener. Otras interpretaciones pueden ser: símbolo del martirio, de la resurreción, de la fidelidad conyugal, signo del dolor, de la ascensión de Jesucristo o de las almas de los mártires y de los fieles libertados de las trabas del cuerpo. Cirlot recoge la idea de que los esclavos consideraban que el alma tomaba forma de paloma después de la muerte. Cree que participa del simbolismo general de todo animal alado (espiritualidad y poder de sublimación). La religión cristiana, ateniendose a las Sagradas Escrituras, representa a la tercera persona de la Trinidad: El espíritu Santo, con forma de paloma.

De vez en cuando se representan pájaros encerrados en jaulas, en este caso se vinculan al alma humana aprisionada en las trabas corporales o a los mártires bajo la presión de la crueldad de los tiranos (Martigny, 1894, 612). Para Cirlot las aves simbolizan desde el Antiguo Egipto a las almas humanas. En general aves y pájaros como los ángeles son símbolos del pensamiento, de la imaginación y de la rapidez de las relaciones con el Espíritu. Conciernen al elemento aire y en consecuencia son espiritualidad. Este autor recoge un texto de Odón de Túsculo (Sermón $n .^{\circ} \mathrm{XCII}$ ) en el que expresa las siguientes ideas sobre las aves: «Unas son sencillas, como la paloma; otras astutas, como la perdiz. Unas llegan a la mano, como el halcón; otras huyen de ella, como la gallina. Unas aman convivir con los hombres, como la golondrina; otras la soledad y en el desierto como las tórtolas». Cirlot, considera que las aves de vuelo bajo simbolizan la actividad terrena; las de vuelo alto la pasión espiritual (1985, p. 91).

21. Perla. Ha sido asimilada al alma humana (Cirlot, 1985, p. 358).

22. Punto. Para Cirlot es en origen centro. Principio de la manifestación y de la emanación (1985, p. 377).

23. Rectángulo. Cirlot señala que es la forma geométrica más racional, segura y regular en todos los tiempos y lugares. Es la forma preferida por el hombre y la que él da a todos los espacios y objetos preparados para la vida. El cuadrado implica una dominación tensa e inspirada por el anhelo abstracto del poder, mientras que el círculo escapa al sentido terreno por su simbolismo celeste. Las formas menos regulares como el trapecio, son formas anormales, dolorosas y simbolizan el sufrimiento y la regularidad interior (1985, p. 383). 
24. Red. La red es la forma extrema de la laceria y del ligamento por ello está intimamente asociada a los símbolos de envolvimiento y la decoración (1985, p. 383).

25. Reloj de Arena. Símbolo de la inversión de relaciones entre el mundo superior e inferior (Cirlot, 1985, p. 384).

26. Rombos. El tema de los rombos en sus distíntas modalidades tienen un contacto claro con el arte geométrico del norte de África del siglo $\mathrm{V}$ d.C. En España la presencia de este motivo está restringida y centrada en: Córdoba, Sevilla y Mérida y a través de su influencia en Toledo (Villalón, 1985, p. 343).

27. Rosetas. Aparecen representadas de dos formas: a) Roseta de seis pétalos lanceolados radiales. Esta figuración está relacionada con las combinaciones dibujísticas a compás tan frecuentemente utilizadas en las composiciones ornamentales romanas, sobre todo en mosaicos donde adquirió una difusión generalizada; b) Roseta de doce pétalos lanceolados radiales. Variante recargada de las rosetas de seis pétalos. Procede de composiciones inspiradas en los esquemas musivarios. Se trata de un emblema símbolo ligado desde la más remota antigüedad a concepciones cósmicas y religiosas. Es uno de los signos que más dominio ha tenido en la historia de la representación geométrica (Cruz Villaló, 1985, 318-320). Tanto las rosetas como las estrellas son formas de representación que pertenecen a la categoria de los signos centrados, están trazados en torno a un punto central desde el que irradian sus partes componentes y del que equidistan las mismas al encontrarse la mayor parte de las veces inscritos en círculos. Existe una asociación simbólica con las ideas del equilibrio que se identifica con la armonia y el justo medio, equivalentes a la justicia y con las ideas del principio y fin de todas las cosas, imagen de la unidad primordial y en sentido inverso, es el centro al que han de retornar todas las cosas que han salido de él. Ambos signos geométricos aluden a la divinidad de modo abstracto (Cruz Villalón, 1985, 325-326).

28. Salvo. Según Marcos Pous la fórmula «Salvo» fue empleada en las inscripciones no cristianas del último tercio del siglo $\|$ y del primer tercio del siglo III; no obstante se difunde más a partir de la segunda mitad del siglo Iv continuando durante el $\vee$ y vi. Se documenta en singular $y$ en plural "Salvis". En el mundo pagano esta fórmula fue utilizada en relación a emperadores y desde finales del siglo iv en relación a papas y obispos. Siempre antecede al nombre propio de estos personajes. Parece 
que siempre se refirió a personajes vivientes expresando deseos de que se mantengan en buena salud, libres de peligros, etc. Cree que es una fórmula característica del occidente cristiano ya que está constatada en Roma (Lacio.Grottaferrata); Rávena e Hispania (Pous, 1981, pp. 64-65). En la elaboración de los moldes que contenían las inscripciones se tenían presentes las instrucciones impartidas por el «ordinator». El artesano disponía para realizar el letrero de unos moldes rectangulares realizados en materia plástica seguramente barro, donde se realizaría la inscripción en hueco o negativo a imprimir en cada canto; no existe por lo tanto un largo molde único que comprendiara todo el texto si no varios moldes, uno para cada canto del ladrillo. La sección de las letras no se realizaba a bisel sino redondeado o algo aplanado con estilete y trabajando a presión. Tras el período de secado los moldes serían cocidos (Pous, 1981, pp. 50-51).

29. Triángulos. Imagen geométrica del ternario, equivale en el simbolismo de los números al tres. En su posición normal, con el vértice hacia arriba también simboliza el fuego y el impulso ascendente de todo hacia la unidad superior, desde lo extenso (base) a lo intenso (vértice), imagen o punto irradiante. El triángulo invertido es un símbolo complejo y ambiguo. Signo del agua, expresa la involución por la dirección hacia abajo de su punta (fuerza) (Cirlot, 1985, p. 448). Este signo no es muy común en los monumentos cristianos. El investigador M. de Rossi le concedió alguna atención. Generalmente aparecen asociados al nombre del «Salvador», hecho que en nuestros ladrillos no se constata. En la iconografia moderna son considerados como símbolo de la trinidad (Martigny, 1984 , p. 819).

30. Tridente. Sobre el tridente o lanza de tres puntas se han establecido diversas interpretaciones: representación de los dientes de los monstruos marinos, forma derivada y cleformada de la cruz, alterada para darla agresividad. Todo instrumento, objeto o ser con tres miembros o tres partes donde normalmente pudiera bastar uno, simboliza la fuerza o posibilidad tiple (Cirlot, 1985, p. 448).

31. Zig-Zag. Ornato común en cualquier arte geomético; por su simplicidad de esquema Villalón lo relaciona con el arte geométrico de Tripolitania (Argelia) desarrollado entre los siglos $v$ y vı. La dispersión en España de este motivo está documentado, no solo en los ladrillos andaluces sino también en los relieves escultóicos del sur o de zonas periféricas como Tarragona (Villalón, 1985, 349). 


\section{SÍNTESIS FINAL}

La falta de restos arquitectónicos en la Bética cristiana está compensada por la riqueza y abundancia de elementos decorativos y de inscripciones tanto funerarias como las referentes a consagraciones de templos. Entre los elementos ornamentales se encuentran los ladrillos con decoración estampada, elementos característicos de esta región y localizados en la mayoría de los casos en el valle del Guadalquivir.

El origen de estas placas con decoración estampada lo encontramos en el África romana, especialmente en Túnez y zona oriental de Argélia, tal y como proponen Schlunk (1947); Palol (1956, 1961) y Schlunk y Hauschild (1978). Es posible que los ejemplares más antiguos documentados en la península procedieran de talleres norteafricanos y que posteriormente surgieran los talleres andaluces dirigidos por artístas procedentes de Túnez o de Argelia o por artesanos hispanos formados en talleres norteafricanos. No obstante entre los talleres africanos e hispanos siempre existieron relaciones muy estrechas ya que algunos ejemplares hispanos repiten casi literalmente los mismos motivos decorativos que los constatados en África.

Creemos que pudieron servir como ornamentación de edificios de carácter religioso y civil. Habrían sido empleados para la ornamentación de paredes (zócalos y frisos) y techos tal y como comprobamos en dos hallazgos. El primero mencionado por Schlunk y Hauschild (1978). En la excavación clandestina llevada a cabo en las proximidades de Osuna se encontraron numerosos ejemplares que se encontraban con la decoración boca-abajo sobre el pavimento de una casa. El segundo lo presentamos aquí por primera vez. El hallazgo se realizó en el Rubio (Sevilla). Los ladrillos se encontraban con la cara decorada hacia abajo y presentaban una capa de cal de $8 \mathrm{~cm}$. de espesor, sobre el pavimento de un edificio construído con paramentos realizados con piedras irregulares y ladrillos. Esta funcionalidad es defendida por Romero de Torres (1919); Fariña Couto (1939); Santos Gener (1958); Palol (1962, 1968); Schlunk y Hauschild (1978).

La temática es muy amplia. Nos encontramos con figuraciones que tienen sus paralelos en el arte romano y concretamente en los mosaicos pavimentales de las villas Bajo-Imperiales; temas cristianos de clara significación simbólica. Apenas se han documentado ejemplares decorados con escenas narrativas, tan frecuentes en el Norte de África. Podemos citar: 
1.- Hombre a caballo acompañado por un personaje masculino a pie. Procede de Aldea del Hoyo, al sur de Bélmez (Córdoba). Dado a conocer por Vives (1942); 2.- Escena de martirio presidida por la representación de Daniel entre los leones. Hallado en Lebrija (Sevilla). Publicado por Schlunk y Hauschild (1978) y 3.- Palmera con caballo a cada lado. Encontrado en Osuna y dada a conocer, como el ejemplar anterior, por Schlunk y Hauschild (1978). Por último se documentaron motivos realizados a bisel con paralelos en la ornamentación hispanovisigoda realizada en piedra. Algunos ejemplares presentan junto a los motivos ornamentales diversas inscripciones: Bracari vivas cum tuis, serie citada entre otros investigadores por Rada y Delgado (1876); Fita (1908); Gómez Moreno (1960) y Schlunk y Hauschild (1978). Documentados en Asta Regia, Alcalá del Rio, Ronda, etc.; Salvo Episcopo Marciano, ejemplares recogidos por Fita (1908); Vives (1942) y Gómez Moreno (1966). El primer autor cita los ladrillos hallados en el Cortijo de Barbuan (Morón de la Frontera). Por su parte Gómez Moreno transmite la noticia del hallazgo en Bujalance (Córdoba) de un edificio construído con este tipo de ladrillos; Salvo Ausentio, citados por Gómez Moreno (1966) y estudiados detalladamente por Marcos Pous (1981). Proceden de Espejo o Ategua (Córdoba); Amazonius, mencionados por Gómez Gómez (1987); Serrano Carrillo (1995) y Stylow (1995, II, 7.194 a, b, c y d). Fueron documentados en varios lugares del entorno de Bujalance y Cañete de las Torres (Córdoba); Mixal, citados por Schlunk y Hauschild (1978); Barroso Cabrera y Morín de Pablos (1993 y 1995). Los ejemplares fueron recogidos en el Cortijo de la Vizcondesa (Ronda, Málaga); Lententur celi et exultet Terra Omn, fue citado por Vives (1942) como procedente de Villaviciosa de Córdoba. A pesar de que este autor identifica la frase con el Salmo $n .^{\circ} 95$, en realiadad se trata de un párrafo recogido en el Salmo . $^{\circ} 96$ titulado Alabanzas a Yahveh, rey de toda la tierra. El texto dice lo siguiente: «Cantas a Yahveh un cántico nuevo/ cantad a Yahveh, oh tierra toda/cantad a Yahveh, bendecid su nombre/ albriciad su salvación día tras día/ su gloria referid entre las gentes/ entre todos los pueblos sus portentos/porque grande es Yahveh y muy digno de loa/ es temible sobre todos los dioses/ porque todos los dioses de los pueblos son ídolos/mientras Yahveh los cielos ha hecho/ Majestad y esplendor hay ante él/fortaleza y pompa en su santuario/tributad a Yahveh oh familias de pueblos/tributad a Yahveh gloria y potencia; tributad a Yahveh la gloria de su nombre/aportad oblación y venid a sus atrios/adorad a Yahveh en sacra majestad/templad en su presencia, oh tierra toda/decid por las naciones Yahveh es rey/y ha asegurado el orbe para que no vacile/ El juzga a los pueblos con equidad/ 
Alegrense los cielos y que la tierra exulte/retumbe el mar y cuanto lo llena. Jubile el campo y cuanto en él existe/aclamen a la vez los árboles todos del bosque/ ante Yahveh, pues vive/pues viene a juzgar la tierra; juzgará al mundo con justicia/ y a los pueblos en su fidelidad». Gómez Moreno (1966) cita otras inscripciones: Marciana vivas in Christo, Spes in Deo, Camilla in Deo decedit e vita, Felix asella, Lupicus vivit, Elia Elina cum filis gaudet, Sabule Salva y Vivas in Deo. Las dos primeras inscripciones y la última citadas en 1966 fueron recogidas posteriormente por Stylow en el año 1995 (CIL II, 7,195a y b).

No se puede establecer un cuadro evolutivo seguro debido a la falta de excavaciones sistemáticas con hallazgos de ladrillos in situ y a la falta de textos literarios que hagan referencia a ellos. La única manera de clasificación cronológica es acudir a comparaciones estilísticas. Los ejemplares aquí presentados podrían englobarse entre los siglo IV al VII tal y como proponen Schlunk (1947) y Palol (1961) aunque este segundo autor estima que podrían haberse mantenido hasta el inicio del siglo vIII e incluso su uso podría constatarse en época musulmana, aunque, con otro espíritu.

\section{BIBLIOGRAFÍA}

Alonso SÁnCHEZ, Ma A. 1982: "Crismones con Omega-Alfa en España", I/ Reunió d'Arqueologia Paleocristiana Hispánica, IX Symposium de Prehistoria i Arqueologia Peninsular, pp. 297-302, Barcelona (2-5 Noviembre, Montserrat).

BALDOCK, J. 1992: El simbolismo cristiano. Qué es, cúal es su finalidad y cómo desentrañar su lenguaje, Madrid.

BALMELLE, C. et all. 1985: Le décor Géometrique de La mosaïque romaine. Répertoire graphique et descriptif descompositions Linéaires et isoptopes, París.

BARRAL, 1.; AALTET, X. 1994: "L' escultura arquitectónica i decorativa en els monuments religiosos de l' Antiguitat tardana Hiapana", III Reunió d'Arqueologia Cristiana Hispanica. Maó 12-17 de setembre (1988), pp. 41-46.

Barroso Cabrera, R., y Morin de Pablos, J. 1993: El árbol de la vida. Un estudio de iconografía visigoda: San Pedro de la Nave y Quintanilla de las Viñas, Madrid.

Barroso Cabrera, R., y Morin de Pablos, J. 1994: "El nicho placa de Salamanca del Museo Arqueológico Nacional y otros testimonios arqueologícos del culto a San Miguel en época visigoda", Zephyrus, XLVI, Salamanca.

Barroso Cabrera, R., y Morin de Pablos, J. 1995: El relieve de Montanchez. lconografía y pensamiento. Almud. Reflexiones sobre el Patrimonio Histórico y Medio Ambiente, julioseptiembre, año $11, n .^{\circ} 6$ Extraordinario, Madrid.

CABezón, A. 1964: «Epigrafía Tuccitana», Archivo Español de Arqueología,XXXVII, $1{ }^{\circ}$ y 2. semestre, n. ${ }^{\circ} 109$ y 110 , pp. 106-155, Madrid.

CAmps Cazorla, E. 1940: «El arte hispanovisigodo", Historia de España dirigida por Ramón Menéndez Pidal. Tomo III. España Visigoda (414-711 d.c.), pp. 435-608, Madrid.

Canto de Gregorio, A. 1984: «Les plaques votives avec plantae pedum d'Itálica: Un essai d' interpretation», Zeitschrift für Papyrologie und epigraphik, pp. 183-194, Bonn. 
Canto de Gregorio, A. 1985: La epigrafía romana en Itálica, Madrid.

Corpus Inscriptionum Latinarum. Consilio et Auctoritate. Academie Scientiarum Berolinensis et Brandenburgensis. Volumen secundum. Inscriptiones Hispaniae Latinae. Editio Altera Pars VII Conventus Cordubensis CIL II 2/7. Edidit Armin U. Stylow Adiuvantibus Cristóbal Gónzalez Román et Géza Alföldy MCMXCV.

CIRLOT, J.E. 1985: Diccionario de Símbolos, Barcelona.

CRUz VILLALÓN, Ma . 1985: Mérida visigoda. La escultura arquitectónica y litúrgica, Badajoz.

Crüz Villalón, M. à y CerRillo Martín de CÁCERES, E. 1988: "La iconografía arquitectónica desde la antigüedad a la época visigoda: ábsides, nichos, veneras y arcos», Anas, 1, pp. 187-203, Mérida.

Esteve Guerrero, M. 1941: "Contribución al conocimiento de Asta Regia", Actas de la Sociedad Española de Antropología, Etnología y Prehistoria. Atlantis, XVI, pp. 386-401, Madrid.

FARIÑA CoUTO, L. 1939-1049: «Notas sobre motivos ornamentales visigóticos. El ladrillo con relieves", Boletín del Seminario de Arte y Arqueología, VI, pp. 205 y ss., Valladolid.

FERnÁndez ChIACARRO, C. 1950: «Lápidas votivas con huellas de pies y exvotos reproduciendo parejas de pies del Museo Arqueológico de Sevilla», Revista de Archivos, Bibliotecas y Museos, 56, pp. 617-635, Madrid.

FERRANDIS, J. 1940: «Artes decorativas visigodas», Historia de España dirigida por Ramón Menéndez Pidal. Tomo III. España Visigoda (414-711 d.c.), pp. 609-666, Madrid.

FlITA, F. 1908: «Inscripciones romanas y visigóticas de Tarifa, Ronda y Morón de la Frontera», Boletín de la Real Academia de la Historia, 53, pp. 344-353, Madrid.

García y Bellido, A. 1957: «El culto a Dea Caelestis en la Península lbérica», Boletín de la Real Academia de la Historia, 140, pp. 451 y ss.

GARCía Y Bellido, A. 1960: «Némesis y su culto en España», Boletín de la Real Academia de la Historia, 147, pp. 119 y ss.

GómEZ-GómEZ, A. 1987: «Prospección arqueológica superficial en los términos municipales de Baena, Castro del Río, Espejo y Córdoba», Anuario Arqueológico de Andalucia, pp. 107. 114, Sevilla.

Gómez Moneno, M. 1966: «Primicias del arte cristiano Español», Archivo Español de Arte, 39, pp. 101-139, Madrid.

González Román, C., y Mangas Manjarrés, J. 1991: Corpus de Inscripciones latinas de Andalucía. Volumen III. Jaén. Tomo II, Sevilla.

GuARDUCCI, M. 1944: "Le impronte del Quo Vadis e monumenti affini, figurati ed epigrafici", RPAA, 19, pp. 305 y ss.

Hispania Antiqua Epigraphica, 1957-1960, n. ${ }^{\circ} 8-11$, p. 42, Madrid.

HUBNER, A. 1869: Inscriptiones Hispaniae Latinae. Volumen secundum.

HUBNER, A. 1892: Corpus Inscriptionum Hispaniae Latinorum. Supplementum.

KIRSChBAUm; JUNYENT y Vives, 1954: La tumba de San Pedro y las catacumbas romanas, Biblioteca de Autores Cristianos, Madrid.

LOZA AZUAGA, Mㄹ. L. 1991-1992: «Tipología y catálago de las placas cerámicas decoradas a molde de época tardorromana y visigoda conservadas en el Museo de Málaga", Mainake, XIII-XIV, pp. 252-265, Málaga.

Marcos Pous, M. 1981: «Letreros de ladrillos cordobeses con la fórmula cristiana antigua Salvo Ausentio", Corduba, 11, pp. 49-68, Córdoba.

MARTIGNY 1894: Diccionario de Antigüedades cristianas, Madrid.

MARTín GÓmEZ, C. 1982: «Placas decoradas de época paleocristiana y visigoda, con inscripción, del Museo Arqueológico Provincial de Sevilla», Museos, 1, pp. 37-43, Madrid.

Oliver y HuRtado, J. 1886: Munda Pompeyana. Dictamen de D. Aureliano Fernández Guerra y Orbe. Viaje arqueológico, Madrid.

PALOL, P. 1956: «Esencia del arte hispánico de época visigoda: romanismo y germanismo», Settimane di Studio del Centro Italiano di Studi sull' Arte Medioevo. III. I Goti in Occidente. Problemi, pp. 65-126, 20 marzo - 5 abril 1955, Spoleto.

PALOL, P. 1961: «Placas decoradas paleocristianas y visigodas», Scritti d'istoria dell Arte in onore Mario Salmi, pp. 131 y ss, Roma. 
PALOL, P. 1962: «A propósito de las placas de cerámica decoradas hispanovisigodas», Atti dell' Ottavo Congresso di Studi sull' arte Alto Medioevo. stucchi e mosaici Alto Medievali, Vol. I, pp. 300-302, Milán.

PALOL, P. 1967: "La decoración escultórica en cerámica de época paleocristiana y visigoda», Arqueología Cristiana de la España Romana. Siglos N-VI, pp. 255-272, Madrid-Valladolid.

PALOL, P. 1968: Arte hispánico de la época visigoda, Barcelona.

PALOL, P. 1968 «Herencia romana en el arte ornamental de tiempos visigodos», España en la crisis del arte europeo. Coloquios celebrados en conmemoración de los XXV años de la fundación del CSIC, pp. 51-59, Madrid.

PALOL, P. 1969: «La necrópolis de San Miguel de Arroyo y los broches hispanorromanos del siglo IV», Boletín del Seminario de Arte y Arqueología, XXXV, pp. 93 y ss., Valladolid.

PALOL, P. 1987: "La escultura paleocristiana en Hispania", XXXIV Corso di Cultura sull' arte Ravennate e Bizantina. Seminario Internazionale di Studi su Archeologia e Arte nella Spagna tardorromana, visigota e mozarabica, pp. 301-305, 4-11 Aprile 1987, Ravenna.

PALOL, P., y RIPOLL, G. 1988: Los Godos en el occidente europeo, Madrid.

RADA Y DELGADO, J. de Dios 1876: "Ladrillos sepulcrales cristianos que se conservan en el Museo Arqueológico Nacional», Museo Español de Antigüedades, 7, pp. 593 y ss.

Ramirez Arellano, R. 1983: Inventario catálogo Histórico Artístico de Córdoba, Córdoba.

ReCio, A., y Fernández Chicarro, C. 1959: “La colección de antigüedades arqueológicas del padre Fr. Alejandro Recio", Boletín del Instituto de Estudios Gienenses, 20, año VI, abriljunio, pp. 121-159, Jaén.

Rodriguez Berlanga, M. 1909: Catálogo del Museo Loringiano, Málaga.

Rodriguez OLiva, P. 1986-1987 «Spes in Deo. A propósito de una marca impresa sobre un fragmento cerámico hallado en la necrópolis romana del Faro de Tordox (Málaga)", Mainake, VIII-IX, pp. 215-224, Málaga.

Rodriguez Oliva, P. 1988: «Spes in Deo (II)», Mainake, X, pp. 181-183, Málaga.

Romero de TORRES, E. 1911: “Montilla romana y visigoda. Nuevos descubrimientos», Boletín de la Real Academia de la Historia, 58, pp. 75-81, Madrid.

ROMERO DE TORRES, E. 1919: "Nuevos descubrimientos arqueológicos en la provincia de Córdoba», Boletín de la Real Academia de la Historia, LXXXIV, pp. 135-140, Madrid.

SANTOS GENER, S. de los 1958: «Las artes en Córdoba durante la dominación de los pueblos germánicos", Boletín de la Real Academia de Córdoba de Ciencias, Bellas Letras y Nobles Artes, año XXIX, n. ${ }^{\circ} 77$, enero-junio, Córdoba.

SCHLUNK, H. 1944: «El arte decorativo visigodo», Boletín Bibliográfico, año XII. n. ${ }^{\circ}$ 1-2 enerojunio, Instituto Arqueológico Alemán, pp. 14-34, Madrid.

SCHLUNK, H. 1947: "Arte visigodo. Arte bizantino", Ars Hispaniae. Historia Universal del Arte Hispánico, pp. 227-416, Madrid.

SCHLUNK, H., y HAUSCHILD, TH. 1978: Hispania Antiquae. Die Denkmäler der frühchritlichen und wesgotischen Zeit, Mainz.

Serrano Carrillo, J. 1995: Guía del Museo Histórico Municipal de Cañete de las Torres (Córdoba). Excma. Diputación Provincial de Córdoba e llustre Ayuntamiento de Cañete de las Torres, Córdoba.

Serrano Ramos, E. 1973: Materiales de Manguarra y San José (Cártama)", Jábega, 1, Primer trimestre, pp. 67-70, Málaga.

Serrano Ramos, E., y Atencla Pérez, R. 1981: Inscripciones latinas del Museo de Málaga, Málaga.

Serrano Ramos, E., y LuQue Moraño, A. 1976: «Memoria de las excavaciones de Manguarra y San José (Cártama, Málaga)», Noticiario Arqueológico Hispánico. Arqueología, 4, pp. 489-546, Madrid.

Serrano Ramos, E., y LuQue Moraño, A. 1980: "Memoria de la segunda campaña de excavaciones en la villa romana de Manguarra y San José, Cártama (Málaga)", Noticiario Arqueológico Hispánico, 8, pp. 253-396, Madrid.

SIRET, L. 1906: Villaricos y Herrerias. Antigüedades púnicas, romanas, visigóticas y árabes. Memoria descriptiva e histórica, Madrid.

PUERTAS, R. 1986-1987: "Los hallazgos arqueológicos de Torreblanca del sol (Fuengirola)», Mainake, VIII-IX, pp. 145-200, Málaga. 